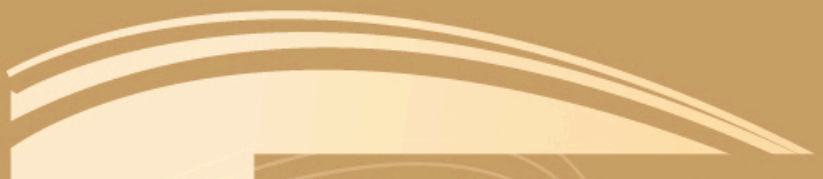

Este proyecto viene a llenar la aspiración institucional de relacionar el desenvolvimiento de la ciencia contable al paso de la historia nacional, y en particular con los ideales bolivarianos de construir una gran República de vocación continental. La historiografía sobre la dinámica fiscal de la "Gran Colombia" se centra en el análisis de cómo las medidas legislativas se vieron reflejadas en periodos de coyuntura. De esta manera se evidencia la aparición de tres vertientes, la primera de ellas de orden jurídico, la siguiente enmarcada en la historia económica centrada en el análisis de los ciclos, y otra preocupada por el pensamiento económico. Realmente, existe un défici frente al análisis de la planificación y el control contable como política de Estado. Las fuentes utilizadas para la elaboración de este enfoque son tomadas generalmente de las Memorias de Hacienda y el Tesoro, y de los libros de numerosos académicos contemporáneos que se mencionan en las referencias bibliográficas al final de este documento.

La meta principal de este proyecto es proporcionar evidencias empíricas sobre la relevancia (pertinencia) de la información contable oportuna para evaluar la estabilidad financiera del Proyecto Republicano de la Gran Colombia, vigente durante $1819-1830$ y comprobar la capacidad del cuerpo administrativo de turno de entonces, para anticipar si los cambios en la opinión del revisor de cuentas (el auditor de hoy) podían ser interpretados como señales de estrés financiero.

Además del aporte de nuevos conocimientos sobre nuestra historia, se espera que a través de este libro que describe los incumplimientos y descuidos de las autoridades encargadas de regir los destinos del Proyecto Republicano de la Gran Colombia y de otras publicaciones surgidas de esta investigación sobre la función preventiva del control interno, ayude a las nuevas generaciones a suspender el imperante lenguaje polarizador que muchas veces utilizamos y que nos cubre como una sombra día a día, oscureciendo y aturdiendo las tranquilas mentes de todos los colombianos. En épocas como la del presente proyecto, quisiéramos que una auditoria reconstructiva fuese capaz de derrotar ese inconveniente contexto de empantanamiento social que persiste en ver el atraso socioeconómico actual del país como una condenación ineludible y dirigida contra el alma de nuestros pueblos.

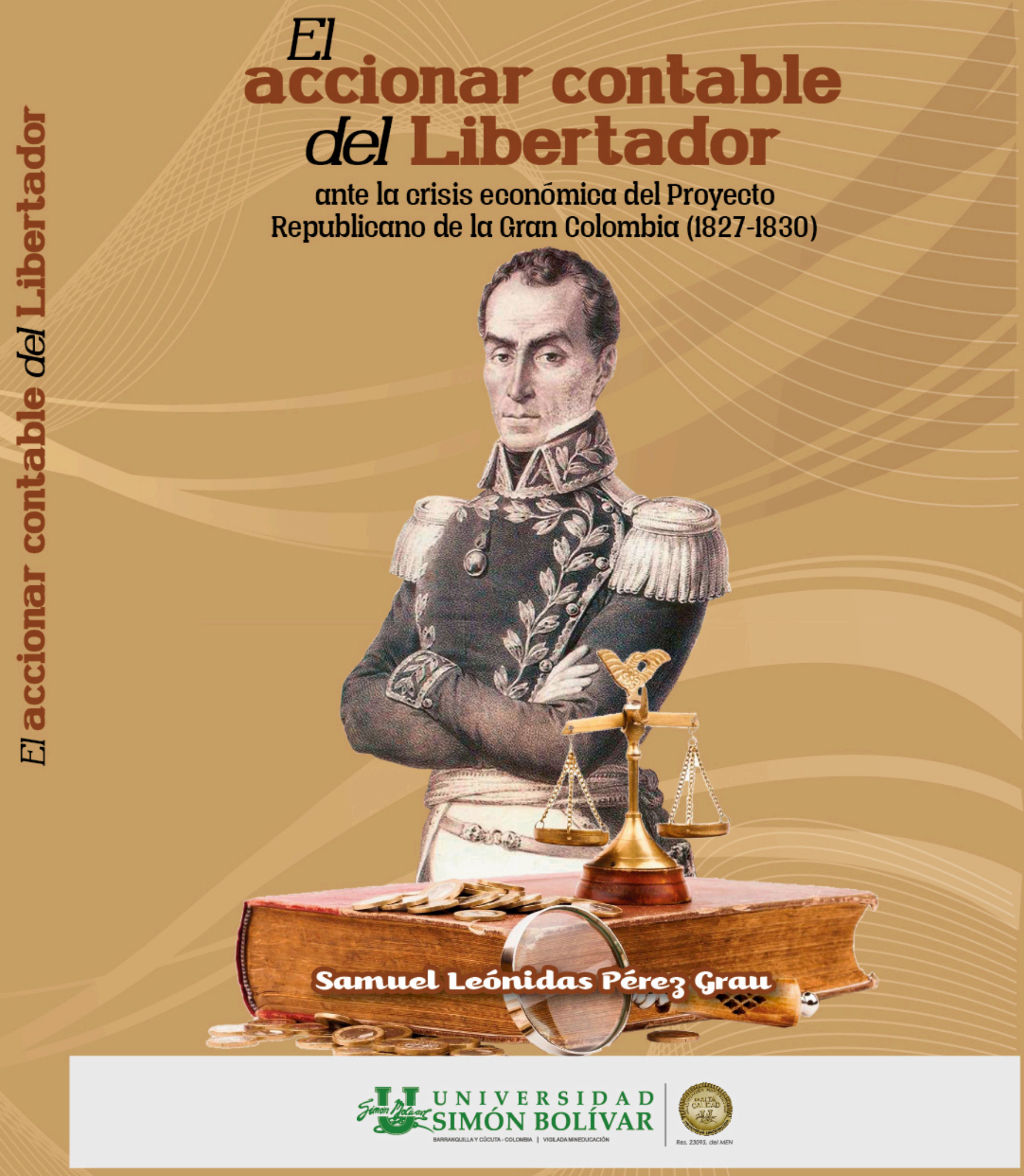




\section{accionar contable del Libertador \\ ante la crisis económica del proyecto republicano de la Gran Colombia (1827-1830)}


BARRANQUILLA Y CÚCUTA - COLOMBIA

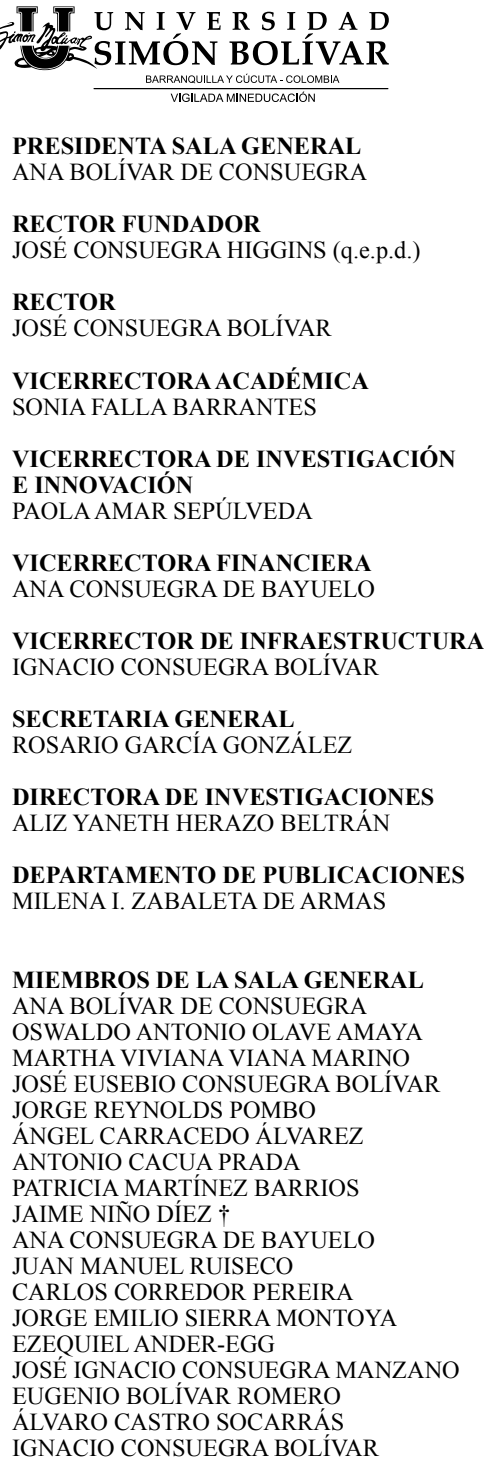

\section{El accionar contable del Libertador}

ante la crisis económica del proyecto republicano de la Gran Colombia (1827-1830)

Samuel Leónidas Pérez Graul 


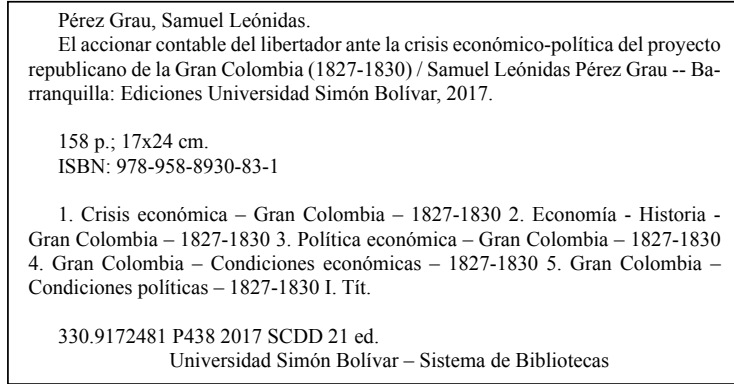

EL ACCIONAR CONTABLE DEL LIBERTADOR ANTE

LA CRISIS ECONOMICO-POLITICA DEL PROYECTO

REPUBLICANO DE LA GRAN COLOMBIA (1827-1830)

○ Samuel Leónidas Pérez Gra

Grupo de Investigación Pensamiento contable y gestión internacional Director Milena Zabaleta de Armas

Proceso de arbitraje doble ciego

Evaluación de propuesta de obra: Agosto 2016

Evaluación de contenidos: Octubre 2016

Correcciones de autor: Noviembre 2016
Aprobación: Enero 2017

Impreso en Barranquilla, Colombia. Depósito legal según el Decreto 460 de 1995 . El Fondo
Editorial Ediciones Universidad Simón Bolivar se adhiere a la filosoffia del acceso abierto y permite

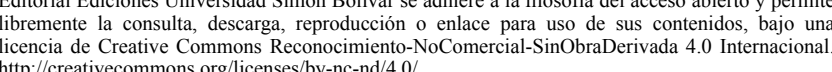

\section{(c) (i) $(9)$}

OEdiciones Universidad Simón Bolivar

http://publicaciones.unisimonbolivar.edu.co/edicionesUSB/

dptopublicaciones@unisimonbolivar.edu.co

Barranquilla - Cúcuta

Producción Editoria

Editorial Mejoras
Calle 58 No. $70-30$

www.editorialmejorass.co

Marzo de 2017

Made in Colombia

\section{Dedicatoria}

A la memoria del insigne humanista y fundador de la Universidad Simón Bolívar. José Consuegra Higgins, quien siempre consideró a la Contabilidad como Ciencia Social que tiene el compromiso de visualizar los entes empresariales de modo orgánico en su contexto, en el cual la obtención de resultados pecuniarios no puede ser visto como el único elemento de aferencia de su efectividad. 


\section{Contenido}

INTRODUCCIÓN.

Estado del arte

Metodología

Resultados

El transcurso económico-político

\section{LAS DIFICULTADES}

\section{DEL ENTORNO E INTERNAS}

Las dificultades del entorno

Los indicadores de crecimiento económico

Los cambios en los niveles de precio

Los cambios culturales y sociales

Los cambios de gobierno

Las dificultades internas

Pérdida de la productividad

Baja cultura empresarial.

Los primeros síntomas de dificultad fiscal

Incremento de los gastos financieros 
Venta del inmovilizado necesario

El escenario de riesgo

El empréstito de 1824

Los gastos de la guerra

La derogación de la contribución directa.

La flexibilización de los derechos aduaneros

La fundación de la deuda pública.

El escenario de crisis

Presupuesto de ingresos del año de 1826.

Presupuesto de gastos del año 1826

Presupuesto de gastos del año 1827

45

52

54

\section{LAS SOLUCIONES QUE NO SE IMPLEMENTARON}

\section{CONCLUSIONES}

El fracaso del proyecto republicano.................................. 93

Los hechos materia de información y control contable. 95 Los objetivos y prioridades de información y control.... 100

La regulación contable

REFERENCIAS BIBLIOGRÁFICAS

\section{ANEXOS}

Anexo I: EI transcurso histórico

Período centralista por la campaña

libertadora (I819-1824)

La Revolución Liberal Española de 1820
La independencia del Perú

130

Período de ordenación fiscal federalista (I824-1826).

Las reformas fiscales entre 1824 y 1826

Período de afirmación de la autonomía

regional 1826-1830.

El pronunciamiento de Valencia

Anexo 2 Ingresos y Egresos Totales de la RepÚblica de Colombia (1819-1830)

Anexo 3: Ingresos y Egresos de la Región Central de la República de Colombia (I 8 | 9- | 830)

Anexo 4: Ingresos y Egresos de la Región Sur de la República de Colombia (1819-1830)

Anexo 5: Ingresos y Egresos de la Región Norte de la República de Colombia ( 18 | 9- | 830).

Anexo 6: Ingresos y Egresos de la Región Oriental de la República de Colombia (1819-1830). 


\section{Prólogo}

Con justificada razón la figura que más ha concitado el interés de las Ciencias Humanas por hacer de su vida y obra un objeto de estudio apetecido, es -sin lugar a equívocos- la de Simón Bolívar. En las bibliotecas y librerías de América, sobre todo la de los países bolivarianos se cuentan por centenares las biografías y los estudios temáticos sobre El Libertador.

Como bien sabemos, la obra, el pensamiento y la práctica política de Bolívar ha sido estudiada y reclamada por diferentes posturas políticas e ideológicas, por ello no es de extrañar que liberales, conservadores, de derecha o de izquierda hagan de Bolívar uno de sus soportes filosóficos o lo erijan como ícono en sus mitos fundacionales.

Es de tal magnitud la figura de Bolívar, que en una rápida revisión bibliográfica son evidentes múltiples miradas y percepciones vertidas sobre él: Bolívar político, estratega militar, pedagogo, periodista, filósofo, etc. Pero también se pueden identificar vacíos que las ciencias sociales deben llenar sobre él. Tal es el caso del texto motivo de este libro. Indudablemente faltaba un estudio que diera cuenta de esa faceta ignorada del Libertador: La de contador, planificador y ordenador de las finanzas públicas, sobre todo en épocas de crisis como fue la que se vivió en la post-independencia, por causa de la dislocación y estancamiento de todos los procesos, ocasionados por la dinámica de la confrontación bélica.

En términos generales, este libro ofrece una explicación de las prin- 
cipales coyunturas determinantes del fracaso republicano del proyecto de la Gran Colombia: "Para la eficacia de la función de planificación y control de dicho proyecto, era fundamental la intervención del Ejecutivo, considerando los objetivos de control interno de cada ciclo y, los riesgos que se corren, al no lograrse. Debe ser reconocido sin embargo, que había carencia del personal apropiado y era casi imposible desarrollar un control centralizado pues la rutina administrativa había sido rota por causa de la guerra".

El autor infiere cómo "las políticas administrativas adoptadas por el Ejecutivo grancolombiano no fueron cuidadosamente observadas, para descubrir cualquier desviación en la práctica del sistema establecido. Muchos fraudes y desfalcos fueron facilitados por la continua violación, o el completo abandono de procedimientos que teóricamente son instituidos para impedir tales actos dolosos. Y peor aún, el proceso de comunicar las debilidades y oportunidades de mejoramiento de los sistemas de control, si es que los hubo, no estuvo dirigido hacia quienes eran los responsables de operarlos, para que estos asumieran las acciones necesarias".

Es preciso señalar que esta obra reivindica el esfuerzo desplegado por El Libertador en pleno escenario de la crisis económica-política, a finales de 1826, cuando reasume sus funciones de Presidente de la República con todo el rigor posible, tratando de superar el efecto paralizante de la deuda por la inevitable destrucción de valor que cada vez más acumulaba saldo negativo para las finanzas públicas; sin embargo, quizás porque lo decidió muy tarde, Bolívar nada pudo lograr para la salvación del proyecto republicano de la Gran Colombia, de vocación continental con que había soñado, cuyo fracaso se plasma desde el 20 de marzo de 1830 cuando la Asamblea Constituyente denominada Congreso Admirable no logró concretar la unión de las regiones en torno al mundo de Bogotá.
En igual sentido al de la presentación de la importante lista de referencias bibliográficas que hace el autor en su obra, es pertinente aquí, relievar la existencia del Museo Bibliográfico Bolivariano de la Universidad Simón Bolívar, único en América y, que con contadas excepciones, preserva y cuenta con toda la producción bibliográfica que sobre el Libertador se ha generado en el ámbito universal. Esta Universidad -haciendo honor a su nombre- no solo ha hecho del ideario bolivariano su presupuesto ideológico básico, sino que en términos curriculares ha implementado la Cátedra Bolivariana como eje transversal que apuntala todo el proyecto pedagógico.

Finalmente debo expresar mis agradecimientos por la deferencia que tuvo el autor de esta obra, el ilustre contador público Samuel Pérez-Grau, al escoger mi nombre para prologar tan importante obra histórica. Ante todo, acepté tan honrosa designación como el mínimo respaldo que un historiador de profesión debe brindar a todos aquellos profesionales que aunque no son discípulos directos de Clío realizan ingentes esfuerzos para investigar los hechos históricos acaecidos dentro de sus disciplinas, contribuyendo así al desarrollo de la Historia Económica nacional.

Sin lugar a dudas, es admirable el trabajo realizado por el profesor Pérez-Grau, por cuanto la ciencia de la contabilidad per se constituye una extraña pieza entre los temas de la historia, pero también por su intento de señalar el sorprendente perfil de El Libertador tras su accionar contable-administrativo intentando re-direccionar nuestra temprana historia republicana.

Dolcey Romero Jaramillo Doctor en Historia, Universidad de Huelva 


\section{Introducción}

Este libro es producto de investigación del Grupo Pensamiento Contable y Gestión Internacional de la Universidad Simón Bolívar. El proyecto responde a una larga expectativa del autor, profesor en el Programa de Contaduría Pública, para develar la forma de hacer contabilidad en el sistema administrativo del proyecto republicano de la Gran Colombia y, el estilo ejecutor y controlador ejercido por el Libertador como Presidente de la República.

La idea que guía este estudio ha sido poder establecer: ¿Cuál fue el modelo de planificación contable aplicado por las autoridades republicanas grancolombianas?, ¿cómo eran los elementos de Control interno en la Gran Colombia?, ¿cómo funcionaba la Auditoría interna en la República de Colombia de I819 a 1830?

La metodología investigativa aplicada en este proyecto es la de la investigación histórica educativa, bajo la cual fueron cumplidos todos los criterios y características establecidas en las normas institucionales sobre investigaciones cualitativas, analíticas y sistemáticas.

Este libro describe en un texto unitario las condiciones organizacionales en que se desarrolló el proyecto republicano. Comienza con una exploración del transcurso económico-político para mostrar situaciones sobre las que urgía tomar decisiones, tanto capaces de re-direccionar el comportamiento de la Hacienda como exaltadoras del estado de ánimo de los funcionarios encargados de administrar 
la República,y termina con una descripción del Fracaso del Proyecto Republicano que revela las incidencias de las acciones desesperadas del Libertador para encontrar un punto de equilibrio entre costes e ingresos que permitiera retrasar así, la transferencia del control republicano a manos de los acreedores.

El libro se acompaña del Anexo I intitulado El Transcurso Histórico, para lectores no historiadores, que relata acontecimientos e incidentes sobre la conformación de coyunturas determinantes de situaciones de riesgo, $y$ de otros cinco anexos, que presentan estadísticas sobre la evolución fiscal en que se desenvuelve el proyecto republicano.

\section{ESTADO DEL ARTE}

En la historiografía fiscal colombiana, el rol del estadista es más identificado con la ciencia política y menos con las responsabilidades de naturaleza económica. Son muchos los estudios conocidos sobre la Gran Colombia, sin embargo, casi todos hacen énfasis en un enfoque historiográfico y poco tratan el papel administrativo desempeñado por sus autoridades.

Para hacer un poco de justicia, vale aquí destacar como los más entrados en el estudio del pensamiento económico, los estudios de Juan Camilo Restrepo sobre la Hacienda Pública en la Constitución de 182I, los de Óscar Rodríguez y Decsi Arévalo sobre Gremios, reformas tributarias y administración de impuestos, y los de José Joaquín Pinto sobre las Finanzas de la Gran Colombia, enlistados todos como referencias bibliográficas al final de la obra. De ahí la gran pertinencia de la presente investigación para adentrarse en los pormenores de la administración de un proyecto que no tenía por qué fracasar.

\section{METODOLOGÍA}

El propósito de esta investigación es reunir evidencia suficiente para analizar si el control interno funcionaba efectivamente durante la Gran Colombia (1819-1830) en lo que se refiere a una indagación documental. Para desarrollar este estudio se ha adoptado una metodología histórico-educativa de enfoque descriptivo que se apoya en fuentes impresas que reposan en el Archivo General de la Nación, buscando reconstruir los hechos administrativos y contables acaecidos durante la existencia del proyecto republicano de la Gran Colombia.

Sobre este tipo de evaluación histórica, el planteamiento conceptual lógico que puede hacer el contador público del control interno contable, que en otros tipos de estudios se enfocaría directamente a (prevenir o) detectar errores o irregularidades importantes en los saldos de las cuentas, consiste en determinar si los procedimientos necesarios estaban establecidos y si fueron seguidos satisfactoriamente; La evaluación de cualquier deficiencia, es decir, de cualquier tipo de error o irregularidad potencial no contemplada por los procedimientos de control interno existentes, para determinar su efecto sobre la naturaleza, momento de ejecución o extensión de los procedimientos de auditoría a aplicar y las sugerencias al ente, estaría lograda al ejercer el contador público su juicio profesional en la evaluación de la información obtenida.

\section{RESULTADOS}

\section{El transcurso económico-político}

En este escrito se proponen puntos de atención acerca del impacto ejercido por la estructura administrativa del proyecto republicano de la denominada Gran Colombia sobre la fiscalidad y política de

Samuel Leónidas Pérez Grau 
Estado que no pudo ser capaz de implementar en tiempo y alcance algún plan de viabilidad para evitar el trauma de la disolución de la República.

La administración general de la República de Colombia estuvo caracterizada por la falta de control sobre el cumplimiento de compromisos de las regiones central, sur, norte y oriental, principalmente por la falta de oportuna información del Gobierno sobre los movimientos operacionales $y$ financieros de las provincias agravados por el distanciamiento y la ausencia de vías de comunicación.

La polarización ideológica entre los departamentos de la Nueva Granada, Venezuela y Ecuador estuvo instrumentalizada por la desigual responsabilidad para el sostenimiento del ejército y la distribución de la burocracia, cuyos sostenimientos no podían solventarse con los ingresos fiscales nacionales.

En línea con un enfoque financiero de la crisis fiscal suscitada, es necesario diferenciar dos vertientes para el análisis (García y García, 2000, p. I I 2):

I. Las dificultades del entorno e internas

El escenario de riesgo

El escenario de crisis

2. Las soluciones que no se implementaron

\section{Las dificultades del entorno e internas}

\section{LAS DIFICULTADES DEL ENTORNO}

Los indicios provenientes del entorno acerca de situaciones de dificultad financiera son las alertas indicadoras de que se está nucleando un problema. Estas señales pueden ayudarnos a predecir las situaciones de crisis, pero ello depende mucho de la existencia de información fiable y oportuna sobre la situación y las perspectivas del proyecto y del sector.

\section{Los indicadores de crecimiento económico}

Basándonos en las cifras publicadas por el profesor José Joaquín Pinto Bernal (2012), del Instituto de Estudios Latinoamericanos (IELAT) de la Universidad de Alcalá, es posible examinar el desempeño de los ingresos y egresos del primer período republicano, del cual podemos extractar algunos indicios:

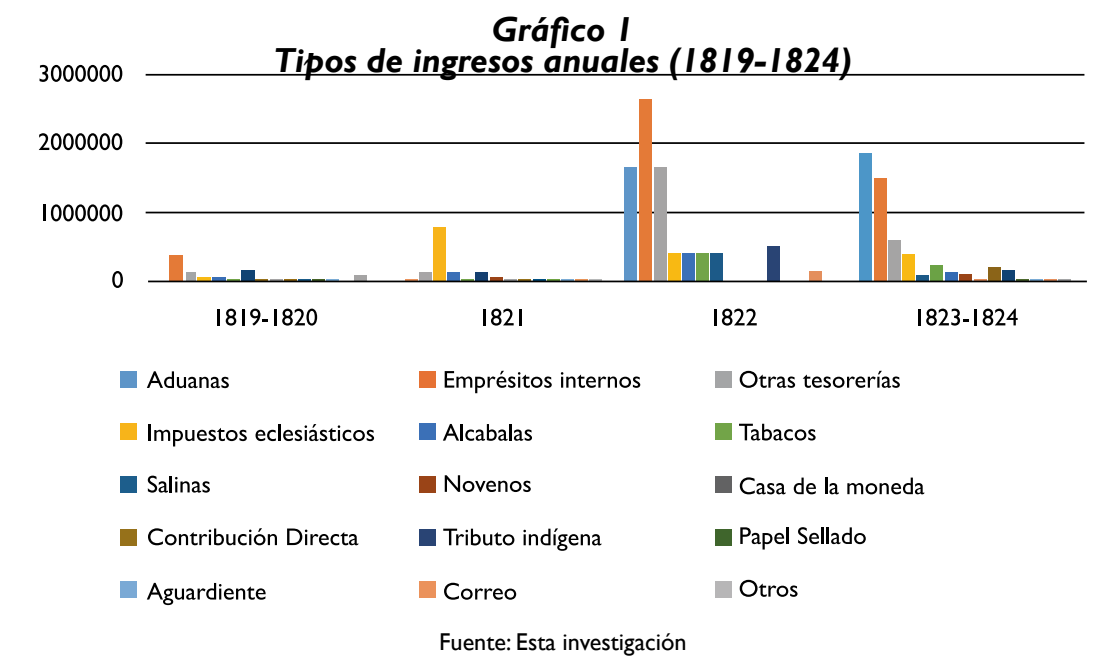

Samuel Leónidas Pérez Grau 
Los primeros efectos financieros de la intervención republicana comienzan a mostrarse a partir de los resultados de 1822 (tercer año de la transformación), precisamente en el año de los gastos militares más altos en vida del proyecto republicano. Las rentas fiscales consolidadas del período 1819-1824 ascendieron a la suma de $\$ 15.234$. I33, en cuya distribución, de entrada, puede notarse la dependencia del sostenimiento del Estado por el endeudamiento, pues los aportes obtenidos de empréstitos internos ascendían al ( $29 \%$ ), también son destacables la suma temprana alcanzada por las Aduanas (23\%), los recaudos de las Tesorerías de los otros ramos de la Administración (12\%), y los Impuestos eclesiásticos (I I \%).

Por su parte, los gastos totales del período 1819-1824 ascendieron a $\$ 58.575 .643$, repartidos entre gastos militares (81 \%), civiles (13\%) y el servicio de la deuda (6\%).

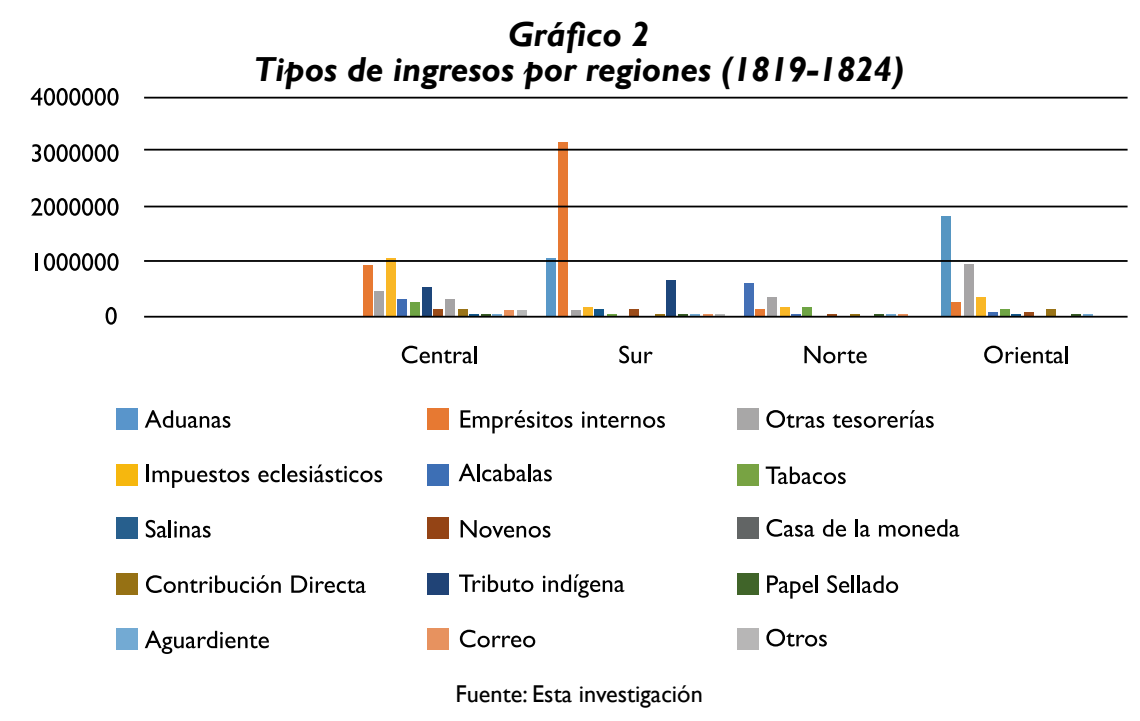

En cuanto se refiere a las regiones, la del Sur presentaba, durante el período, los ingresos más altos, aunque el $56 \%$ eran provenientes de empréstitos internos, seguidos de Aduanas (19\%) y Tributos indígenas ( $12 \%)$. Seguía la región Central nutrida por los impuestos eclesiásticos (24\%), los empréstitos internos (2I \%) y las salinas (12\%). En tercer lugar la región Oriental con el mejor recaudo de Aduanas (48\%), seguido de otras tesorerías ( $25 \%$ y los impuestos eclesiásticos $(8 \%)$. Finalmente, la región Norte con ingreso de Aduanas (4I \%), otras tesorerías (23\%), y Tabacos (12\%).

Las nuevas dinámicas económicas creadas por la Independencia tenían tres orígenes diferentes. La primera, la aparición de un ejército nacional que no solamente debía garantizar el triunfo republicano sino que tuvo que hacer frente a la resistencia irregular que sobrevivió después de 1820. Colombia tuvo que afrontar desde el comienzo de su vida independiente unos gastos elevados, derivados de la existencia de un ejército voluminoso (en 1821 estaba compuesto por 22.975 hombres, lo que equivalía aproximadamente al I \% de la población), una cifra que se incrementó a 30.466 hombres cuando se incorporaron los departamentos del sur de la República: 25.750 de infantería y 2.520 de artillería (Martínez, 2008, p. 169). La Nueva Granada tuvo también que seguir financiando los ejércitos que se enviaron al sur de América para luchar por la independencia del Ecuador y el Perú. Entre los gastos del año económico 1823-1824 (Martínez, 2008, p. 16I) están tanto los del ejército (31,7 \%), como los causados por los altos funcionarios de los poderes legislativo ( I I,7 \%), ejecutivo (7,6 \%) y judicial $(4,3 \%)$. 


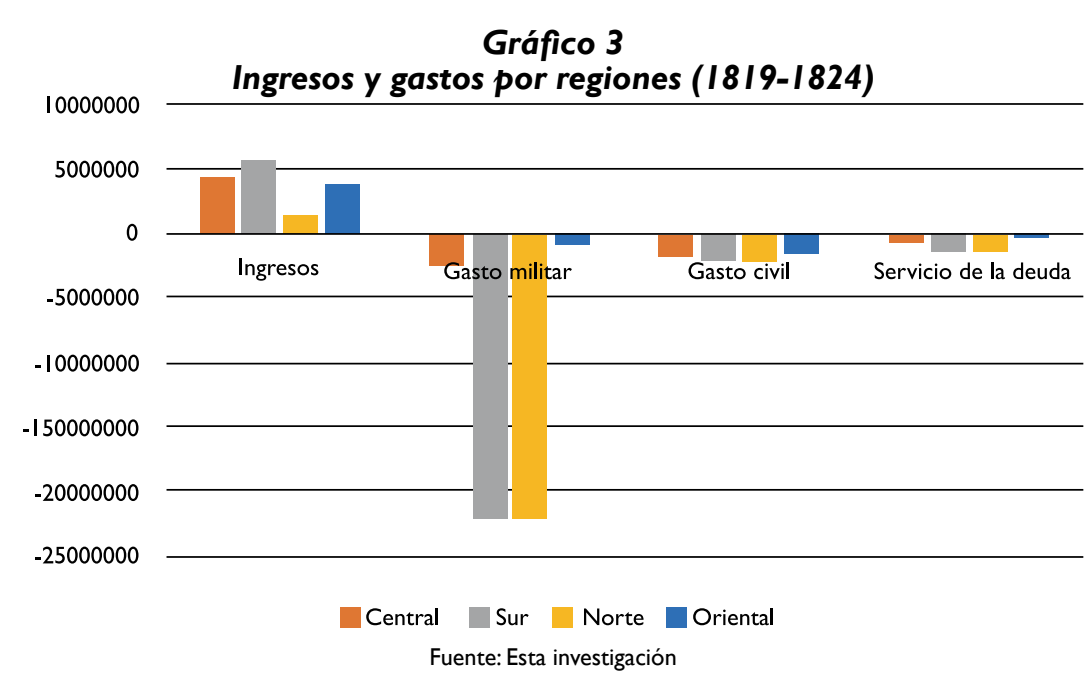

La segunda demanda provenía de la nueva burocracia estatal. A los gastos de los empleados civiles se unían los de la burocracia internacional, que comenzó a recorrer el mundo estableciendo embajadas, consulados y legaciones diplomáticas. Por último, la tercera demanda la configuraba el servicio de la deuda que adquirieron los patriotas para la guerra de liberación; que se convirtió desde entonces en una amenaza constante, ya que los intereses no pagados se convertían en nuevo capital, en un permanente círculo vicioso.

\section{Los cambios en los niveles de precio}

El proceso de expansión de exportaciones de origen agrícola y ganadero iniciado a fines de la Colonia quiso reconstruirse después de la guerra, pero los resultados de tales esfuerzos no fueron muy favorables. Durante toda la primera década republicana cayeron los precios del café y del cacao, en perjuicio de las haciendas de la capitanía de Venezuela y de Cúcuta. El algodón, principal "fruto" exportado en los primeros años del siglo, fue paulatinamente desapareciendo ante la baja dramática de los precios internacionales generada por la expansión del cultivo en Estados Unidos. La quina, que también tuvo un corto período de auge a fines de la Colonia, se había eclipsado casi totalmente a comienzos de la República (Kalmanovitz, 2006, p.217).

El algodón había sido uno de los principales productos de Venezuela y de Cartagena, pero su procesamiento de mota aún manual había generado la caída del precio hasta una tercera parte del que tenía en 1810 , por razones de calidad, habiéndose por ello decretado en el Congreso de Cúcuta su exención del pago de impuestos de exportación y de importación. Además, ninguna de las exportaciones menores tales como las de arroz, maíz y quina pudieron adquirir verdadera importancia a pesar del tratamiento preferencial que se les acordó.

Las serranías ecuatorianas, prácticamente no tenían exportaciones. Los impuestos de exportación de productos agrícolas constituyeron fundamentalmente un asunto de la incumbencia de Venezuela y Guayana. Los agricultores del interior de la Nueva Granada adelantaron una campaña para lograr la prohibición de la importación de harina de trigo norteamericana, de amplio consumo en las provincias costeras. La misma administración nombrada desde el Congreso de Cúcuta apeló a los intereses de los consumidores oponiéndose al de los productores y se señaló que una tarifa moderada produciría mayores ingresos, gracias a un mayor volumen de comercio, que una tarifa alta.

Entre las primeras reglamentaciones del comercio exterior grancolombiano estuvo la de abolir los impuestos de exportación, reemplazándolos por un sistema ad-valorem consistente en la definición 
de una tarifa del $5 \%$ aplicado sobre los valores de la factura soporte del registro de importación. Ningún tipo de tarifas preferenciales fue suficiente para detener el declinamiento de la industria del algodón, de tal modo que este producto desapareció de la lista de las exportaciones colombianas (Bushnell, 1985, p. 198).

En cambio, surgieron promisorios nuevos productos como los cueros, los tintes, y el tabaco, que comenzaría a exportarse en grande mucho después, desde la década del treinta, como resultado del interés conjunto del gobierno y los comerciantes (Kalmanovitz, 2006, p.217).

\section{Los cambios culturales y sociales}

El conflicto había sido destructivo y muchas haciendas habían quedado en ruinas. Bajo las banderas de la resistencia y la rebelión abierta, muchos esclavos huyeron hacia la frontera agrícola (Mina, 1975, pp.50-5I). Con el deterioro de la esclavitud, las haciendas del Cauca convirtieron a muchos esclavos en concertados campesinos, sometidos a relaciones de servidumbre. Esto también trajo consigo la recesión a las zonas mineras del Cauca y el Chocó y la desarticulación de las haciendas de Popayán y el valle del Cauca. El aumento del cimarronaje amenazó la seguridad de los bienes de los dueños de esclavos y redujo su capacidad para pagar las deudas contraídas en censos eclesiásticos. La liberación de los esclavos en la costa Atlántica hizo que se esfumaran los recursos para la construcción y el gasto público en Cartagena, que jalonaban el alto ritmo de la actividad económica de la región.

La primera década después de la independencia acusó un fuerte declive de la producción y las exportaciones. En cambio, el minúsculo comercio interior sufrió pocos cambios. Las vías de comunicación se reducían a caminos de herradura, la navegación a vapor por el río Magdalena se utilizaba para exportar e importar mercancías y los campesinos y artesanos no podían vender sus productos por los altos costos de transporte, lo que hacía que muy pocas personas estuvieran en capacidad de adquirirlas, disminuyendo de esta manera la posibilidad de recaudar impuestos a mercancías extranjeras.

El oro figuró como el renglón básico de exportación, a la vez que garantía para la mayoría de las importaciones de la Nueva Granada. En verdad, aparte del oro, el producto de mayor valor entre los que se enviaban a España, había poco que exportar. La producción aurífera básicamente la realizaban grandes empresas, aunque a su lado florecía la explotación de aluviones por familias de mazamorreros que a la postre ayudaron a dinamizar la economía doméstica y coadyuvaron actividades de pequeño comercio y manufactura (Kalmanovitz, 2006, p. 167).

En términos de la actividad económica, el efecto principal de las guerras de la Independencia fue el golpe propiciado a la minería esclavista del Chocó y el Pacífico, que todavía representaba a fines de la Colonia poco más del $60 \%$ de la producción de oro en el actual territorio colombiano. Aunque la producción nacional logró recuperarse parcialmente en las primeras décadas de la República, ello solo fue posible gracias a un desplazamiento de los centros de producción del metal hacia el Tolima, el Cauca medio y, particularmente, a la minería de Antioquia, que se venía ampliando al final del siglo XVIII; y siguió produciendo con base en el mazamorreo libre. Más adelante implantaría una minería empresarial mecanizada que compensó las pérdidas de otras regiones y contribuyó a una producción nacional relativamente estable. La producción nacional del 
metal debió reducirse sustancialmente, en un $40 \%$ entre $1801-1810$ y $18 \mathrm{I} \mid-1820$, de acuerdo tanto con los registros de las casas de moneda como de los estimativos de Vicente Restrepo (1952, p.7I).

Las posibilidades de un desarrollo socioeconómico estable hacían parte, tanto de una dinámica internacional en la que nos fuimos involucrando, como de la débil estructura heredada de la Colonia. Los diversos gobiernos latinoamericanos que necesitaban fondos para pagar las enormes deudas contraídas por la guerra emitieron varias series de bonos entre 1822 y 1825 a favor de bancos ingleses. Una vez concluida la contienda, fluyen grandes inversiones de penetración comercial y minera. Se crearon más de cuarenta sociedades anónimas a fin de explotar las posibilidades económicas en América Latina especialmente en el campo de la minería; tambien se abrió un gran mercado para las manufacturas inglesas que no alcanzó a ser explotado completamente, pues no existía circulante para su adquisición. Inglaterra solucionó tal problema otorgando masivos préstamos, que se utilizaron para comprar sus mercancías pero en condiciones ruinosas llevando a la práctica la desaparición de la industria nacional. Los empréstitos y las inversiones inglesas, sobre todo en ferrocarriles, se hicieron sentir y el comercio de exportación fue dirigido desde el exterior. Se dio un paso adelante en el camino del capitalismo y se retrocedió dos en el de la independencia (CGN, 1988, p.21).

Mientras la mayor parte de la artesanía rural se nutría de mano de obra esclava generadora de ingresos a sus propietarios, también existían los compañazgos o resguardos, y en menor proporción el campesinado libre al que le resultaba muy difícil separarse de la producción agropecuaria. La artesanía urbana implicaba una relación gremial que había sido reglamentada desde la época colonial en la que se perpetuaba el monopolio familiar de los oficios y limitaba rígidamente la libertad de producción y de trabajo remunerando a los maestros y aprendices mediante salarios en especie, exigiéndoles largas jornadas de trabajo, el tipo de herramientas y de capacitación.

\section{Los cambios de gobierno}

En general, la Independencia inauguró un largo proceso de inestabilidad política que resultó costoso para la sociedad. Los gastos de la Independencia fueron muy altos, siendo el mayor de ellos la pérdida del orden político que sostuvo el imperio español de ultramar durante más de tres siglos. La disminución de las rentas fiscales y la mala administración de los criollos del excedente económico ocasionó serias restricciones en materia de la provisión de bienes públicos, de la educación y de la salud, además de vías de transporte en un país de montañas que concentraba la mano de obra y la producción, en las tierras altas, lejanas de las costas.

La oportunidad para tramitar verdaderas reformas republicanas vino a presentarse en el Congreso de Cúcuta de 182I, al cual le correspondió actuar como una Comisión de Finanzas Públicas. La situación del erario público era desesperada, los estragos económicos eran evidentes, el crédito estaba agotado, la tributación y su recaudo destruido y gran parte de las energías de los constituyentes de Cúcuta estuvo dirigida a servir como un centro nervioso de recuperación financiera (Restrepo, 2010, p.62).

Sin embargo, es a partir de la Legislatura de 1824 cuando empieza una sucesión de reformas fiscales y legales que de alguna manera, trajeron modernización a la administración pública. La Ley 197 del 
3 de agosto de 1824 es la primera Ley Orgánica de administración de la República. Ella sustituye la Contaduría y la Tesorería General y crea la Dirección General de Hacienda y Rentas Nacionales, conformada por cinco frentes de trabajo: tesorería, aduana, tabaco, moneda y correo. A partir de la fecha los intendentes dejan de ser responsables de la Hacienda pública la cual empieza a ser administrada por las Juntas de Hacienda, integradas por el intendente, el contador y el tesorero departamentales para que en forma especial aprobaran gastos extraordinarios que por su urgencia no dieran tiempo a ser consultados con el poder ejecutivo central. Las contadurías departamentales serían las encargadas de examinar, glosar y fenecer las cuentas de las tesorerías y administración e informar los resultados de cada juicio a la Dirección General. En cada departamento se estableció una tesorería departamental y en cada cantón una tesorería foránea o una colecturía de rentas dependientes de las tesorerías departamentales. Los gobernadores hacían de subdelegados de la Dirección Nacional. Para el establecimiento de las aduanas, el Vicepresidente habilitó 15 puertos en el Atlántico y cuatro en el Pacífico.

\section{LAS DIFICULTADES INTERNAS}

Los indicios internos coadyuvantes de situaciones de dificultad financiera son los síntomas de los que tratamos de identificar las causas que los producen para poderles prevenir.

\section{Pérdida de la productividad}

El auge minero en Colombia no había comprometido solamente a los grandes empresarios nacionales y extranjeros, sino que en torno a la expansión de la minería de aluvión se arremolinaron centenares de familias que trabajaban cascajeros y dependían de ingresos muy pequeños. Estos mineros, denominados mazamorreros a fines de la Colonia, crecieron con el siglo XVIII; con la libertad y manumisión de esclavos su número se acrecentó. Las dificultades de encontrar oportunidades diferentes hacían que el sector creciera junto a las grandes minas. Su producción fue muy importante en Antioquia, Tolima y Cauca, al igual que en el Chocó, pero es muy poco lo que aún conocemos sobre su actividad económica y social. Por un informe de 1832 sabemos que, al menos en el Cauca, no eran propietarios de suelos y su presencia era vista como factor de destrucción ecológica, constituyéndose de hecho en un problema social para la zona y para aquellos grandes señores cuyas minas limitaban con las de estos modestos trabajadores (Ocampo, 1984, p.52).

En las dos primeras regiones, los principales esfuerzos estuvieron a cargo de empresas extranjeras, que vieron en la minería de oro su principal oportunidad de inversión en la naciente república. Pese a los capitales invertidos y a las innovaciones técnicas, los esfuerzos iniciales de estas compañías no fueron exitosas. En la región de Mariquita se repitieron los fracasos de Juan José D'Elhuyar en las últimas décadas del siglo XVIII. En efecto, en 1824 el gobierno de Colombia arrendó las minas de Santa Ana y la Manta en esta región del país a la casa inglesa Herring, Graham y Powels, por cuenta de la Asociación Colombiana de Minas. Hasta 1836, la firma había invertido allí más de $\$ 1.100 .000$, sin éxito.

\section{Baja cultura empresarial}

Propiamente, el grueso de los ingresos globales de la sociedad granadina provenía de la actividad artesanal y agrícola explotada con un sentido de consumo. Tal vez la actividad sobre las que recayeron las mayores esperanzas de progreso fue el comercio, a partir de la creencia de que era el responsable de la creación de la riqueza. 
Las empresas que surgieron durante la primera mitad del siglo XIX respondieron a unas necesidades mercantiles diversas en materia de negocios. La dinámica contextual del empresariado estaba volcada hacia afuera, debido a la entrada de mercancías extranjeras de mejor calidad y más baratas que las elaboradas por los artesanos cundiboyacenses de los mercados locales.

Muchas veces, a partir de los ahorros tanto de las familias dedicadas a la pequeña minería como a la producción agraria y la artesanía rural, surgieron iniciativas para atender una creciente demanda de mercancías y utensilios que se convirtieron en actividades diversificadas de comercio y manufactura. Dadas las condiciones contextuales y la tardía inserción de los propietarios en el mercado internacional, surgieron muchos negocios diversificados. El núcleo inicial de este tipo de actividad lo configuraban las llamadas "Casa Comercial", de apariencia homogénea, que pudo resolver la complejidad de las operaciones y del control mediante la figura jurídica de la asociación, en la que cada una de las porciones de la inversión patrimonial quedaba protocolizada mediante un contrato mercantil por escritura pública (Ariza, 200I, p. 138).

En la Nueva Granada, el inversor especulador actuaba con una racionalidad dual: por un lado, la patrimonialista o señorial, heredada de la Colonia, y por el otro lado, la financiera mercantil fundamentada en sus relaciones comerciales con Francia, Inglaterra y los Estados Unidos, aunque no siempre en adecuadas proporciones y resultados eficaces. La gestión productiva quedó en manos de los socios industriales, administradores, mayordomos, directores, técnicos, mientras los propietarios concentraban su función en el manejo del recurso financiero. La información contable como expresión sociocultural reflejaba la racionalidad dominante en la esfera económica mercantil y era a la vez una guía para el afianzamiento de los demás comerciantes, mineros e inversores financieros acerca de su comportamiento como empresarios organizados.

\section{Los primeros síntomas de dificultad fiscal}

Mientras que las proyecciones del Secretario de Hacienda acerca del recaudo en 1822 por contribuciones directas ascendían a $\$ 2.868 .000$, lo realmente recaudado arrojaba apenas $\$ 24.666$. El Vicepresidente pidió entonces a la Cámara de Representantes la aprobación de una ley que pusiera fin a la impunidad de los contribuyentes y que castigara a los funcionarios que actuaran con parsimonia en la tarea fiscal. La legislatura de 1823 aprobó entonces una ley que suspendió este cobro, sustituyéndolo por un tributo sobre todas las propiedades muebles e inmuebles y los capitales, que sería recaudado en un término de 30 días. Serían cobrados un peso para los propietarios de bienes avaluados entre 100 y 200 pesos, dos pesos para quienes tuviesen entre 200 y 500 pesos, cinco pesos para quienes tuviesen de 500 a 1.000 pesos y así sucesivamente. A los empleados civiles y militares les sería cobrado un tributo del 2 al $5 \%$ de sus salarios y a los profesionales abogados y médicos 8 pesos (Martínez, 2008, p. 158).

Obviamente, la contribución directa desplazaba la base tributaria hacia quienes tenían mayor capacidad de pago. Por eso no estaban tan alejados de la verdad los funcionarios que atribuían la oposición de la contribución directa a los ricos terratenientes, el clero y otros grupos similares que habían sido afectados muy poco por la alcabala pero que los obligaba ahora a pagar un porcentaje fijo de su capital o de sus ganancias al Tesoro Nacional. 
La tarea de los jueces políticos era ardua: integrar en cada parroquia juntas calificadoras y nombrar colectores, formar listas de contribuyentes y después convocar a los ciudadanos para que manifestaran en Dios y en conciencia cuánto era el valor de los capitales de cada uno y cuál la ganancia que anualmente les producían. Luego había que fijar en lugares públicos las listas de contribuyentes de cada parroquia con su respectiva contribución (Martínez, 2008, p. 156).

Los sistemas de recaudación eran engorrosos y muy pocas personas querían emplearse como recaudadores. El Gobierno no dejaba de presionar a estos funcionarios para que mantuvieran un control verdaderamente efectivo en las provincias alejadas, por temor a que encontraran un medio de abandonarlo. El recaudo podía omitirse en regiones enteras comoVenezuela donde los empleados de rentas llegaron a tener hasta dos años de atraso en la preparación y aprobación de los formularios para los balances; en Guayaquil y también en algunos puertos de la Nueva Granada se cobraban impuestos cuya naturaleza desconocía la autoridad central. En Bogotá, donde siempre se cobró con atraso, nunca se pudo recaudar durante un semestre completo (Bushnell, 1985, p.l I0).

Además, era un hecho la amplia tradición de tolerancia de las autoridades, lo que podía explicar la cada vez más generalizada evasión fiscal. Influía el hecho de que las necesidades militares dejaban pocas veces fondos suficientes para pagar la nómina de los servidores civiles. A veces un decreto del Ejecutivo o del Legislativo ordenaba a los empleados civiles y los soldados recibir una tercera parte 0 la mitad de sus sueldos. Cuando no se pagaba a tiempo, en forma total, la parte restante se convertía automáticamente en una deuda interna nacional que debía pagarse en alguna fecha futura.

\section{Incremento de los gastos financieros}

El medio principal que encontró la naciente república para enfrentar la insolvencia de sus primeros días fue la rápida expansión del endeudamiento interno, originado parcialmente en la compra rutinaria de provisiones para la guerra, a crédito. Con el correr del tiempo, el mayor renglón de la deuda interna llegó a constituirlo el pago aplazado a los empleados civiles y militares, lo que estuvo aún más incrementado, por la inclusión de las acreencias de la Patria Boba y del gobierno provisional establecido en los llanos durante la pacificación española asignadas a los veteranos de las campañas venezolanas de 1816-1819, patrocinadas por la legislación de bonificaciones del Congreso de Angostura, el reconocimiento de la deuda de los españoles a los habitantes del Istmo, como condición para el ingreso de Panamá a la nueva República. La deuda que había dejado el régimen español entre la comunidad comercial de Guayaquil, el recrudecimiento de la guerra en 1819 y la deuda colonial en la forma de censos eclesiásticos, todas fueron reconocidas bajo el Congreso de Cúcuta.

Con autorización del Congreso de Cúcuta, la administración había intentado conseguir previamente préstamos de $\$ 80.000$ en 1822 y de $\$ 300.000$ un poco después en aquel mismo año, para recuperar la pérdida de Maracaibo. Ninguno produjo más de la mitad de lo que se buscaba. La más grande autorización la dio el Congreso de 1823 que decretó obtener un empréstito general interno de $\$ 500.000$, sobre el que a pesar de la oferta de Santander de negociarlo al $10 \%$ de descuento y tasa de interés del $6 \%$ y la promesa de pagarlo utilizando parte del producto de un esperado crédito inglés, los comerciantes de Bogotá tan solo prestaron $\$ 3.000$, los de Cartagena $\$ 4.000$ y los de Panamá $\$ 30.000$. Los de la firma Arrubla y Montoya aceptaron adelantar $\$ 50.000$ (Bushnell, 1985, pp. 124-125). 
Una razón para que los resultados fueran tan desalentadores era que los inversionistas habían sido explotados continuamente por una serie interminable de empréstitos o pedidos de provisiones, generalmente involuntarios, impuestos por los empleados civiles o militares. Dado que el Gobierno ya "no tenía por el momento medios suficientes para proveer a los diferentes cuerpos de operaciones", decretó en 1822 que un oficial con mando podía tomar lo que necesitara, expidiendo un recibo formal que sería reconocido como una obligación legal del Gobierno. El problema fue entonces, que los oficiales dejaban a veces de expedir los recibos por lo que debió entonces aceptarse la prueba testimonial, en vez de la prueba documental. Este hecho vino finalmente a constituirse en una de las fuentes más fértiles para el fraude en toda Colombia.

El nivel más alto del endeudamiento interno se alcanzó probablemente en 1824 y el estimativo más conservador de la deuda parece ser la cifra de $\$ 10.000 .000$ citada por Joaquín Mosquera en el curso de un debate senatorial sobre la crisis fiscal en 1825. Por supuesto, la deuda nacional estaba garantizada con la riqueza e ingresos del Estado e instrumentalizada mediante vales convertibles en pagos de impuestos, derechos de aduana o tierras baldías, lo que por su parte, dio lugar al surgimiento de la ola especulativa de los diferentes tipos de certificados jamás conocida en Colombia.

\section{Venta del inmovilizado necesario}

Otro de los grandes efectos de la Independencia y de la República, organizada por los criollos, fue una mayor concentración de la propiedad de la tierra con la reducción de las tierras de resguardo indígena, la liquidación de la propiedad comunitaria, incluidos los ejidos, y la titulación de baldíos a favor de militares, empresarios y agiotistas que poseían deuda pública respaldada por las tierras del Estado. Los soldados recibieron vales para ser cambiados por tierras, pero los caudillos y altos oficiales se los compraban por una fracción de su valor. "Una nueva élite de terratenientes, recompensada con propiedades secuestradas o tierras de la nación, se unió a los propietarios de la colonia y en algunos casos los remplazó. Los soldados que no habían recibido lo que se les debía se quejaron con amargura del funcionamiento de las comisiones de tierras" (Lynch, 2006, p.212).

\section{Disminución de la calidad del beneficio}

La primera de todas las reformas tributarias fue dirigida contra los derechos aduaneros internos y el impuesto sobre las ventas conocido como sisa o de la porción de carnes muertas, los cuales no generaban rentas muy importantes (Bushnell, 1985, p. 102).

Se unificaron todos los antiguos impuestos cobrados en los puertos en uno solo, llamado derecho de importación; pero se mantuvo el derecho de toneladas cobrado a los buques; se declaró que las salinas serían administradas directamente por la República o por concesionarios, incluyendo aquellas que habían sido explotadas en forma privada bajo el régimen español; se conservó el cobro del derecho del quinto de minería para todas las extracciones de oro, plata y cobre, así como los derechos de amonedación en las casas de moneda existentes en Bogotá y Popayán.

La alcabala fue suprimida por la Ley del 3 de octubre de 182 I sobre todo tipo de transacciones de productos alimenticios e industriales que se conducen de pueblo a pueblo, cuya tasa normal había sido del $5 \%$ ad valorem que recaía sobre tipos de frutos y de provincias y desde entonces solo se cobró con una tasa reducida del $2,5 \%$ en las 
ventas de propiedades raíces y de mercancías importadas y algunos peajes (Restrepo, 2010, p.7I).

También se resolvió la abolición del tributo de indios y la creación por primera vez en nuestra historia impositiva de un impuesto directo a las rentas y las riquezas. El tributo indígena, era en el fondo un impuesto per cápita directo y si bien era considerado discriminatorio, dispensaba a la población indígena de todo otro tributo directo o indirecto (Restrepo, 2010, p.74). La Ley del 4 de octubre suprime la renta estancada de aguardientes, que ya no existía en Venezuela, y se declaró libre su destilación y tráfico (Restrepo, 2010, p.76).

Se modificó la estructura de los diezmos, o sea, la décima parte que pagaba el cultivador en tiempos de cosecha por los frutos de la tierra. En lo sucesivo, la República se quedaría con una novena parte de toda la masa de los diezmos y con dos novenos de las vacantes eclesiásticas.

El siguiente cuadro muestra la manera en que los obispados distribuían la producción agrícola:

\begin{tabular}{l|l|c|c|}
\multicolumn{4}{c}{$\begin{array}{c}\text { Cuadro I } \\
\text { Distribución de la producción agrícola } \\
\text { por parte de los obispados }\end{array}$} \\
\hline \multicolumn{1}{c|}{ Beneficiario } & \multicolumn{1}{c}{ Denominación } & Fracción & $\%$ equivalente \\
\hline El prelado & Cuarta episcopal & $1 / 4$ & $25,0 \%$ \\
\hline Diácono y cabildo & Cuarta de mesa capitular + 4/9 & $1 / 4+(4 / 9)(1 / 2)$ & $46,9 \%$ \\
\hline La corona (el Gobierno) & $2 / 9$ de su majestad & $(2 / 9)(I / 2)$ & $11,4 \%$ \\
\hline Hospital (sin prelado) & Uno y medio noveno & $(I, 5 / 9)(1 / 2)$ & $8,3 \%$ \\
\hline Fábrica de iglesias & Uno y medio noveno & $(1,5 / 9)(1 / 2)$ & $8,3 \%$ \\
& Total & $2 / 2$ & $99,9 \%$ \\
\hline \multicolumn{4}{|c|}{ Fuente: Purroy, 1986, p. 161} \\
\hline
\end{tabular}

Se reorganizó el ramo de correos y se incrementó la renta del papel sellado. En cambio, no fue tocado el monopolio o estanco del tabaco que al estallar la revolución era ya la principal renta fiscal, aunque se le tenía muy poca simpatía por el hecho de requerir inversiones importantes para mantenerlo rentable y para comprar las cosechas con el fin de evitar fraudes. El estanco de los naipes fue unificado con el del tabaco hasta 1826, año en que fue liberada su comercialización (Martínez, 2008, p. 155).

Además, fueron suprimidos algunos gravámenes particularmente opresivos u odiosos, tales como la venta de ciertos cargos públicos, el derecho que pagaban los mazamorreros que lavaban oro en pequeña escala, la instrucción básica que estaban obligados los indígenas, las deducciones denominadas: mesada eclesiástica, las medias anatas, la anualidad de las rentas o emolumentos de ciertos cargos civiles o eclesiásticos.

Para compensar la pérdida en ingresos fiscales, se impusieron varios impuestos nuevos a la manufactura y venta privada del aguardiente y se reglamentó la forma de recaudarlos en unos 24 artículos cuya tasa variaba entre el $15 \%$ y el $35 \%$ dependiendo de la naturaleza del artículo a gravar (Bushnell, 1985, p. 105). Pero a pesar de las intenciones, los nuevos impuestos rindieron solamente una fracción del ingreso anterior.

\section{EL ESCENARIO DE RIESGO}

El conjunto de indicios externos e internos configuran un escenario de riesgo que obliga a tomar medidas oportunas. Por lo general, las primeras medidas a tomar bajo escenario de riesgo serán de carácter financiero las cuales tienden, en primer lugar, a corregir las

Samuel Leónidas Pérez Grau 
deficiencias coyunturales conducentes a situaciones de solvencia y cuando estas medidas no fueren suficientes, se hará entonces necesario entrar en esferas estructurales para acogerse a otras alternativas posibles.

Una de las primeras acciones gubernamentales del Congreso de la República intentando controlar la situación de riesgo fiscal que se manifestaba en ascenso, consistió en expedir autorización al vicepresidente Santander para conseguir en Europa un empréstito hasta por la suma de treinta millones de pesos. Debido a obligaciones anteriores que habían sido incumplidas, la suma efectivamente recibida por Colombia corresponde aproximadamente a la mitad de lo que decía el decreto del 24 de mayo de 1824. La otra mitad, fue a manos de corredores e inversionistas ingleses, con excepción de la comisión pagada a Hurtado que comprendía lo prestado de Zea más el nuevo préstamo. Entre Arrubla y Montoya recibieron el I \% del nuevo préstamo. Por otra parte, la crisis financiera europea de 1825-1826 obligó a la casa Goldschmidt a declararse en quiebra el 15 de mayo de 1826, arrastrando consigo una parte considerable del empréstito ( 350.000 sobre las que ya habían sido giradas órdenes de pago por 49.53I libras esterlinas) que Hurtado había dejado en depósito en sus manos en vez de guardarlas en un banco (Barriga, 2010, p.65I).

Otra acción muy importante del Gobierno fue la promulgación de la Ley del II de abril de 1825 con la cual define las rentas municipales y les encarga el pago de los gastos de policía urbana y rural; otorga licencias para el degüello del ganado, la venta de víveres y bebidas expendidas en almacenes, pulperías y bodegas, el uso de las pesas y medidas, los juegos y galleras, el uso de aguas de acueductos, molinos, puentes y las tierras comunales. El producido debería aplicarse al pago de réditos a los censos, la nómina de empleados municipales, la construcción de cárceles, el mantenimiento de casas municipales, las fiestas nacionales y religiosas, los maestros de escuelas, salubridad y ornato. Los varones mayores de $2 \mathrm{I}$ años deberían prestar el servicio de cuatro días anuales por persona para la composición de caminos vecinales o responder por los jornales sustitutivos.

Seguidamente, la Ley del 4 de mayo de 1825 intentó ayudar al Ejecutivo en la tarea de salvar la contribución directa restituyéndola, mediante la ampliación de la exención para los propietarios cuyos bienes no sumaran más de $\$ 200$ y además, el Ejecutivo expidió el reglamento esperado: los recaudadores colectores de impuesto elaborarian un catastro detallado de todas las casas y predios rústicos existentes en todas las parroquias, con su valor y lo que producían por arrendamientos, sobre lo cual se gravaría el impuesto directo. También deberían hacer un listado de todos los contribuyentes de las parroquias distinguiendo sus profesiones en las siguientes categorías: comerciantes y mercaderes, pulperos y bodegueros, abogados, escribanos y notarios, agentes, procuradores y solicitadores de causas, tasadores de costas, médicos, cirujanos, sangradores y boticarios, maestros de oficios, fondistas y bodegoneros. Con toda esta información detallada, podría procederse a la imposición del gravamen directo, según las tasas de la Ley del 28 de septiembre de 182I (Martínez, 2008, p. 162). Así, los comerciantes quedarían pagando $\$ 1.300$ anuales, los vendedores de bienes de lujo en el interior $\$ 500$, los intermediarios $\$ 275$, los dueños de bodegas $\$ 650$, los pulperos $\$ 126$, los empleados del tesoro $3 \%$ de su sueldo, los abogados $\$ 80$ y los escribanos $\$ 90$ (Pinto, 2013, p.59).

A la razón, Bolívar desde La Paz, el 17 de septiembre de 1825, escribe 
al vicepresidente Santander: "Yo he decretado aquí que todas las minas perdidas y abandonadas pertenecen de hecho al gobierno para pagar la deuda nacional. Desde luego en Colombia se podía hacer lo mismo y venderlas todas a una compañía inglesa, a cuenta de pagos de intereses por la deuda nacional. Yo creo que bien podemos sacar algunos millones por este arbitrio; pues el momento es muy favorable para negocios de minas" (Lecuna, 1947,T.II, p.218).

Un mes más tarde, enterado de que el conjunto de acreencias que pesaban sobre Perú era de tal cuantía, en extensa postdata de carta dirigida el 17 de octubre de 1825 desde Potosí, Bolívar comunica a don José Larrea y Loredo, ministro de Hacienda de la junta de gobierno peruana, un plan desesperado:

Como siempre estoy pensando en el Perú por sus deudas, me ha parecido bien indicarle al gobierno que amortice la deuda nacional ofreciendo sus minas y todas sus tierras baldías que son inmensas añadiendo además todas sus propiedades raíces, todos los derechos de invenciones y exclusivas y todos aquellos arbitrios útiles que el gobierno pueda conceder parcialmente a beneficiados que pocos nos darían. En fin, mi idea es que el gobierno dé todo cuanto le pertenece por amortizar su deuda, a una o muchas compañías inglesas o a los mismos tenedores de los vales del gobierno; quiero decir que estos señores se encarguen de la negociación de aniquilar la deuda por el valor de las propiedades y de las gracias que antes he mencionado. Para lograr estas vastas empresas se debe formar un magnífico proyecto del plan, tomar una relación exacta de las propiedades del Estado inclusive las tierras baldías, que deben ser infinitas; después, ofrecer las gracias que el gobierno pueda conceder; $y$ últimamente, decir que el gobierno pesará las proposiciones que se le hagan $y$, en vista de ellas, formará una contrata formal en la cual se hallarán especificadas las condiciones del caso. (Lecuna, T.Il, pp.242-246)
En 1825 la casa Goldschmidt tomó en arrendamiento varias minas de oro y plata en Marmato y Supía. El mismo año llegó al Cauca Medio Juan B. Boussingault, quien compró, por cuenta de la Asociación Colombiana de Minas, varias minas en Marmato, Supía y Quiebralomo. La innovación más importante de Boussingault fue la instalación de un molino simple de pisones, fabricado casi en su totalidad con madera, que sustituyó los molinos primitivos hasta entonces para triturar las rocas. Además, introdujo definitivamente los molinos de arrastre para amalgamar los metales preciosos con mercurio, un proceso ampliamente conocido en Perú y México desde siglos anteriores, que permitió reducir las pérdidas en el procesamiento de un 80 a un $25 \%$. Pese a tales avances, los resultados económicos de esta compañía tampoco fueron satisfactorios. A diferencia del patrón típico en el Tolima y en el Cauca Medio, los esfuerzos más importantes de organización de una nueva minería empresarial en Antioquia corrieron por cuenta de capitalistas de la región que contaron, sin embargo, con la asesoría de algunos técnicos extranjeros. En efecto, en 1824 la mina del Zancudo fue adquirida por José María Restrepo. Hacia 1826, Francisco Montoya y otros capitalistas formaron la Sociedad de Minas de Antioquia para explotar tres minas de veta en Santa Rosa (Tovar, 1987, p. 105).

De todos modos, Bolívar aplica en el Perú, el detestable recurso y, el 18 de octubre de 1825 , comunica desde Potosí al vicepresidente Francisco de Paula Santander:

Ud. me dice que ha arrendado las minas y he visto por los papeles públicos que se han dado tierras para colonias, y vendido parcialmente todos los beneficios de que podía disponer el Estado. Yo he vendido aquí las minas por dos millones y medio de pesos y aun 
creo sacar mucho más de otros arbitrios, $y$ he indicado al gobierno del Perú que venda en Inglaterra todas sus minas, todas sus tierras y propiedades y todos los demás arbitrios del gobierno, por su deuda nacional, que no baja de veinte millones. (Lecuna, 1947, T.II, Pp.252-253)

Teniendo en cuenta la situación de postración del proyecto de la posguerra y la instauración de un orden tributario modernizador de las instituciones y de libertad social, podemos considerar que las primeras acciones de los funcionarios encargados de desarrollar el proyecto republicano no estuvieron mal enfocadas, sin embargo se hace necesario seguir profundizando en el tema para intentar descubrir los factores administrativos y estructurales que a la postre impidieron implementar apropiadamente estas reformas fiscales que prometían satisfacer plenamente las demandas de desarrollo que planteaba el nuevo país.

En términos administrativos y estructurales, el período 1824-1827 es trascendente para el proyecto republicano, pues en él se promulgan tres leyes orgánicas que otorgan una relativa descentralización administrativa y proporcionan un aceptable incremento de los ingresos aduaneros tras la habilitación de 15 puertos: la primera la Ley del 3 de agosto de 1824 mediante la cual el Congreso suprimió la Contaduría y la Tesorería General sustituyéndolas por la Dirección General de Hacienda y Rentas Nacionales; la segunda, la Ley del II de mayo de 1825 por la que se separan los poderes Ejecutivo y Judicial, ordenando la existencia de una Alta Corte en la capital y la creación de Cortes Superiores de Justicia en cada uno de los departamentos, y la tercera, la Ley del 18 de abril de 1826 con la que se define la Fuerza Armada Nacional y se establece la atribución del
Congreso para fijar anualmente el tamaño del ejército permanente.

Lo destacable del período en materia de ingresos es el crecimiento de los ingresos a una tasa anual del $14,7 \%$ a partir de una masa monetaria de $\$ 21.943 .918$ y, el desplazamiento al primer lugar por los ingresos de Aduana (37 \%) pasando los Empréstitos internos (25\%) a un segundo lugar. El tributo de la contribución directa tuvo un crecimiento del $15 \%$, pero seguía siendo insignificante en el total del recaudo ( $(I, 8 \%)$. Durante el período empiezan a bajar los gastos militares, pero comienza a subir el servicio de la deuda que ahora incluye el endeudamiento externo. Los gastos totales del período 1824- 1827 ascendieron a $\$ 22.093 .28$ I, repartidos entre gastos Militares (46\%), gastos Civiles (35\%) y el Servicio de la Deuda (19\%).

La promulgación de las mencionadas leyes orgánicas, aunadas a la llegada de los recursos provenientes del endeudamiento externo, trajo nuevas dinámicas económicas.

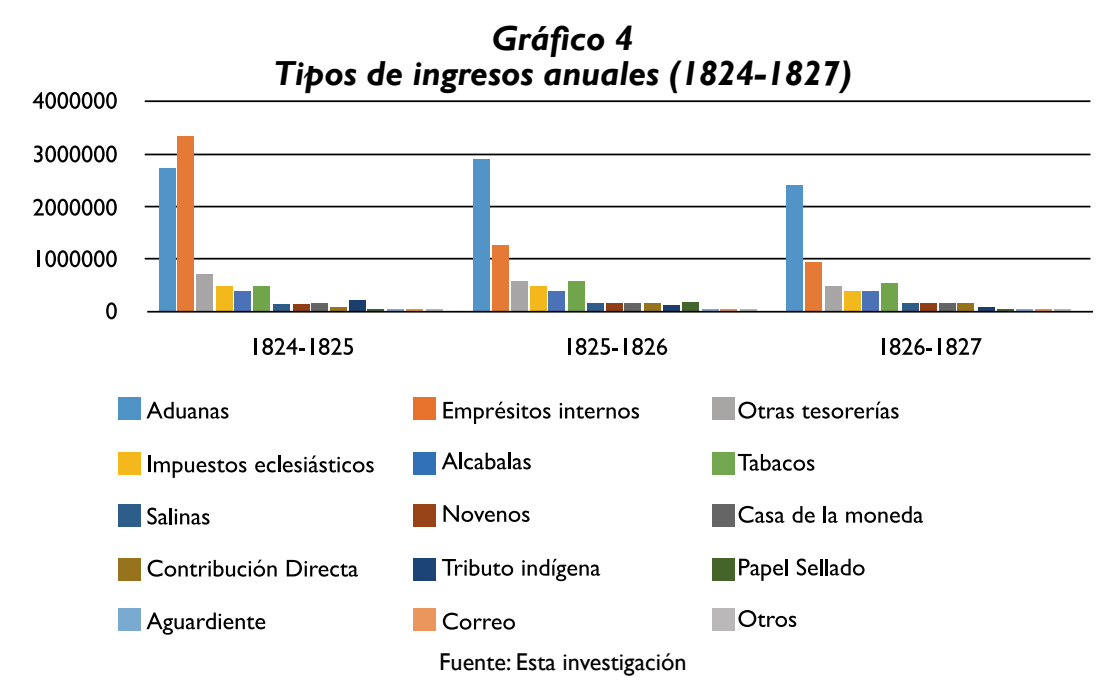

Samuel Leónidas Pérez Grau 


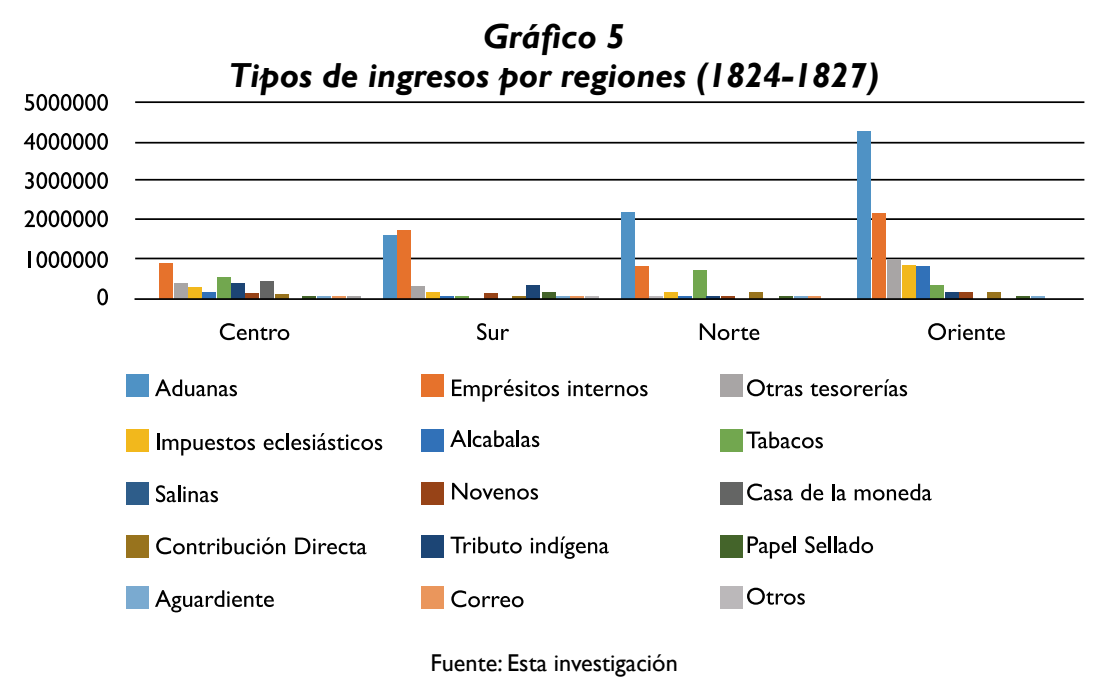

Por una parte, la dinamización de las aduanas y por la otra, la aplicación de los fondos provenientes del endeudamiento externo al pago de la deuda interna, hizo decrecer el peso de la dependencia por los empréstitos internos, más que todo por la supresión, por lo menos momentáneamente, de la recurrencia a los préstamos forzosos por parte de las autoridades.

Examinando lo mismo sobre las regiones, se observa que durante el período 1824-1827, la región Oriental presentaba los ingresos más altos siendo el $43 \%$ de estos provenientes de Aduanas, seguido de Empréstitos internos (22\%) y Otras tesorerías (10\%). La región Sur seguía teniendo los Empréstitos internos $(37 \%)$ como su mejor fuente, seguida de Aduanas (35\%) y los Tributos indígenas (8\%). En tercer lugar la región Norte con Aduanas (53\%), Impuestos eclesiásticos (27\%), Empréstitos internos (19\%) y Tabaco (17\%). Finalmente, la región Central con Empréstitos internos (27\%), Tabacos (16\%), Casa de Moneda (13\%) y Otras tesorerías (II \%) igual que Salinas $(11 \%)$
Los gastos militares disminuyeron con motivo de la finalización de la Campaña del Sur pero se mantenían aún magnificados en las regiones Central y Oriental en prevención de situaciones de conflicto ante los movimientos políticos regionales y desórdenes ciudadanos. Los gastos civiles se habían ido estabilizando y se mostraban crecientes en las regiones Oriental y Sur por la creación de los nuevos gobiernos provinciales de los territorios recién liberados. Lo del Norte se explicaba por su sostenimiento de la administración de Panamá.

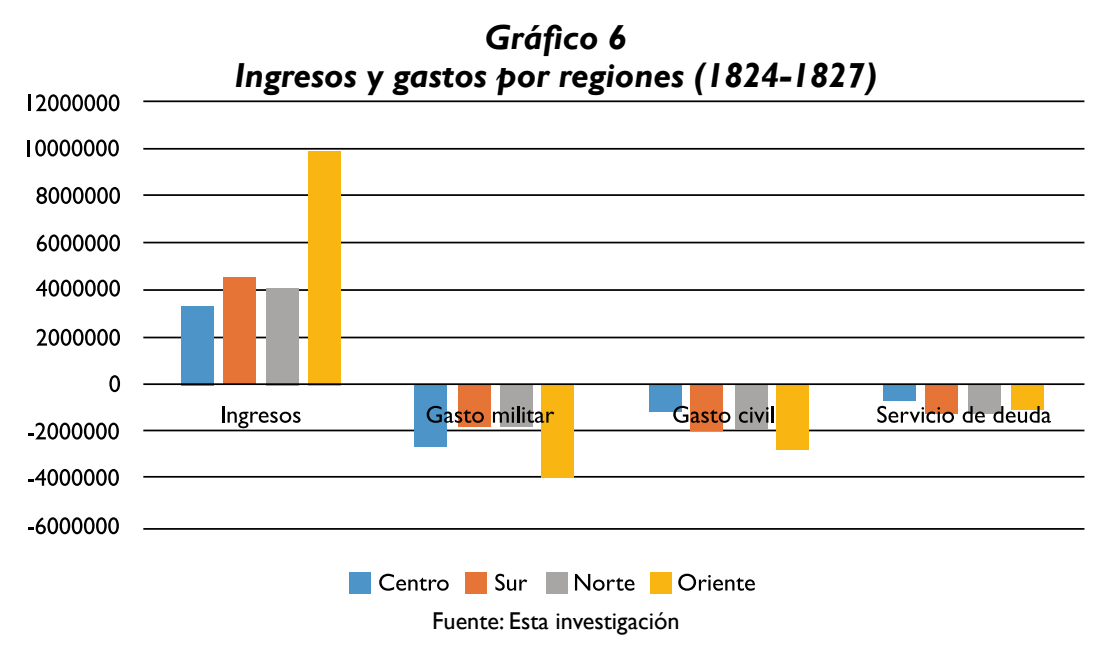

\section{El empréstito de 1824}

No puede negarse que una de las razones para acelerar la creación de la Gran Colombia sería la posibilidad de obtener créditos. El problema de la deuda, su continuo crecimiento, las infortunadas negociaciones que la incrementan y los intentos de cancelarla es tema que atormenta en forma casi permanente al Libertador.

En comunicación que Bolívar dirige el 20 de diciembre de 1819 desde Angostura a Santander, vicepresidente de Cundinamarca, dice:

Samuel Leónidas Pérez Grau 
Nuestros agentes en Londres, los señores Peñalver y Vergara, participan al gobierno que las disposiciones del pueblo británico nos son muy favorables, $y$ aun las del gobierno. No desesperan de conseguir el empréstito de los 3.000 .000 de duros que motivó su misión, a pesar de haber encontrado en la cárcel arrestado por una deuda de 150.000 pesos al señor José María del Real, agente de la Nueva Granada en aquella corte, quien obtuvo su libertad bajo la fianza y garantía de dichos señores. Ellos propenden, según la disposición de la Gran Bretaña, a la unión de las dos repúblicas, y creen que nuestro crédito y reputación se aumentará considerablemente con este acto... Esta es también una de las poderosas razones que ha considerado el congreso para la reunión de las dos naciones, los dobles medios y de consiguiente el doble crédito que va a resultarnos. Casi no puede dudarse de que conseguiremos el empréstito, a la vista de la importancia y de las seguridades que presta la República de Colombia. (Lecuna, 1947, T.I, p.407)

Así, después de que en 1819 Bolívar ejecuta el audaz paso de los Andes y consagra la libertad de la Nueva Granada en la batalla de Boyacá; desde Bogotá, el 8 de marzo de 1820, dirige proclama a los colombianos en la cual exhorta a la unión de los pueblos hermanos, y en esa misma fecha envía comunicación al vicepresidente Juan Germán Roscio en la cual le ordena entrar en negociaciones con los acreedores ingleses para satisfacerlos con minas:

V.E. tratará de solicitar con las casas de Londres, a quienes la República es acreedora por los auxilios que han suministrado, que tomen estas minas, llamadas Santa Ana de Laxas, por las deudas que les reconocemos, con las condiciones de no tener que pagar derecho alguno de los comunes al ramo de minas en los primeros diez años de su laboreo, o de recibirlas el Estado en caso de no querer seguir los contratistas, abonándoles los gastos que hubieren impedido en ponerlas en estado de utilidad. Si no se conviniere, se solicitará que dichas casas nombren una comisión que asociada a un factor de la parte del gobierno, trabaje la mina de mancomún; y sus productos, después de reintegrados los costos, servirán exclusivamente para pagarles la deuda nacional. (Pérez Vila, 1959,T.XII, p. 175)

En menos de 90 días de transcurridos después de la insistencia del Secretario de Hacienda en su informe de mejoras de 1823 ante el Congreso, muy prontamente fue expedida una autorización especial al vicepresidente Santander (según Decretos de I y 31 de julio de 1823 y modificada según Decreto de 24 de mayo de 1824). En este último decreto, el vicepresidente Santander reservó la diligencia del arreglo de los endeudamientos y moratorias del anterior empréstito de 1822 a Manuel José Hurtado, a la sazón primer ministro colombiano acreditado en Londres y comisionó a sus dos cercanos amigos Manuel Antonio Arrubla y Francisco Montoya para tramitar un nuevo empréstito. Hurtado logró la aceptación de Herring, Graham y Powels de todas las transacciones hechas por Francisco Antonio Zea, exprimer Vicepresidente de Colombia, desde su llegada a Inglaterra y la promesa de entregar las sumas que todavía debían del préstamo, todo ello hasta comprometer la tercera parte del nuevo empréstito autorizado. Por su parte, Arrubla y Montoya pudieron obtener un nuevo préstamo por los restantes 20 millones de pesos (4.750.000 libras esterlinas), con descuento del $15 \%$, interés redituable del $6 \%, 2 \%$ de comisión sobre el valor nominal para los intermediarios extranjeros y $1 / 2 \%$ para cada uno de los negociadores colombianos.

El empréstito de 1824 llegó al país en barras de oro, por el puerto de Cartagena y de allí se trasladó a la Casa de la Moneda en Bogotá 
para su amonedación, lo que generaba una utilidad adicional (ramo reservado), otra parte se despachó para operaciones comerciales a Jamaica a nombre de Juan Francisco Infanson, y otra quedó a disposición del Ministro en Londres.

Con toda probabilidad, el buen nombre de los negociadores quedó reestablecido, sin embargo, se acusaba al Gobierno de incompetencia por permitir que los intereses se contaran desde una fecha anterior a la firma del contrato y por permitir el cobro de intereses por el crédito global antes de haberse recibido la última cuota del anterior. Pero este tema no quedaría completo y fue mucho lo dicho y sugerido en relación con la velocidad con que la administración gastó los $\$ 30.000 .000$ que había decretado el Congreso (Bushnell, 1985, p. 109). Según el decir del general Joaquín Posada Gutiérrez, testigo de aquella época: "En fin, despilfarros, errores, desaciertos se cometieron como siempre, desgracias sucedieron, mas no hubo delitos de peculado, no hubo estafas" (Barriga, 2010, p.668).

En informe que remitiera Santos Michelena, Cónsul General de Colombia en Inglaterra con fecha 31 de diciembre de 1826, aclara finalmente los dineros verdaderamente recibidos:

Cuadro 2

Estado demostrativo del producto del empréstito de $I 824$ y empleo que ha tenido

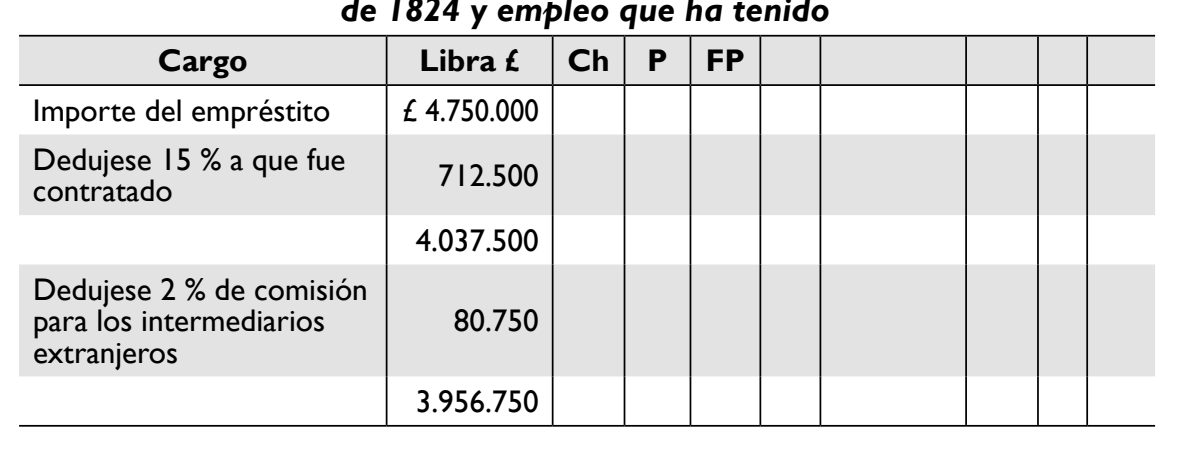

\begin{tabular}{|c|c|c|c|c|c|c|c|c|}
\hline Cargo & Libra $t$ & Ch & $\mathbf{P}$ & FP & Libra $t$ & Ch & $\mathbf{P}$ & FP \\
\hline \multirow[t]{2}{*}{$\begin{array}{l}\text { Gastos de B.A. Godschmi- } \\
\text { dt y Cía }\end{array}$} & 5.192 & 16 & 10 & & & & & \\
\hline & 3.951 .557 & 3 & 2 & & & & & \\
\hline \multirow[t]{2}{*}{$\begin{array}{l}4 \text { dividendos ( } 3 \% \text { semes- } \\
\text { tral } \times 728 \text { días/180) }\end{array}$} & 576.458 & II & 10 & & & & & \\
\hline & 3.375 .098 & 11 & 4 & & & & & \\
\hline $\begin{array}{l}\text { Más: Intereses devengados } \\
\text { a favor }\end{array}$ & 29.282 & 16 & 3 & $3 / 4$ & & & & \\
\hline $\begin{array}{l}\text { Saldo líquido para entrar a } \\
\text { la Hacienda de Colombia }\end{array}$ & & & & & 3.404 .381 & 7 & 7 & $3 / 4$ \\
\hline $\begin{array}{c}\text { Relativo a pendientes } \\
\text { del empréstito } \\
\text { anterior }\end{array}$ & $E$ & Ch & $\mathbf{P}$ & $\mathbf{F p}$ & & & & \\
\hline \multicolumn{9}{|l|}{$\begin{array}{l}\text { Entregas hechas por He- } \\
\text { rring, Graham y Powels }\end{array}$} \\
\hline En 30 de abril de 1824 & 82.500 & & & & & & & \\
\hline En 7 de junio de 1824 & 41.000 & & & & & & & \\
\hline En 6 de agosto de 1824 & 869 & 15 & & & & & & \\
\hline \multirow[t]{2}{*}{ En 29 de julio de 1825} & 20.297 & 2 & 5 & & & & & \\
\hline & 145.296 & 17 & 5 & & & & & \\
\hline \multirow[t]{3}{*}{$\begin{array}{l}\text { Menos: Gastos que no han } \\
\text { sido reembolsados }\end{array}$} & 384 & 10 & & & & & & \\
\hline & & & & & 144.912 & 7 & 5 & \\
\hline & & & & & $\begin{array}{r}3 . \\
594.293\end{array}$ & & 15 & $3 / 4$ \\
\hline \multicolumn{9}{|l|}{$\begin{array}{l}\text { Tres dividendos que no } \\
\text { han sido pagados }\end{array}$} \\
\hline En 9 de octubre de 1824 & 61.500 & & & & & & & \\
\hline En 30 de abril de 1825 & 61.500 & & & & & & & \\
\hline \multirow[t]{4}{*}{ En 10 de octubre de 1825} & 61.500 & & & & & & & \\
\hline & & & & & 184.500 & & & \\
\hline & & & & & 3.549 .293 & 15 & & $3 / 4$ \\
\hline & & & & & & & & \\
\hline
\end{tabular}

Samuel Leónidas Pérez Grau 


\begin{tabular}{|c|c|c|c|c|c|c|c|c|c|}
\hline Data & $E$ & Ch & $\mathbf{P}$ & Fp & & & & & \\
\hline \multicolumn{10}{|l|}{$\begin{array}{l}\text { Letras giradas por el Se- } \\
\text { cretario de Hacienda }\end{array}$} \\
\hline $\begin{array}{l}\text { Hasta II de febrero remi- } \\
\text { tidas en marzo }\end{array}$ & Ł 907.458 & 7 & 8 & $3 / 4$ & & & & & \\
\hline $\begin{array}{l}\text { Relativo a pendientes } \\
\text { del empréstito } \\
\text { anterior }\end{array}$ & & $t$ & $\mathrm{Ch}$ & $\mathrm{P}$ & Fp & $t$ & $\mathrm{Ch}$ & $P$ & $\mathrm{Fp}$ \\
\hline \multicolumn{10}{|l|}{$\begin{array}{l}\text { Listado de letras presenta- } \\
\text { das por Herring, Graham } \\
\text { y Powels }\end{array}$} \\
\hline $\begin{array}{l}\text { Letras giradas desde Cara- } \\
\text { cas................ } \mathrm{N}^{\circ} 2\end{array}$ & 42.988 & 12 & 5 & & & & & & \\
\hline $\begin{array}{l}\text { Letras giradas desde Saint } \\
\text { Thomas........ } \mathrm{N}^{\circ} 3\end{array}$ & 137.600 & 10 & & & & & & & \\
\hline $\begin{array}{l}\text { Letras giradas desde Phila- } \\
\text { delphia............ } \mathrm{N}^{\circ} 4\end{array}$ & 303.013 & 9 & 10 & & & & & & \\
\hline $\begin{array}{l}\text { Letras giradas desde } \\
\text { Kingston.............. } \mathrm{N}^{\circ} 5\end{array}$ & 164.530 & 16 & 5 & & & & & & \\
\hline $\begin{array}{l}\text { Dinero y pastas enviados a } \\
\text { Colombia..... } N^{\circ} 6\end{array}$ & 810.324 & 12 & 2 & & & & & & \\
\hline $\begin{array}{l}\text { Municiones enviadas a } \\
\text { Colombia.......... } \mathrm{N}^{\circ} 7\end{array}$ & 82.077 & 9 & 8 & & & & & & \\
\hline $\begin{array}{l}\text { Envíos varios hechos a } \\
\text { Colombia.......... } \mathrm{N}^{\circ} 8\end{array}$ & 3.151 & 9 & & $1 / 2$ & & & & & \\
\hline $\begin{array}{l}\text { Varias letras giradas por el } \\
\text { gobierno...... } \mathbf{N}^{\circ} 9\end{array}$ & $5.74 I$ & 3 & 5 & $1 / 2$ & & & & & \\
\hline $\begin{array}{l}\text { Libranzas giradas para } \\
\text { entregas en efectivo en } \\
\text { la secretaría de Colom- } \\
\text { bia................ } N^{\circ} 10\end{array}$ & 12.390 & 12 & 4 & & & & & & \\
\hline \multirow[t]{2}{*}{ Envío a New York } & 72 & 15 & 1 & & & & & & \\
\hline & & & & & & 2.469.359 & 8 & II & $3 / 4$ \\
\hline $\begin{array}{l}\text { Valor de los Certificados } \\
\text { listados...... } \mathrm{N}^{0} \mathrm{II}\end{array}$ & & & & & & 371.383 & 5 & & \\
\hline $\begin{array}{l}\text { Gastos de legacio- } \\
\text { nes.......... } \mathrm{N}^{\circ} 12\end{array}$ & & & & & & 9.343 & 4 & I & \\
\hline $\begin{array}{l}\text { Adeudado a la casa Golds- } \\
\text { chmidt........ } \mathrm{N}^{\circ} 13\end{array}$ & & & & & & 402.099 & 10 & 2 & \\
\hline $\begin{array}{l}\text { Amortizado de } 124.050 \\
\text { de vales......... } \mathrm{N}^{\circ} 14\end{array}$ & & & & & & 102.607 & 16 & 9 & \\
\hline
\end{tabular}

\begin{tabular}{|c|c|c|c|c|c|c|c|c|c|}
\hline $\begin{array}{l}\text { Relativo a pendientes } \\
\text { del empréstito } \\
\text { anterior }\end{array}$ & & $\epsilon$ & $\mathrm{Ch}$ & $P$ & $\mathrm{Fp}$ & $\epsilon$ & $\mathrm{Ch}$ & $P$ & $\mathrm{Fp}$ \\
\hline \multicolumn{10}{|l|}{$\begin{array}{l}\text { Tres dividendos que no han } \\
\text { sido pagados }\end{array}$} \\
\hline En 9 de octubre de 1824 & 61.500 & & & & & & & & \\
\hline En 30 de abril de 1825 & 61.500 & & & & & & & & \\
\hline \multirow[t]{3}{*}{ En 10 de octubre de 1825} & 61.500 & & & & & & & & \\
\hline & & & & & & 184.500 & & & \\
\hline & & & & & & 3.549 .293 & 15 & & $3 / 4$ \\
\hline Londres, 31 de julio de 1826 & & & & & & & & & \\
\hline \multicolumn{10}{|c|}{$\begin{array}{l}\text { Ch= Chelín }(1 \text { libra }=20 \text { chelín }) \\
P=\text { Penique }(1 \text { chelín }=12 \text { peniques }) \\
\text { FP= Fracción de peniques }\end{array}$} \\
\hline
\end{tabular}

Pero los capitales llegados a Colombia nunca fueron destinados a actividades de fomento agrícola o industrial, como había propuesto el ilustre Secretario de Hacienda, sino que se dedicaron al pago de la deuda doméstica a acreedores nacionales, el mantenimiento de los gastos del Ejército y del Congreso y el funcionamiento de las Tesorerías. El siguiente cuadro muestra la forma como fue distribuido el empréstito.

Cuadro 3

Distribución del emprésito

\begin{tabular}{l|r|r}
\hline Ramos & \multicolumn{1}{|c|}{ Pesos } & \multicolumn{1}{c}{$\%$} \\
\hline Deuda doméstica y sueldos atrasados & 1.018 .158 & 37,37 \\
\hline Tesorerías provinciales & 662.400 & 24,31 \\
\hline Gastos de guerra & 447.905 & 16,44 \\
\hline Congreso & 229.433 & 8,42 \\
Casas de Moneda & 154.830 & 5,68 \\
Tabaco & 137.000 & 5,03 \\
Varios & 72.536 & 2,66 \\
\hline Fletes & 2.623 & 0,10 \\
\hline TOTAL & 2.724 .885 & 100,00 \\
\hline
\end{tabular}

Samuel Leónidas Pérez Grau 


\section{Los gastos de la guerra}

El estado de guerra se mantuvo hasta 1825. El Congreso de 1824 aprobó una leva de 50.000 hombres solicitada por elVicepresidente en prevención a la versión de que habían zarpado barcos de guerra españoles desde Cádiz a América y a las necesidades de la guerra en el Perú. Calculada la población de entonces en unos 2.664.400, el cumplimiento de esta leva habría elevado el tamaño del ejército a más del $2 \%$ de dicha población. Los resultados del ejército libertador después de la toma de Trujillo por Bolívar en II de marzo de 1824 hicieron que se le considerara innecesaria.

El recaudo total de las rentas del año $1824-1825$ fue de $\$ 6.1196 .725$, una suma muy inferior a las necesidades de gasto de un Estado que subsidió la guerra de liberación del Virreinato del Perú y de la Audiencia de Charcas (Bolivia). El pago de la deuda extranjera ya representaba el $2,15 \%$ del gasto y esta cifra estaba muy lejos de satisfacer su servicio. A esto se unieron los levantamientos, las guerras civiles y las amenazas de reconquista. Los gastos de la Secretaría de Guerra y Marina de 1825-1826 ascendieron a $\$ 5.220 .518$ (43\%) seguidos por los pagos de intereses causados por la deuda externa y a un fondo de amortización de $\$ 2.100 .000$ (17,3\%). Los gastos de las otras tres secretarías ascendieron a $\$ 1.175 .302$, con lo cual en este año quedó un sobrante de $\$ 3.657 .560$.

Casi las tres cuartas partes del gasto del año fiscal 1825-1826 estaban representados en gastos militares (Bushnel, 2008, p. 122) y, aún en 1826-27, los gastos del ejército y la marina alcanzaron el $62 \%$. Era entonces indispensable gastar todo lo que pudiese la República para defensa del país, pues de no hacerlo, podría ser víctima de invasiones del enemigo con poder superior al suyo.Así, los gastos estatales tendían a ser mayores que los ingresos producidos por los rubros fiscales antiguos (Martínez, 2008, p. 148).
Al mismo tiempo, el problema del año fiscal 1825-1826 era agravado por el aumento exagerado de los gastos bajo el régimen republicano: dietas de los legisladores, gastos de los agentes diplomáticos, aumentos de cortes de justicia y la nómina de funcionarios ejecutivos (Martínez, 2008, p. 169). En 1826, se presupuestaron sueldos para 7 generales en jefe, 9 de división y 21 de brigada, más 69 coroneles y 122 tenientes coroneles. Se agregaron los de la oficialidad inferior y los del personal administrativo. Los gastos del departamento de guerra incluían los sueldos y vestuario del Estado mayor, la fuerza veterana, las milicias, los pensionados e inválidos, las cuatro compañías de maestranza, los empleados en las obras de fortificación de ocho plazas de guerra, los hospitales militares, la fábrica de pólvora, la reposición de parques, la provisión de caballos y sus raciones.

El I 8 de abril de 1826 es promulgada la primera Ley Orgánica Militar que define la Fuerza Armada Nacional compuesta por la fuerza marítima y la terrestre y la distingue de la milicia nacional de carácter voluntario. Define los cuerpos básicos (infantería, caballería, artillería e ingenieros). Establece la atribución del Congreso para fijar anualmente el tamaño del ejército permanente y la conscripción repartida ente todas las intendencias, provincias, cantones y parroquias. Señaló para entonces la existencia de hasta 20 generales efectivos y hasta 30 coroneles. Cada departamento militar, correspondiente al ordenamiento territorial, contó con su comandante general y su estado mayor. La milicia auxiliar se formaba con sus tres cuerpos de infantería, caballería y artillería en los cantones. La milicia cívica compuesta por ciudadanos voluntarios dispuestos a servir y defender la patria solamente era formada en las villas y parroquias.

La infantería, toda armada con fusiles, se dividía en 25 batallones de línea y 5 ligeros y el Gobierno ordenó que cada uno tuviese 8 
compañías. Cada batallón contaba con un comandante, un mayor, 2 ayudantes, I abanderado, cirujano, capellán armero, tambor mayor y 7 gastadores. Cada compañía, de cazadores, granaderos o fusileros, constaba de 100 plazas y 4 oficiales (la de cazadores 5). La caballería armada de lanzas se dividía en 24 escuadrones, 18 de línea, lanceros o dragones y 6 de húsares, cada escuadrón de 2 o de 3 compañías. Las compañías de tácticas modernas contaban con 80 plazas y 4 oficiales. La artillería, descontando los obreros, se componía de 20 compañías de a 100 plazas y 5 oficiales. El Gobierno contaba con una guardia de 10 batallones de infantería compuestos por 2 brigadas y 6 de caballería.

\section{La derogación de la contribución directa}

Durante tres años consecutivos se había venido presentando un fuerte movimiento en el Congreso que intentaba abolir completamente la contribución directa y restaurar en su sitio la alcabala, por lo que frecuentemente el Vicepresidente se sentía obligado a solicitar poderes especiales al Congreso para disminuir el valor liquidado cuando se presentaban evidencias de una menor producción que la presuntiva. El Vicepresidente esperaba que algún día el Gobierno tuviera suficientes datos económicos fidedignos para que el Congreso pudiese estimar cada año las necesidades fiscales de la Nación y fijara entonces la tasa anual de tributación directa (Bushnell, 1985, p. 108).

Las mismas dificultades financieras impedían el establecimiento del sistema burocrático completo, tal como puede apreciarse en párrafos como el siguiente tomado de los Escritos Económicos de don Salvador Camacho Roldán (1976, p.23):

La necesidad no puede ser explotada cuando se requieren recursos extraordinarios en una época de crisis. El aumento de la cuota del impuesto indirecto reduce el consumo del producto gravado y no aumenta los rendimientos totales de aquel. La contribución indirecta no podría salvar a un país en las épocas de los grandes conflictos. El impuesto indirecto no puede proveer los gastos extraordinarios de un país y sin la contribución directa solo se puede atender a esta clase de erogaciones por medio del empréstito; del empréstito que es el cáncer de los Estados, el sepulcro de los capitales, el aliciente de la dilapidación de los gobiernos y el pábulo a la ociosidad de los ricos egoístas que encuentran en ellos una manera segura de colocar su dinero a interés (Restrepo, 2010, p. 84)

Bajo la legislatura de 1826 tiene lugar el reconocimiento y fundación de la cuenta del Crédito Público mediante la Ley del 22 de febrero de 1826. También, la Ley del 13 de marzo de 1826, revisa los derechos de importación reduciéndolos a un único gravamen, denominado derecho de importación.

Un poco más tarde, en esta legislatura se establecen las administraciones de las contribuciones directas, diferenciando entre la contribución territorial sobre los predios rústicos, la urbana sobre los alquileres de las casas y la personal sobre los salarios de todos los oficios, artes y ocupaciones. En los departamentos del centro de Colombia, este nuevo esfuerzo fiscal pareció avanzar, pero los movimientos políticos que trastornaron el orden entre los venezolanos, afectaron a todos los ramos de la administración, dando un golpe mortal a las rentas nacionales y el crédito de la República. El Libertador en su marcha por Boyacá y Venezuela, no escuchó más que quejas contra el nuevo impuesto y el deseo de retornar a las contribuciones indirectas. Instruido el Vicepresidente, decretó el 7 de diciembre de 1826 la suspensión de la contribución directa y del cobro de patentes y reestableció la antigua carga comercial alcabalera del 15 \% sobre las mercancías transadas (Martínez, 2008, p. I58). 


\section{La flexibilización de los derechos aduaneros}

La Ley del 13 de marzo de 1826, revisa los derechos de importación reduciéndolos a un único gravamen, denominado derecho de importación. Las mercancías importadas serán clasificadas en seis clases: hojalata, textiles, sombreros, sedas y encajes, quincallería y muebles y ropa de hombre o de mujer, las cuales serían gravadas según la procedencia del buque, su bandera y la clase mercantil, ad valorem.

\section{Cuadro 4}

\begin{tabular}{|c|c|c|c|}
\hline \multicolumn{4}{|c|}{ Carga de exportación de productos nacionales } \\
\hline & \begin{tabular}{|c} 
Ley del \\
29 de septiembre \\
de $|82|$
\end{tabular} & $\begin{array}{l}\text { Ley del } \\
10 \text { de julio de } \\
\text { I824 }\end{array}$ & $\begin{array}{l}\text { Ley del } \\
13 \text { de marzo de } \\
1826\end{array}$ \\
\hline Tarifa básica & $5 \%$ & $4 \%$ & $4 \%$ \\
\hline Café & Libre & $6 \%$ & Libre \\
\hline Azúcar & Libre & $4 \%$ & $4 \%$ \\
\hline Aguardiente & Libre & $4 \%$ & $4 \%$ \\
\hline Cueros & $10 \%$ & $10 \%$ & $10 \%$ \\
\hline Cacao & $10 \%$ & $15 \%$ & $10 \%$ \\
\hline Añil & $10 \%$ & $5 \%$ & $5 \%$ \\
\hline Mulas & $15 \% *$ & $20^{*}$ & $20^{*}$ \\
\hline Caballos & $15 \% *$ & $16^{*}$ & $16^{*}$ \\
\hline Ganado & $121 / 2^{*}$ & $121 / 2^{*}$ & $12 \mathrm{I} / 2^{*}$ \\
\hline Oro amonedado & $3 \%$ & $3 \%$ & Libre \\
\hline Plata amonedada & Prohibida & Prohibida ** & Libre \\
\hline Algodón & Libre & Libre & Libre \\
\hline Arroz & $5 \%$ & Libre & Libre \\
\hline Maíz & $5 \%$ & Libre & Libre \\
\hline Quina & $5 \%$ & Libre & Libre \\
\hline Manufacturas & $5 \%$ & $4 \%$ & Libre \\
\hline
\end{tabular}

*Su exportación podía ser prohibida a discreción del Ejecutivo

** Únicamente en los puertos de Panamá y Guayaquil donde se permitía la exportación a la tasa del $3 \%$

$$
\text { Fuente: Bushnell, 1985, p. } 197
$$

Al examinarse las tarifas aduaneras que estableció la Gran Colombia, se encuentra que la importación de los productos que ya se producían o aquellos que tenían posibilidades de ser producidos en el país, fue gravada de manera severa respecto a los que no se producían, o por tratarse de insumos indispensables para la producción nacional era conveniente no encarecerlos con impuestos aduaneros muy altos (Restrepo, 2010, p. 88). Los zapateros, ebanistas y similares fueron tratados con algo más de consideración en la legislación que los tejedores cuyos productos no eran tanto del consumo popular. El ejército, que era el principal consumidor particular de textiles, prefería muchas veces los productos británicos.

Este sistema de tarifas relativamente liberal, hicieron crecer las importaciones colombianas en forma sostenida entre 1821 y 1825 , período en que la demanda extranjera de café y cacao permanecía relativamente estacionaria mientras que la producción de plata y oro no era posible de aumentar rápidamente, por lo que las importaciones llegaron a superar ampliamente a las exportaciones, dando lugar a una balanza comercial desfavorable.

También se trató de favorecer el desarrollo de la marina mercante colombiana estableciendo descuentos especiales de aduana y de derechos de tonelaje a las mercancías que llegaban en buques de bandera colombiana. Pero mucho más importante fue la preferencia del $5 \%$ menos acordada en Cúcuta a las mercancías traídas directamente a Colombia desde los puertos europeos, ya hubieran sido extranjeros o nacionales, pues tenía como propósito poner fin a las intermediaciones propiciadoras del contrabando desde los puertos de las Antillas. 
El tratamiento preferencial dado a la mercancía transportada en naves colombianas se hizo extensivo a los barcos de Perú, Chile y la América Central, por razones de solidaridad hispanoamericana; pero luego fue exigido por la Gran Bretaña como condición para poder firmar un acuerdo comercial en 1825, lo que a su vez obligó concederlo también a los Estados Unidos de conformidad al principio de la nación más favorecida según rezaban los términos de un acuerdo comercial previo (Bushnell, 1985, p. 194).

El siguiente cuadro pretende mostrar la evolución del impacto de los derechos aduaneros en el caso de la tan usual mercancía de importación, los tejidos de algodón, entre 1821 y 1829:

\section{Cuadro 5}

\section{Derechos (\%) que pagan las mercancías de la $2^{a}$ clase}

\begin{tabular}{l|r|r|r|r|r|r}
\hline Concepto & $\begin{array}{r}\text { Tarifa } \\
1821\end{array}$ & $\begin{array}{r}\text { Tarifa } \\
1823\end{array}$ & $\begin{array}{c}\text { Tarifa } \\
1826\end{array}$ & $\begin{array}{r}\text { Tarifa } \\
1828\end{array}$ & $\begin{array}{r}\text { Tarifa } \\
1829\end{array}$ \\
\hline Producidas en Inglaterra y procedentes de ella \\
\begin{tabular}{l|r|r|r|r} 
En barco nacional o en barco ingles después \\
de 1825
\end{tabular} & 10 & 10 & 10 & 17,5 & 18,5 \\
$\begin{array}{l}\text { En barco extranjero, o en barco inglés antes } \\
\text { de 1825 }\end{array}$ & 17,5 & 17,5 & 17,5 & 22,5 & 22,5 \\
\hline Producidas en Inglaterra o en otro país no asiático y procedentes de las Antillas \\
\hline $\begin{array}{l}\text { En barco nacional o en barco inglés después } \\
\text { de 1825 }\end{array}$ & 17,5 & 17,5 & 17,5 & 22,5 & 18,5 \\
$\begin{array}{l}\text { En barco extranjero, o en barco inglés antes } \\
\text { de 1825 }\end{array}$ & 22,5 & 22,5 & 22,5 & 27,5 & 22,5 \\
\hline
\end{tabular}

\section{La fundación de la deuda pública}

Preocupado el Vicepresidente por la situación de endeudamiento desde comienzos de 1825 venía clamando por la fundación contable de la deuda pública hasta lograr que en 22 de febrero de 1826 el Congreso decretara la Ley de Crédito Público en la que se ordenó abrir un libro de la deuda nacional e incorporar a la hacienda nacional la oficina de registro de varios actos civiles, nombrar una Comisión de Crédito Nacional encargada de llevar las cuentas y administrar los fondos destinados al pago de los réditos de la deuda extranjera y la doméstica, a la vez que se autorizó recaudar una contribución especial para auxiliar el pago de los intereses de la deuda externa, en cuyo efecto, cada cantón debía formar una junta de repartimiento la cual asignaría a cada padre de familia lo que le tocase, según su riqueza y en el rango de I a 1000 pesos.

Como deuda a cargo de la Nación, fueron reconocidas las siguientes cantidades:

- 2.000.000 libras esterlinas contratadas en París por Francisco Antonio Zea desde marzo de 1822 , al $6 \%$ anual de réditos.

- 4.750 .000 libras esterlinas (unos 20 millones de pesos) contratadas en Calais por Manuel Antonio Arrubla y Francisco Montoya desde el 14 de abril de 1824 , al $6 \%$ anual de réditos.

- 1.181.407 pesos de la deuda glosada desde la primera época de la transformación política de las provincias y liquidada por la Comisión de Liquidación, creada el 9 de mayo de 1825 y establecida en Bogotá, con las cantidades que aún faltan por glosar y liquidar al $5 \%$.

- 8I4.7I0 pesos del empréstito interno ordenado por la Ley del 25 de julio de 1823 para cubrir los haberes militares de las tropas de Apure, al $5 \%$ anual de réditos.

- El faltante por pagar de los 5.458 .600 pesos de haberes militares ordenados por la Ley del 28 de septiembre de 1821 , al $3 \%$ anual de réditos.

- El faltante por pagar de la mitad de los sueldos retenidos a civiles y militares por el decreto del Presidente del 14 de septiembre de 1819 al $3 \%$ anual de réditos. 
- El tercio de los sueldos retenidos a los mismos empleados, por la Ley del 8 de octubre de $182 \mid$ al $3 \%$ anual de réditos.

- Los principales a censo que fueron trasladados en todas las épocas de la revolución por los gobiernos republicanos, al $3 \%$ anual de réditos.

- La suma reconocida por el Acta de Independencia de Panamá, al $3 \%$ anual de réditos.

Para el pago de los réditos y la gradual desamortización de la deuda extranjera se destinarían en adelante:

- Todo el producto líquido de la renta de Tabacos.

- La octava parte del producto de las Aduanas.

- Todo el producto de la venta de las tierras baldías, de los arrendamientos de minas, $y$

- Los principales de las capellanías que se redimieran en dinero en efectivo.

Para el pago de los réditos de la deuda interior se destinarían en adelante, las rentas de las fincas y bienes confiscados, la renta de los bienes de mayorazgos y de los bienes de temporalidades, el producido por remates de bienes de obras pías o de manos muertas, el producto líquido de la renta del papel sellado, de la anotación de hipotecas y de registro de escrituras, el noveno de diezmos destinado a consolidación, el $10 \%$ de las rentas municipales y otros ingresos menores.

En realidad, el pago de los principales recibidos en préstamo nunca fue pagado durante la Gran Colombia y cuando hubo pago de intereses, ellos fueron deducidos de cada nuevo o parte de préstamo tramitado. Colombia, al igual que el resto de los países latinoamericanos, excepto Brasil, dejó de atender la deuda a partir de 1927.
Fue mucho después de la disolución del proyecto republicano, cuando los únicos delegados asistentes a Bogotá, Lino de Pombo por Colombia y Santos Michelena por Venezuela suscribieron en 23 de diciembre de 1834 la Convención que distribuyó la deuda grancolombiana, en proporción a su número de habitantes, así:"en cada cien unidades se hace cargo la Nueva Granada de cincuenta unidades; Venezuela de veinte y ocho y media; y el Ecuador se hará cargo de veintiuna y media", lo que correspondió respectivamente a 51 millones de pesos asignados a la Nueva Granada, 29 millones a Venezuela y 22 millones a Ecuador. En consecuencia, una vez dividida la deuda entre los tres países, la Ley del 20 de abril de 1938 fundó un nuevo estado de la deuda pública (Villaveces, 2007, p. 14).

\section{EL ESCENARIO DE CRISIS}

Los informes del Secretario de Hacienda de 1825 y 1826 ante el Senado anunciaban el escenario de crisis financiera en que poco a poco iba entrando el país. A finales de 1825 , el funcionario advertía: Si la (reforma) del (3 de agosto) del año 1824, que arregla la administración de hacienda en todos sus ramos, hubiese tenido su completa ejecución, quiero decir, si todos los empleados subalternos, los jefes de las oficinas se hubieran contraído a desempeñar con celo los encargos que se les hacen y cumplir las órdenes que les fueron comunicadas, esta exposición habría podido hacerse antes y tendría mayor exactitud. (Del Castillo, 1826, p.46)

\section{En el siguiente presupuesto,}

"He calculado muy por bajo los productos de las rentas si se adoptan las reformas propuestas. Tengo bastante seguridad de que no he exagerado... en que he omitido algunos productos, porque aunque 
seguros en sí, son inciertos en la cuantía y he dejado otros iguales a los del año anterior, más no debe esperarse, que ellos se realicen, si no se hacen las mejoras y reformas propuestas, si no se da más fuerza a la administración, si no se deja al Ejecutivo el derecho de remover a los empleados a propuesta de los jefes, siempre que no desempeñen fielmente sus funciones y dejen de merecer la confianza que se puso en ellos al nombrarlos. (Del Castillo, I826, p.47)

\section{Presupuesto de ingresos del año de 1826}

\section{Cuadro 6}

Planilla de los ingresos que se calcula tendrá la hacienda nacional en el próximo año, si se adoptan las mejoras propuestas en la memoria que se presenta al Congreso

\begin{tabular}{|l|r|l|r|}
\hline \multicolumn{4}{|c|}{ en la memoria que se presenta al Congreso } \\
\hline Importación & $\$ 2.500 .000$ & Suma del frente & 100.000 \\
\hline Exportación & 600.000 & Aguardientes & 300.000 \\
\hline Toneladas & 40.000 & Diezmos & 100.000 \\
\hline Consumo & 200.000 & Correos & 10.445 \\
\hline Tabacos & 4.000 .000 & Venduta & 204.472 \\
\hline Urao & 10.000 & Varios ramos pequeños & 4.477 \\
\hline Rapé y tabaco en polvo & 25.000 & Tierras & 2.402 \\
\hline Salinas & 300.000 & Multas & 500.000 \\
\hline Casas de moneda & 180.000 & Contribución personal & 600.000 \\
\hline Quintos de oro y plata & 50.000 & Ídem de casa & 2.000 .000 \\
\hline Fundición & 4.302 & Territorial & 11.794 .576 \\
\hline Escobilla & 2.799 & Suma total & \\
\cline { 2 - 3 } Productos de minas & 679 & & \\
\hline Papel sellado & 60.000 & J.M. DEL CASTILLO \\
\cline { 2 - 4 } & & Bogotá, 25 de diciembre I825 \\
\hline Suma a la vuelta & Fuente: Exposición del Secretario de Hacienda presentada al Congreso de 1826, p. I10
\end{tabular}

Y al remate del informe revelaba:

Así tan elevadas las rentas..., resulta todavía un deficiente... para cubrir el presupuesto de gastos. Este vacío debe llenarse como que es el objeto de vuestras deliberaciones (señores de Congreso) y a él han de dirigirse vuestros esfuerzos en la presente sesión. (Del Castillo, 1826, p.48).

\section{Presupuesto de gastos del año I 826}

Resumen del presupuesto de gastos de un año en cada uno de los departamentos de la administración de la República

\begin{tabular}{|c|c|c|}
\hline Departamento de Relaciones Exteriores & & $\$ 295.76207 \quad 17$ \\
\hline Departamento del Interior & & 621.4310100 \\
\hline Departamento de la Guerra & & 6.803 .2960100 \\
\hline Departamento de Marina & & $4.809 .07704 \quad 17$ \\
\hline $\begin{array}{l}\text { Departamento de Hacienda } \\
\text { Gastos de este departamento } \\
\text { Interés de la deuda } \\
\text { Fondo de amortización (। \%) }\end{array}$ & $\begin{array}{r}358.1420706 \\
1.800 .00000 \\
300.00000\end{array}$ & 2.958 .1420706 \\
\hline Suma total & & I5.487.70903 04 \\
\hline Bogotá, 25 de diciembre de 1825 & & \\
\hline
\end{tabular}

No obstante las anteriores advertencias, la situación general de la República se mantenía la misma al año siguiente, por lo que nuevamente el Secretario de Hacienda en su informe anual ante el Congreso, el 12 de mayo de 1827, expone:

...aunque me he contraído a indicar la organización que, a mi ver, conviene más a la hacienda nacional, me creo obligado (también) a proponer al congreso que se dedique a la organización de los otros ramos, porque sin ello puede todavía ser ineficaz la de la hacienda. Sobre todo la administración del ejército y la marina (que) la reclaman muy especial. Estos dos ramos causan los mayores consumos y en ellos hay más riesgo de que se hagan arbitrarios y fraudulentos. 
Hoy no se puede presentar a la nación un cuadro de las expensas del año anterior porque no existe hasta hoy la administración arreglada, que debiera haber elevado los datos para formarla. En consecuencia, con el estado de que han rendido las cuentas en el último año económico, acompaño solamente los presupuestos de gastos para el corriente. En ellos, se nota una considerable diferencia respecto de los del año anterior, la cual no solo consiste en el ahorro de algunos gastos, hecho con supresiones de empleos, oficinas $y$ pensiones y con reducciones de cuerpos militares y escuadra, sino que en el año anterior se presupuso lo necesario para la provisión de almacenes de objetos que deben existir y para el entretenimiento de una escuadra respetable que se ha desarmado. Si las cámaras tomaren este año en consideración los presupuestos, podrán explicarse y aclararse cualesquiera dudas por los respectivos secretarios del despacho y entonces haciéndose sentir más la necesidad del arreglo de la administración en todos sus ramos, podrán fijarse los gastos y consumos públicos. Para el perfecto arreglo y determinación de los gastos era de suma importancia el estado circunstanciado de los que se hicieron en el año precedente...

Tampoco debo dejar de hablar de las deudas con que está gravada la República, sin que estén reconocidas en la ley ni comprendida para el pago de sus intereses y amortización en la consolidada... Los acreedores han estrechado al gobierno en los días de sus mayores conflictos, porque es natural que introducida la desconfianza hayan temido perder lo que se les debe. El ejecutivo de su parte, sin desconocer la justicia de su reclamo, se ha encontrado sin medios de satisfacerles cuando no los ha tenido para los gastos precisos de la administración, pero ya no es posible dejar esta materia en la incertidumbre. La Republica es deudora, ella debe saber de cuánto lo es, y proveer de medios para el pago y si la ley determina los fondos o el modo de hacerlos, el ejecutivo dispondrá que se haga la liquidación con escrupulosidad y prontitud. (Del Castillo, I827, pp.47-48)

\section{Presupuesto de gastos del año 1827}

\section{Cuadro 8}

Resumen general de gastos en el año de 1827 en cada uno de los departamentos de la administración de la República

\begin{tabular}{|c|c|}
\hline Departamento de Relaciones Exteriores & $\$ 69.369$ \\
\hline Departamento del Interior & 526.886 \\
\hline Departamento de la Guerra & 4.307.797 \\
\hline Departamento de Marina (I) & 912.721 \\
\hline $\begin{array}{l}\text { Departamento de Hacienda (2) } \\
\text { Gastos de este departamento } \\
\text { Interés de la deuda } \\
\text { Fondo de amortización ( } \\
\text { ( \%) }\end{array}$ & 2.679 .047 \\
\hline Suma total & 8.495 .920 \\
\hline $\begin{array}{l}\text { (1) En el caso de que hayan de equiparse y armarse todos los buques de guerra de la } \\
\text { República, entonces el presupuesto del departamento de marina subirá a } 2.026 .422 \\
\text { pesos. } \\
\text { (2) En el [caso] de que el Congreso determine que queden subsistentes las supresio- } \\
\text { nes de algunas oficinas y la disminución de empleados decretada por El Libertadoro } \\
\text { en } 23 \text { de noviembre del año anterior el presupuesto de este departamento será de } \\
\text { la cantidad expresada, pero en el de determinarse lo contrario y que subsistan las } \\
\text { creadas por las leyes vigentes entonces subiría a } 632.732 \text { pesos. } \\
\text { Bogotá, I2 de mayo de } 1827 \text {, José M. Del Castillo }\end{array}$ & \\
\hline
\end{tabular}

Fuente: Exposición del Secretario de Hacienda presentada al Congreso de 1827, p.60

El tiempo pudo hacer que la parte legislativa o más bien la legislación tributaria se completase en la cuarta legislatura (abril de 1826), pero no ha podido suceder lo mismo con la parte administrativa, la más importante, la que lleva a efecto la primera y la única que puede decidir de su bondad. El Congreso Constituyente no pudo ocuparse de esta segunda parte, porque no pudo ni debió hacerlo todo. Encargó al ejecutivo los primeros arreglos y los hizo el Vicepresidente de la República por decretos y reglamentos de que dio cuenta al Congreso en cada año, proponiendo diferentes reformas como elementos para un arreglo definitivo... Se halla pues hoy el 
Congreso con materiales suficientes para la última mano a la obra, para decretar un plan general y bien combinado...y yo someto a su sabiduría las combinaciones de esta exposición. (Del Castillo, 1827, Pp.58-59)

\section{Cuadro 9}

Resumen de los ramos de ingreso y egreso de caudales que forman el tesoro nacional

\begin{tabular}{l|r|r|r}
\multicolumn{4}{c}{ forman el tesoro nacional } \\
\hline Ramos & \multicolumn{1}{c|}{ Ingreso } & \multicolumn{1}{c|}{ Egreso } & Disponible \\
\hline Aduanas & $\$ 5.688 .019$ & $\$ 260.168$ & 5.427 .851 \\
Casas de moneda & 142.151 & 0 & 142.151 \\
\hline Tabacos & 800.518 & 512.018 & 288.500 \\
Correos & 111.659 & 101.330 & 10.329 \\
\hline Tesorerías & 3.795 .488 & 6.596 .760 & $(2.801 .272)$ \\
\hline Tesorerías del Magdalena & 1.618 .534 & 1.455 .790 & 162.744 \\
Suma total & 12.156 .369 & 8.926 .066 & 3.230 .303 \\
\hline FUENTE: Exposición del Secretario de Hacienda presentada al Congreso de 1827.067
\end{tabular}

FUENTE: Exposición del Secretario de Hacienda presentada al Congreso de 1827, p.67

En esas ocasiones en que el Secretario de Hacienda de la República de Colombia informaba sobre situaciones de dificultad financiera, lo que explicaba como consecuencia de diversos factores tales como: la mala gestión de los funcionarios, la falta de reacción o reacción tardía o inadecuada ante las señales de alarma, la existencia de factores sociales muchas veces no tenidos en cuenta por los legisladores, factores económicos mal valorados, etc... no era válido aun suponer que no se contaba con suficiente margen de maniobra gerencial. Sin embargo, sea por lo que fuere, en todos los casos, las situaciones de insolvencia, desde el momento que se detectan, deben ser abordadas para darles una solución urgente.

De manera general, el deterioro financiero de cualquier proyecto organizacional casi nunca se produce de una forma repentina sino que él va apareciendo escalonada y progresivamente llevando lentamente a la organización a situaciones críticas. Siempre pudiera ser posible que una crisis financiera llegue a producirse de forma imprevista, inapelable o implacable independientemente de la gestión del desarrollo equilibrado que haya podido haberse estado implementando. Sin embargo, la experiencia indica que en todos los tipos de crisis los administradores afrontan la urgencia de abordar medidas de saneamiento que cada situación amerite.

De todos modos, debe reconocerse el esfuerzo que dedica Bolívar en sus últimos actos de gobierno al mismo problema que lo ha atormentado tanto tiempo, y así, se dedica todavía a otro proyecto para liberar la Gran Colombia del pesado fardo de la deuda (Brito, 1966. p.415).

Por su larga experiencia, Bolívar manejaba el principio de equilibrio presupuestal y la necesidad de minimizar excepciones de ley. La suspensión de pagos, como figura conciliadora, tiene como causa la insolvencia provisional o relativa del deudor, cuya finalidad es tratar de conseguir un acuerdo de los acreedores con el deudor que permita restablecer la normalidad de los pagos. En términos más jurídicos, la suspensión de pagos es un estado preliminar de la quiebra que se orienta por el amparo legal conferido al deudor en dificultad financiera, tratando de evitar la acumulación de embargos y ejecuciones individuales de los acreedores (García y García, 2000, p. 130 ).

En una situación de insolvencia el deudor que insta una suspensión de pagos debe haber terminado el procedimiento de reconocimiento o fundación de la deuda y a cambio del amparo deberá presentar un plan de viabilidad, que consiste en una oferta racional, real y posible de compromiso por adoptar medidas necesarias para solventar la situación de crisis.

La manera de responder a las decisiones concursales que propician 
los reclamos de los acreedores o la ley, para no dejarse arrastrar directamente hacia el embargo y posterior remate de los bienes, en sí mismas, no representan una solución de las crisis sino que su validez surge según la estrategia desplegada para usar los recursos jurídicos como pudiera ser la obtención del amparo legal que confiere la etapa de arreglos previos de todo proceso concursal solamente otorgable tras la solicitud de recomposición del deudor acompañada de la correspondiente terapia financiera que la avale.

El período 1827-1830 representa el desenlace de la crisis republicana. Aquí, parece Bolívar alguien que hablara ante sordos. En vano decreta penas rigurosas para los funcionarios que no cumplen con sus funciones, ordena prisión por deudas contra los contribuyentes morosos y remates contra sus bienes. La inercia lo paraliza todo en un pueblo "que a nadie paga ni paga nada". Con frecuencia revientan motines causados esencialmente por la miserable condición de las tropas. Sin recursos no es posible conjurarlos (Brito, 1966. p.376).

Después de resignar el mando, en 4 de mayo de 1830, el Libertador no puede ya constituir más deuda ni luchar contra su inevitable crecimiento especulativo. En su mensaje de despedida ante el Congreso constituyente, propone un expediente de política fiscal: el incentivo de exención de los tributos inherentes al ramo de minas durante diez años, y la oferta de reintegro del capital invertido si luego de hacerlas producir desisten de la empresa. Se deja abierta la posibilidad de que los acreedores trabajen dichas minas en compañía. Por otro lado, se recurre al expediente peligroso de ofrecer el reintegro del capital invertido si este no resulta suficientemente remunerativo, con lo cual la República asume la totalidad del riesgo y el inversionista no corre ninguno. No es la última vez que se admitirá este procedimiento.
Lo destacable del período 1827-1830, en materia de ingresos efectivos, es su decrecimiento a una tasa anual del $-10,9 \%$ siendo su masa monetaria de apenas $\$ 19.556 .45 \mathrm{I}$, distribuidos ahora entre Aduanas (36\%) y Empréstitos internos ( $18 \%$ ). Aunque levemente durante el período continúa observándose un incremento de los egresos por gastos militares de apenas $3 \%$, ahora suben más rápidamente los egresos por gastos civiles.

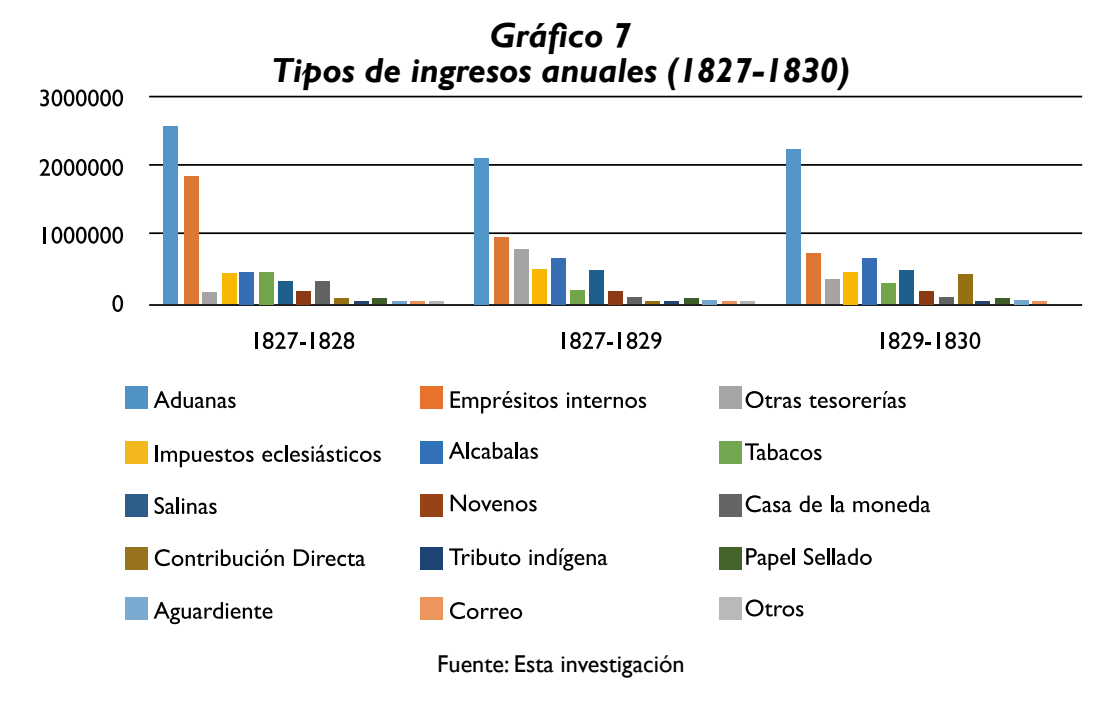

Los egresos totales del período 1827-1830 ascendieron a $\$ 24.399 .870$, repartidos entre egresos Militares (43\%), egresos Civiles (49\%) y el Servicio de la Deuda (8\%). 


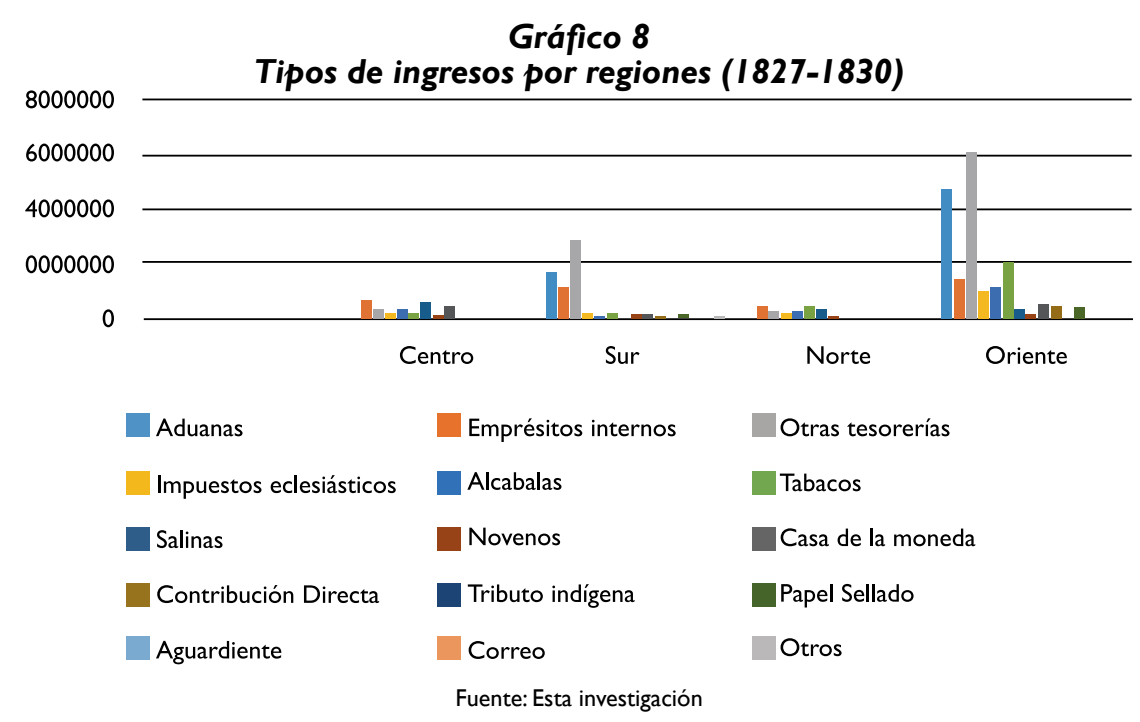

El período 1827-1830, presentaba Aduanas como los ingresos más altos la región Oriental (26\%), seguido de Otras tesorerías (33\%) y Tabacos (1 I \%). La región Sur tenía Otras tesorerías (42\%) como su mejor fuente, Aduanas (25\%) y Empréstitos internos (17\%). Luego la región Central con Empréstitos internos (2l \%), Salinas (20\%), Casa de Moneda (17\%), Otras tesorerías (12\%) y Alcabalas (II \%) y la región Norte con Aduanas (22\%), Tabacos (16\%), Empréstitos internos (16\%), Salinas (14\%) y Otras tesorerías (10\%).

Los gastos militares disminuyeron con motivo de la finalización de la Campaña del Sur pero se mantenían aún magnificados en la región Oriental en prevención a situaciones de conflicto ante los movimientos políticos regionales y desórdenes ciudadanos. Los gastos civiles se habían ido estabilizando y se mostraban crecientes en las regiones Norte y Oriental. Lo del Norte se explicaba por su sostenimiento de la administración de Panamá.

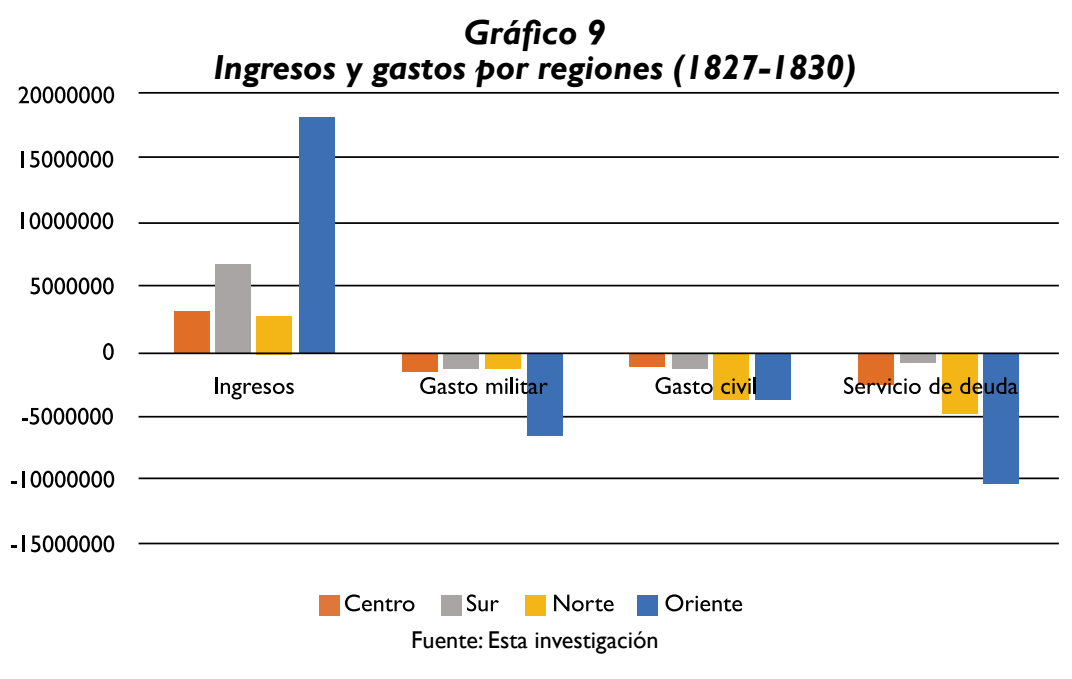




\section{Las soluciones que no se implementaron}

A su regreso de la campaña del Sur, el Libertador en Bogotá retoma la Presidencia de la República y el 23 de noviembre de 1826 promulga un primer decreto "con el objeto de remover todos los obstáculos que había tenido hasta el día la recaudación de los impuestos y contribuciones y de facilitar la cumplida observancia de las leyes fiscales" a la vez que levantar la pena de muerte decretada por el Decreto del 21 de febrero de 1822 para los empleados de Hacienda Nacional comprometidos en fraude o malversación de intereses públicos, cambiándola por penas de prisión hasta de 10 años, corriendo además con las costas del proceso (López Garavito, 1992, p.43).

Las medidas eran percibidas como extremas, tal vez como lo requería la situación, y disponían:

$1^{\circ}$ Todos los recaudadores de las rentas nacionales sin distinción de ramos, y cada uno en el cantón o distrito que esté a su cargo ejercerán toda la jurisdicción coactiva necesaria para llevar a puro y debido efecto el cobro de los impuestos y contribuciones.

$2^{\circ}$ En esta virtud los mencionados administradores y demás recaudadores, procederán contra la persona y bienes de los deudores, de plano y sin figura de juicio estrechándolos con prisiones y embargos de bienes suficientes a cubrir su deuda, los cuales se venderán en subasta pública, rematándose en el mejor postor, sin consideración a su valor, cuidando únicamente de sacar de ellos la suma debida.

$3^{\circ}$ En ningún caso se relajará la prisión mientras el deudor no quede solvente (Barret et al., 1961,Tomo III, pp.32-33). 
El mismo día, el Libertador Presidente de la República derogó la pena de muerte aplicable para los empleados de Hacienda comprometidos en fraude o malversación de los intereses públicos e invocando principios de ética y moral vigentes en todo tiempo y lugar, promulga nuevas penas:"para dar a la administración de Hacienda el movimiento activo, continuo $y$ eficaz que requiere para su prosperidad"....A tal efecto, dispone:

Artículo $5^{\circ} \mathrm{La}$ ineptitud de todos los empleados mencionados que se calificará por el hecho de no llenar los deberes de que se ha hecho mención, se castiga con la destitución del empleado. Artículo $6^{\circ}$ La negligencia $\circ$ aquella falta de diligencia que aplica a sus propios negocios un regular padre de familia con la destitución e inhabilitación. Artículo $7^{\circ}$ La connivencia o culpable deferencia con un subalterno negligente, o con un defraudador, se castigará irremisiblemente con diez años de presidio si no se probare al empleado parte en el fraude. Artículo $8^{\circ}$ Por la participación en el fraude $\circ$ por el fraude cometido solo por el empleado, sufrirá éste diez años de presidio, el perdimiento de todos sus bienes, si no tuviere hijos, y el de una tercera parte si los tuviere. (Barret et al., 196I,Tomo III, Pp.34-35)

Y todavía, ese atareado día el Libertador decreta:

Artículo $1^{\circ}$ Todo defraudador de las rentas del Estado queda sujeto a la pena de perdimiento de las mercaderías, géneros o efectos en que haga o pretenda hacer la defraudación y en la de presidio desde los seis hasta los diez años y respondiendo por las costas del proceso. Artículo $2^{\circ}$ Son defraudadores en el sentido del artículo anterior a) Los que importaren, exportaren o internaren mercaderías, frutos y efectos extranjeros eludiendo su presentación en las aduanas para no pagar los derechos establecidos; b) Los que introdujeren por los puertos de la República mercaderías, frutos o efectos de prohibida introducción;c) Los que contra la prohibición de las leyes pretendan exportar furtivamente los metales prohibidos; d) Los cultivadores, vendedores y conductores de tabacos contra las instrucciones del ramo y sin los requisitos que ellas prescriben, $y$ e) Los destiladores clandestinos $y$ vendedores por menor de aguardientes sin las licencias que determina la ley. Artículo $3^{\circ}$ En la pena de perdimiento se comprende el buque, carruaje o caballería y la de los utensilios, vasijas y aparatos en que se cometa el fraude. Los encubridores, coautores y receptores del fraude están sujetos a las mismas penas. (Barret et al., 196I,Tomo III, pp.38-39)

Dos días después, el 25 de noviembre de 1826, Bolívar marcha con la élite de sus tropas a Venezuela. Ya llegado a tierras venezolanas, despliega otra frenética actividad con el ánimo de pacificar el país pero con la doble estrategia de la amenaza y de la conciliación. En primer lugar, el 7 de diciembre de 1826 inicia una gran contra-reforma fiscal decretando el restablecimiento del impuesto de la alcabala al mismo I5 \% en que estaba antes de I82I (Martínez, 2008, p. I62). El 24 de diciembre de 1826, decreta la medida proteccionista de prohibir la exportación de caballos, yeguas, asnos y mulas, en vista de que

nuestra agricultura no puede reponerse del atraso en que se halla por la escasez de ganado que dejó la guerra, se ha aumentado con la extracción de los que quedaban; y que no sólo se carece de los medios de llevar los frutos al mercado, sino aun de los de labrar la tierra. (Blanco y Azpurúa, 1978, Tomo XI, pp.65-66)

El 3 de enero recibe en Puerto Cabello el decreto de Páez que reconoce su autoridad, anula la convocatoria de un congreso sepa-

Samuel Leónidas Pérez Grau 
ratista y admite la de una convención grancolombiana "que se ocupe de las reformas reclamadas por los pueblos para decidir de la suerte de la República”.

Luego, en 4 de enero de 1827, el Libertador persuade a Páez de deponer su sublevación contra la Gran Colombia, a cambio de ser reconocido como jefe civil y militar de Venezuela. El Libertador y Páez se abrazan en Valencia y allí acaba aparentemente la disidencia, pero las discrepancias seguirán ahora entre Bolívar y Santander.

El 16 de enero decreta la suspensión de los salarios de empleados y militares que no estén prestando servicio activo, así como la de pensiones de retiro y gratificaciones que no se fundamenten a servicios efectivamente prestados, régimen del cual por razones humanitarias excluye las asignaciones a los inválidos militares (Barret et al., I96I, Tomo II, pp.83-84).

El 17 de enero de 1827, ya instalado en Caracas, a fin de armonizar los gastos con los ingresos, dispone la suspensión de todos los gastos que se tenga previsto realizar en las aduanas y que se redacte un informe sobre suma total de libramientos a cancelar a fin de ordenar su satisfacción según las cantidades ingresadas. Exige también informes sobre lo producido el año anterior por cada rubro de rentas, comparados con las estimaciones iniciales y las razones por las cuales no se hubiere obtenido la recaudación prevista (Blanco y Azpúrua, 1978, Tomo XI, p. 100). El 19 de enero decreta una reducción salarial de los militares.

El 23 de enero de 1827, también a través de José Rafael Revenga, manda al general Páez que en su condición de jefe superior de Ve- nezuela, ordene el pago de todas las cantidades que se deban a la Hacienda Pública en el plazo perentorio de ocho días, refiriéndose como ejemplo del retraso que impera en lo relativo a los ingresos el hecho de que para el primero de diciembre del año pasado los ciudadanos debieran a la aduana de La Guaira un total de 132.000 pesos (Blanco y Azpúrua, 1978, Tomo XI, pp. I01-102).

Es tarea casi imposible reordenar en pocos meses un aparato administrativo que casi no existe. Es de imaginar el desaliento del Libertador al tratar inútilmente de hacer funcionar para el bien de todos, una maquinaria en la que cada una de cuyas partes piensa solo en el provecho propio.

El 28 de enero de 1827 Bolívar está dispuesto a aplicar sin contemplaciones en Venezuela los decretos que promulgó antes de partir de Colombia, y así, por medio de su secretario José Rafael Revenga hace saber al secretario del Interior: "Los principales vicios que hasta ahora se han descubierto en la administración de estos departamentos, nacen de ineptitud y falta de celo de parte de los empleados". El Libertador por consiguiente, ha pedido también una lista nominal y crítica de todos. Así, espera S.E. no solo despedir a los que no merezcan sus destinos, sino proveer estos en los militares que tengan aptitud, y que a virtud de los adjuntos decretos de 16 y 19 del corriente quedan reformados (Blanco y Azpúrua, 1978, Tomo XI, p. I03).

El I3 de febrero del mismo año Bolívar promulga un decreto en el cual coloca tanto el primer como el segundo departamento de marina de Venezuela a las órdenes de un solo comandante, "consultando la economía en los gastos públicos” (Barret et al., 198I, Tomo II, pp.91-92). El mismo día escribe desde Caracas al general Mariano 
Montilla agradeciéndole los auxilios en hombres, pertrechos y numerario prestados para la marcha sobre Caracas, y le expresa:

En verdad, no sé cómo mantener las tropas que existen en estos departamentos. Por lo mismo, yo me ocupo casi exclusivamente en mejorar el sistema de hacienda con el objeto de aumentar las entradas y disminuir el fraude, que ha sido excesivo. (Blanco y Azpúrua, 1978, Tomo II, pp.55I-552)

El 6 de marzo de 1827 ya se dirige al general Urdaneta advirtiéndole que:

Por la secretaría o por el Estado Mayor recibirá Ud. la orden para reducir el batallón de Albión a 200 plazas. Igual medida se ha tomado con todos los demás cuerpos para ver si de este modo logramos desahogar el estado de sus enormes gastos. Conservando el cuadro con sus jefes y oficiales, será fácil llenarlo otra vez, siempre que hubiesen peligros que ahora no existen. (Lecuna, 1947, Tomo II, Pp.572-573)

\section{El 7 de marzo de 1827 decreta en Caracas:}

"Art. $1^{\circ} \mathrm{A}$ ninguno se le declarará derecho al haber militar o recompensa nacional sin que pruebe este derecho con listas de revista $\circ$ con certificación de los mismos jefes a cuyas órdenes inmediatas sirviese, y el grado militar que a la sazón tuviese y el cuerpo o compañía a que pertenecía, y nada conste en contra de dichas certificaciones al Jefe de la División o, en su defecto al Comandante Militar de la Provincia en que se hallase el cuerpo o compañía. (Barret et al., 1961, Tomo II, pp.96-97)

El 9 de marzo de 1827 expide norma en la cual impone el sistema de aranceles para las aduanas marítimas, y los distingue según las categorías de bienes a ser importados, y elimina el tributo de derechos por valor. En el parágrafo $2^{\circ}$ del artículo 12, eleva un cinco por ciento de los aranceles cuando los bienes se introduzcan por barcos extranjeros, a menos que algún tratado los dispense de ello. El parágrafo $4^{\circ}$ pauta que:

Serán libres de derechos de introducción todos los instrumentos de cirugía, matemáticas, ciencias naturales y de agricultura, los que tengan por objeto mejorar la navegación de los lagos y ríos, $y$ las manufacturas domésticas de lana o de algodón; los que sean necesarios para ejercer la profesión al artesano extranjero que venga a establecerse en el país; las plantas y semillas; los libros impresos, cualquiera que sea su encuadernación;y los mapas e imprentas.

Esta norma proteccionista de insumos necesarios para el fomento de las industrias, las artes y las manufacturas, es equilibrada por la inmediata, que veta el ingreso a los productos ibéricos:

Parágrafo $5^{\circ}$ Pero continúa prohibida bajo las penas que establecen las leyes, la introducción en nuestros puertos de todo producto o manufactura originaria de los dominios españoles; la del azúcar, de cualquier especie que sea, y la del tabaco que no se introduzca en polvo. (Barret et al., 1961, Tomo II, pp. I56-182)

En el mismo sentido, el 9 de marzo de 1827 se dirige desde Caracas al almirante Padilla, al cual manifiesta que:

No teniendo nada qué temer de los españoles por el estado de impotencia en que se hallan, $y$ ahora por las dificultades en que se encuentran de resultas de los acontecimientos de Portugal, he determinado disminuir en cuanto sea posible las fuerzas que guarnecen estos puertos, y aún creo que se hará lo mismo en toda Colombia. (Lecuna, 1947,Tomo II, pp.576) 
Y el II de marzo de 1827, a través de su secretario José Rafael Revenga, comunica al intendente del departamento de Venezuela:

Las necesidades de la tropa tienen en constante aflicción el ánimo de S.E.: en particular la condición de la oficialidad es miserable: aumenta mucho este pesar la observación de que los vicios que ha padecido la administración, al mismo tiempo que han sujetado a la mayor escasez a los servidores de la patria, han puesto en peligro el cobro de lo que se adeuda a la hacienda. (Blanco y Azpúrua, 1978, Tomo XI, pp. I70-I7I)

Ante el estallido de otra rebelión popular, el 28 de marzo informa Bolívar al general Rafael Urdaneta:

La miseria en que está el país, me obligó a sacar unas tropas de este departamento, y de resultas de esto tuve que sacar la guarnición de Valencia para Puerto Cabello, a fin de reemplazar a 200 granaderos que había mandado a Cartagena en el batallón Apure. La guarnición de Valencia, compuesta de dragones, artilleros y un piquete de Anzoátegui, se sublevó y se dispersó, temiendo que la embarcaran en Puerto Cabello. Un oficial se puso a la cabeza de los Dragones, $y$ ha tomado el camino a los Llanos en busca del general Páez. Los artilleros los ha prendido en Calabozo el general Iribarren. Yo he dado orden que fusilen a todos los rebeldes y cuatro que han venido aquí se fusilan hoy. Por la parte de Barcelona ha habido un motín de cuatro o cinco pueblos que pedían reformas y se habían negado a la obediencia del general Monagas; pero la verdadera causa es que les habían pedido las armas y municiones que estaban en sus manos, las que debían traer a la capital; $y$ ellos temieron que los agarrasen para el servicio, y aun los mandasen a Puerto Rico, como se decía. El general Mariño ha venido a Barcelona a apaciguar esa gente, y así lo ofrece hacer sin dificultad alguna. Yo le había mandado tropas a
Monagas para que los destruyera si no se habían rendido antes. El general Páez ha ido a los llanos a apaciguar esa gente, que estaba medio alarmada por consecuencia de las reformas. Me ha escrito que todo lo deja en el mejor estado posible y que su religión y su Dios soy yo. De manera que, aunque las cosas no están enteramente buenas, $y$ que el año 27 no puede ser muy tranquilo, sin embargo, se debe esperar que el orden y la ley vuelvan a tomar su influjo. Yo me he mostrado inexorable en estas circunstancias con respecto a todo, todo, todo. He mandado castigar de muerte a los criminales y meter en la cárcel a los deudores del Estado, mas los subalternos están bastante tibios en cuanto a cumplir lo que yo he ordenado. Sin embargo, lo poco que se haga bastará para darle energía al gobierno pues hace muchos años que aquí no hay más que indulgencias, y mi rigor hará buen efecto. He formado un consejo permanente para que juzgue todos los delitos militares; y yo mando cumplir las sentencias. No es creíble la relajación en que está todo. Necesitamos de una energía cruel para entonar el gobierno. (Lecuna, 1947, Tomo II, pp.597-60I)

El 2 de abril de 1827, ante la dificultad que presenta una adquisición de prendas militares muy pequeñas, instruye al general Bartolomé Salom:

Dé Ud. orden al comandante de Puerto Cabello que haga agrandar los pantalones que, por muy pequeños, no sirven a la tropa: diga Ud. que compren un poco del mismo género y se les pone un chazo en forma de vivo o tira. (Lecuna, 1947, Tomo II, p.599)

Mediante su secretario Revenga dispone el 25 de abril de 1827 que las mercancías de exportación o consumo cancelen una sola vez dicho impuesto, y no tantas veces se vendan o permuten, según manda su anterior decreto de fecha 9 de marzo. Dicha norma se 
atenúa "teniendo S.E. en consideración los perjuicios que se seguirían a la agricultura del recargo que de este modo tendría el precio de dichos efectos" (Blanco y Azpúrua, 1978,Tomo XI, pp.249-250).

Bolívar resume completa anarquía que ha causado la asignación de las deudas militares, a través de la memoria que su secretario José Rafael Revenga presenta al ministro de Hacienda el 23 de mayo de 1827:

"El desorden que en ella indico se extendía como era natural a la concesión y pago de los haberes militares. Se han dado íntegros a personas que dejaron de existir desde antes que empezara la época asignada; pero esto ha sorprendido menos al Libertador que ver que se hayan concedido a personas que nunca han militado o que sólo como caminantes o por custodiar sus propiedades se han ceñido alguna vez la espada. No se tienen todavía los estados de haberes declarados que ya se han pedido a todas las comisiones; más espanta la crecida cuantía de lo que después de repartidos todos los bienes nacionales que había en los llanos se ha tomado prestado a virtud de la Ley de 23 de julio del año $13^{\circ}$ para satisfacer haberes; y espanta aún más el número de reclamos que a pesar de ello existe todavía. Estime Ud. de aquí, cuántos no se habrán dado indebidamente; $y$ añada Ud. a esta culpable libertad la falta de diligencia en cuidar de las propiedades confiscadas o sólo secuestradas, y las que ha habido en secuestrar y aún en descubrir las que la ley condena. De aquí es que casi no hay ya un depositario que quiera conformarse con la propiedad que se le había designado para el pago por el precio que tuvo al recibirla; de aquí es que con tanta frecuencia se insta por cambiar unas propiedades por otras; de aquí es también que para averiguar ocultaciones se ha mandado formar lista de todas las propiedades que pertenecían al enemigo o a los que con él emigraron o que estos poseían. (Blanco y Azpúrua, 1978, Tomo XI, p.285)

Sobre el conjunto de medidas para disminuir los gastos militares y ordenar la intendencia castrense, en la extensa comunicación del 23 de mayo de 1827 Bolívar resume al ministro de Hacienda por conducto de su secretario José Rafael Revenga:

Los otros de 16 y 19 de enero reduciendo el sueldo a los militares; el de 13 de febrero incorporando en uno los anteriores departamentos primero y segundo de marina; y el de 16 suprimiendo la Corte Superior de Justicia de Maturín están sobradamente fundados en la economía que los ha hecho necesarios. El del 22 del mismo febrero que arreglaba los bagajes no solo tiene aquel fundamento sino también la conveniencia de cortar los abusos que sobre ellos se habían introducido en perjuicio de la agricultura y del erario y con vejamen de los pueblos, pedíanse o tomábanse por la fuerza aun para pasearse los domingos: pedíanse o tomábanse por la fuerza aun para enviar sirvientes a algunas comisiones, y para los que no eran militares; $y$ raras veces se devolvían a sus dueños, si estos no enviaban a buscarlos. (Blanco y Azpúrua, 1978, Tomo XI, p.284)

Sobre el estado en que el Libertador encuentra la cosa pública de Venezuela en su visita, resume su secretario José Rafael Revenga en comunicación dirigida al ministro de Hacienda el 23 de mayo de 1827:

La hacienda de estos departamentos no existía para la República; se cobraban real o aparentemente todas las contribuciones, pero desaparecían aún antes de cobradas. Se debe muy poco de las directas; pero rarísimo ha sido el recolector que ha rendido cuentas, ni que haya publicado lo que cada uno debía, o lo que había recaudado. Las 
aduanas litorales no producían ya casi nada para el Estado. La renta de tabaco cuyos productos llegaron antes en estas provincias a más de un millón y doscientos mil pesos apenas producía ahora la cuarta parte. En los lugares donde se llevó a efecto el arrendamiento de las salinas las dejaron gravadas arbitrariamente para lo futuro. La Ley de Patentes se había publicado pero no se había dado un paso más allá. No lo estaba la de hipotecas y registros; no lo estaba sino parcialmente la de auxilio al crédito público, ni la que arregla el papel sellado. Vendíase éste conforme a la ley anterior; pero había quienes casi públicamente lo vendiesen a menos precio. No había en realidad tribunal de cuentas; de modo que la administración de hacienda no era a la verdad sino una sombra tras de la cual estaban ocultas la indiferencia hacia el bien común, la desaplicación al trabajo y las más de las veces muchas más graves faltas. (Blanco y Azpúrua, 1978, Tomo XI, p.285)

Sobre el deplorable estado en que encuentra el Libertador la administración del estanco del tabaco, dirige Revenga el 23 de mayo de 1827 extensa memoria al ministro de Hacienda:

Todas las oficinas tenían sus trabajos atrasados y algunas por muchos años lo único de que se cuidaba en las principales era de formar estados mensuales que ni contenían lo que debían, ni de ningún modo prueban seguridad, acierto, ni rectitud, sino en la correspondencia de las partidas que se asentaban. No se corregían los errores ni las comisiones de las colecturías subalternas; estimábase por bueno cualquier comprobante; tratábase el negociado como propiedad de los que lo manejaban; en unas partes no producía la renta del tabaco lo necesario para su sostén, y en otras se consumió en sueldos lo que estaba destinado a fomentar las plantaciones: el contrabando de tabaco se hacía hasta por partidas de 40 y 50 cargas; en algunas provincias no había un solo estanquillo, y en otras de viejo se podría el tabaco. Convertidas en lonjas de comercio algunas oficinas, era tan notorio el vergonzoso tráfico que en ellas se hacía de las órdenes y pagos, que no entraban a ellas ningún acreedor sino sobrecogido de la deducción que se le propondría para conseguir el reintegro del resto; los libros están llenos de órdenes o vales endosados a favor de los guardianes de las rentas, negociados por ellos y pagados de preferencia a todo lo demás. Ha habido tesorería provincial a la cual se suponía que una señora hiciese suplementos mensuales por ocho o diez mil pesos en efectivo y por los cuales se libraba sobre otras; las ha habido donde dejaban de pagarse los sueldos si el asalariado no consentía en recibirlos en mercancías y esas al precio que les ponía el vendedor; no era raro ver a un administrador enviar al juego partidas de treinta o cuarenta onzas de oro, algunos de ellos se han retirado opulentos al cabo de pocos meses; $y$ aun ha habido subalternos que habiendo entrado a servir destituidos de lo necesario, han adquirido dentro de un año más de 50.000 pesos de caudal. (Blanco y Azpúrua, I 978, Tomo XI, p.286)

El 7 de agosto de 1827 el Congreso expide la Ley por medio de la cual se convocaba a una gran Convención Nacional para el 2 de marzo de 1828 en la ciudad de Ocaña, donde se intensificarán aún más estas discrepancias. Bolívar regresó a Bogotá a principios de 1828, encontrando una fuerte resistencia en los medios políticos que se agrupaban alrededor del general Santander. La confianza que el Libertador depositaba en sus más cercanos colaboradores militares, en su mayoría venezolanos e ingleses y los más frecuentes excesos de estos, agregaron un motivo más para las divergencias existentes entre Bolívar y los miembros del Congreso.

Ya con el Decreto del 14 de marzo de 1828, Bolívar había resta- 
blecido el monopolio de los aguardientes y el impuesto a la destilación. La Convención de Ocaña fue instalada el 9 de abril de 1828. Se produjo el inevitable enfrentamiento entre bolivarianos y santanderistas. Estos últimos, a la sazón federalistas, lograron una gran representación en tanto que los bolivarianos decidieron abandonar las deliberaciones por lo cual no se logró el quorum. Tres meses después la Convención fue clausurada sin resultados.

El 28 de julio dicta el decreto para la media anata y la anualidad $y$, decidió finalmente, en 27 de agosto de 1828, declarar la dictadura tratando febrilmente, durante unos meses, reconstruir la autoridad que se desmoronaba. Eliminó el cargo de Vicepresidente, desempeñado por Santander quien renunció el 7 de septiembre y dictó decretos de emergencia económica.

En tal atmósfera de tensión, los jóvenes liberales, en un ambiente que les hacía evocar el paso de la Roma republicana a la monarquía del César, decidieron atentar contra el "tirano" y en 25 de septiembre de 1828 intentaron matar a Bolívar. Como epílogo de la conspiración septembrina, fueron sentenciados a muerte catorce conjurados y, Santander, a quien se atribuyó la autoría intelectual también fue condenado a muerte pero se le conmutó la pena por el destierro.

Con el Decreto II 5 de octubre de 1828 restablece el tributo indígena después de muchas consultas con la justificación de que colocaba a la población indígena en inferioridad tributaria (Restrepo, 2010, p. 79). Eliminó de la educación la enseñanza de Bentham y disolvió las organizaciones masónicas con el ánimo de apaciguar a la beligerante oposición de los adeptos católicos.
Gran parte de su extenso informe La Hacienda Pública de Venezuela I828-I 830 está lleno de patéticas relaciones sobre la situación económica del momento,y de informes sobre el accidentado avance del proyecto relativo al tabaco. Uno de los resúmenes más competentes de este consta en la comunicación que dirige Revenga el 6 de abril de 1829 al señor Intendente de Venezuela, director de Rentas:

Crece diariamente el descrédito de Colombia por la falta de pago del rédito y amortización de la deuda que ha contraído fuera del pais; $y$ no bastando las rentas ordinarias para satisfacer a esta obligación, y aun cuando bastasen, careciendo nosotros de numerario con que poder trasladar progresivamente a Europa cuantiosos valores, y hallándose tan abatido allá el precio de los frutos coloniales, ha cifrado el Libertador en la Renta del Tabaco todas sus esperanzas de cumplir con este empeño nacional. Sólo ella puede dar a los ingresos ordinarios el aumento de que necesitan; $y$ hacer crecer o al menos conservar trasladados a Europa los valores que aquí haya disponibles. (Revenga, 1984, p.66)

Bolívar encomienda a su secretario Revenga la realización del proyecto, $y$ este lo asume con energía y diligencia.

La República tiene que pagar anualmente en Londres cuatrocientas setenta y dos mil y quinientas libras esterlinas, fuera de todo lo caído desde enero de 1826, y de fletes, comisiones y demás gastos. Para satisfacer esta suma con el producido del tabaco que se exporte, necesita remitir mucho más de sesenta mil quintales. No ha de esperarse que encuentre pronto y conveniente mercado tamaña cantidad, mucho menos si toda ella es de la misma clase. Pero careciéndose de otros medios de aumentar los valores, $y$ de efectuar las remesas, he tomado ya los conducentes a descubrir todos los mercados que puedan convenir, tanto al cura seca de Barinas, como a otros que se asemejan al de Cuba (Revenga, 1984, p.66).

Samuel Leónidas Pérez Grau 
Perseverante, ya el 14 de abril de 1829 se dirige Revenga al secretario de Rentas, J. Castillo y Rada, insistiendo sobre la dedicación de la renta del tabaco al pago de la deuda:

Se propone el Libertador fomentar las plantaciones de tabacos, y a este fin dispuso desde enero último que no se extrajese nada de sus cajas: y esta renta se fomentará vigorosamente. Se llevará a efecto la ley de registros e hipotecas, $y$ unido al producto de todas ellas a los ahorros que permita la severa economía a que se propende, y a los mayores productos que deben esperarse simplificada la administración, mejor dotados los empleados, y fiscalizados más de cerca y más eficazmente; contará la República con qué hacer frente a su deuda extranjera, o deberá declararse incapaz de pagarla. (Blanco y Azpúrua, 1978, Tomo XI, p.223)

El 19 de mayo de 1829 escribe Revenga al Consejo de Ministros: He tomado diversas medidas para popularizarlo en la Gran Bretaña y estimo el suceso de suma importancia, porque desde que se consiga, no solo contarse con que se consuman allí grandes cantidades, sino con establecer en Londres el gran mercado de tabaco de Barinas.

Sin embargo, en el momento en que se está por embarcar el primer gran cargamento desde Angostura, una orden del presidente José Antonio Páez lo impide y ordena "que se pusiese a la disposición de la Dirección de Rentas y que se subastase dentro de ocho días". El intempestivo remate favorece a la firma inglesa Ackers y Huizi que adquiere el tabaco a bajo precio y puede revenderlo con gran ventaja en el extranjero. El proyecto se confunde con una de las últimas esperanzas de Bolívar, y constituirá también uno de sus postreros desengaños (Brito, 1966. p.383).

Entre tanto, en Colombia la dictadura de Bolívar no podía consoli- dar la unión entre Venezuela, Ecuador y Colombia, ni tampoco mantener el orden. Durante los días 23 y 25 de noviembre de 1829 tuvieron lugar unas asambleas populares en las ciudades de Valencia y Caracas que acordaron la separación definitiva de Venezuela del gobierno de Bogotá y el desconocimiento de la autoridad de Bolívar. En el otoño de 1829 se sublevó Antioquia. Solamente hubo un pequeño respiro en la noticia de que el ejército peruano había sido vencido finalmente en 1829.

El primero de febrero de 1830 desde Bogotá promulga el decreto en el cual ordena que se admitan los títulos de la deuda consolidada como pago de porciones de cuatro millones de fanegadas de tierras baldías que la Nación saca a la venta, fundado en los siguientes considerandos:

$1^{\circ}$ Que estos cuatro millones de fanegadas $(2.560 .000 \mathrm{Ha}$.) fueron puestas por el legislativo a disposición del ejecutivo para fomentar la inmigración extranjera, lo que hasta el momento no se ha podido realizar pese a las contratas y concesiones hechas;

$2^{\circ}$ Que siendo los extranjeros en gran parte los tenedores de los vales colombianos, si adquiriesen propiedades en territorio de la República vendrían a ser también más interesados en su prosperidad y mejores ciudadanos, $y$

$3^{\circ}$ En fin, que el gobierno desea satisfacer a todos sus créditos con provecho de la República aunque por lo inmenso de la deuda que hoy pesa sobre ella es imposible por el momento cubrirla religiosamente con sus intereses como desde luego quisiera hacerlo (Barnola et al., 1964, Tomo III, pp.383-384)

Esta política de intentar cancelar la deuda y atraer la inmigración europea dando en pago tierras baldías tampoco tendrá éxito. Como señala Vladimir Acosta: 
Esta fue la orientación fundamental por lo menos hasta 1873. Sus resultados fueron casi nulos, y sólo lograron poner a veces en peligro el futuro del país. Las leyes aprobadas desde 1823 hasta mediados de siglo, insisten en esa venta o arrendamiento de baldíos para amortizar la deuda externa, tratando de interesar en la compra a los tenedores extranjeros de bonos de la misma, casi todos ingleses, pero sin ningún resultado tangible. Los intentos de colonización comienzan con las leyes de 1823 y de 1826 que destinan respectivamente tres millones ( $1.920 .000 \mathrm{Ha}$.) y un millón de fanegadas $(640.000 \mathrm{Ha}$.) al fomento de la inmigración, preferiblemente de agricultores y artesanos, y por supuesto europeos, es decir, blancos. (Acosta, 1983, p.56)

Él mismo está tan cargado de acreencias como las repúblicas que ha creado ambos patrimonios, el personal y el público, se han agotado en el tremendo esfuerzo emancipador. Quizá la conciencia de la terrible situación es lo que lo fuerza a exclamar, en su mensaje de despedida ante el Congreso constituyente: “¡Conciudadanos! Me ruborizo al decirlo: la independencia es el único bien que hemos adquirido a costa de los demás”. Mas en el fondo de esta caja de Pandora queda la esperanza, y cierra Bolívar su carrera política invocándola: "Pero ella nos abre la puerta para reconquistarlos bajo vuestros soberanos auspicios, con todo el esplendor de la gloria y de la libertad" (Lecuna, 1947, Tomo III, p.8I7).

El 20 de marzo de 1830 convocó a una asamblea constituyente con el fin de conciliar las diferencias que se crearon y evitar la disolución. Esta asamblea fue llamada el Congreso Admirable porque a pesar de la asistencia de personas de diferentes ideologías no logró concretar la unión de las regiones en torno al mundo de Bogotá. Frustrado y enfermo, Bolívar decidió abandonar el poder en 4 de mayo de 1830 quedando entonces Domingo Caicedo como Presidente interino.
El 6 de mayo de 1830 se instaló en Valencia el Congreso Constituyente que confirmó a José Antonio Páez como Presidente de Venezuela. Es cuando Bolívar sale de Bogotá en 8 de mayo, hasta su destino en Santa Marta, donde murió a los pocos meses. El 13 de mayo de 1830, el Distrito del Sur declaró la independencia de Colombia, conformándose la República del Ecuador de donde surgió Juan José Flórez, natural de Venezuela, como Jefe Supremo del Gobierno ecuatoriano. El descontento militar y la pugna de los grupos liberales desembocó en la dictadura del general Rafael Urdaneta, hasta que una fuerte coalición de dirigentes granadinos lo obligó a renunciar y nuevamente asumió el poder Domingo Caicedo.

Con la llamada Junta de Apulo que tiene lugar el 28 de abril de I83 I se reestablece el gobierno legítimo del vicepresidente Caicedo. Ahora solo restaba protocolizar la disolución de la Gran Colombia y para este efecto fue convocada la Convención Granadina de I83I, la cual acepta la renuncia del vicepresidente Caicedo a partir del I5 de octubre de 1831 y estando el presidente titular (doctor Joaquín Mosquera) fuera del país eligió al general Obando como Presidente y al doctor José Ignacio de Márquez como Vicepresidente. En 1832 , el Congreso Admirable elige al general Santander como Presidente de la Nueva Granada y al doctor Márquez como Vicepresidente.

Como el general Santander se encontraba fuera del país, el doctor Márquez ejerció la presidencia de la Nueva Granada durante ocho meses, hasta el regreso del titular. En este sentido puede decirse que don José Ignacio de Márquez fue el primer presidente que ejerció las funciones presidenciales en Colombia, pues hasta 1832 los presidentes lo habían sido de la Gran Colombia. Entre las labores que adelantó el doctor Márquez resulta de nuestro interés resaltar la de 
haber sentado las bases de la contabilidad nacional y reorganizar la Hacienda Pública del país, de conformidad con las recomendaciones que él mismo había formulado como Ministro de Hacienda del general Caicedo ante el Congreso Admirable (Restrepo, 20 I0, p. I 40).

\section{Conclusiones}

\section{EL FRACASO DEL PROYECTO REPUBLICANO}

Son diversas coyunturas las que mantuvieron al proyecto republicano de la Gran Colombia en permanente crisis, de tal manera que si se bautiza al conjunto de estos factores coyunturales como "crisis interna grancolombiana" se configura una perspectiva estructural y holística.

Las principales coyunturas explicativas del fracaso republicano se resumen en las siguientes causales:

I. La Guerra de Independencia había arruinado al país; la producción y el comercio estuvieron semiparalizados durante el primer quinquenio.

2. Los caudillos regionales descontentos con la adopción del centralismo político, mantuvieron las pugnas políticas y las rivalidades regionales, contra la Constitución de Cúcuta, contra el Gobierno Central y contra la autoridad de los Gobernadores, durante toda la vida republicana.

3. El extenso y accidentado relieve del territorio de la República impedía el transporte y las comunicaciones ágiles.

4. El Presidente estuvo ausente casi la mitad del mandato, delegando en mentalidades separatistas la administración que obstaculizaron la consolidación republicana.

En términos de la calidad de las primeras decisiones políticas rela- 
cionadas con el mejoramiento de las condiciones sociales y económicas de la posguerra y de la necesidad de instaurar un orden fiscal mal podría decirse que los funcionarios no tuvieran la preparación gubernativa o los méritos para ocupar dichos cargos. Sin embargo, se hace necesario seguir profundizando en el tema para intentar el descubrimiento de los factores administrativos y estructurales que a la postre impidieron implementar apropiadamente estas reformas que prometían satisfacer plenamente las demandas de desarrollo que planteaba el nuevo país.

Entre las principales razones políticas que dieron al traste el proyecto republicano se suelen mencionar:

I. No lograron integrarse las unidades legislativa y ejecutiva en la concepción de una política contable que pudiera evitar la fragmentación del manejo económico y el control fiscal de la República.

2. No se generó la voluntad política requerida para acometer las reformas fiscales que la doctrina liberal reclamaba.

3. No inspiraron en la población y los funcionarios públicos la confianza en el equipo de gobierno, la pertenencia al proyecto de Nación en construcción, el compromiso patriótico de servirle para garantizar a las nuevas generaciones un país y una forma de vida digna.

La idea que ahora guía este estudio es poder establecer ¿Cuál fue el modelo de planificación y control contable aplicado por las autoridades administrativas del proyecto republicano la Gran Colombia? ¿Cómo eran los elementos del Control Interno en la Gran Colombia? ¿Cómo funcionaba la Auditoría Interna en la Gran Colombia? La aclaración textual de estos y otros interrogantes darán sentido a la intención de comprobar la capacidad del cuerpo directivo del turno republicano grancolombiano de entonces, para interpretar opiniones de auditoría o de control interno que pudiesen haber estado anunciando señales de estrés financiero $\circ$ anticipando alertas de fracaso institucional.

La Planificación del Desarrollo debe mirarse como una estrategia administrativa del Estado. La Planificación Contable del Desarrollo se refiere a una serie de marcos conceptuales, de procedimientos y operaciones del manejo contable que deben mirarse ligados a la Política de Estado. La función de la Contabilidad es garantizar que los responsables de "crear valor" lo hagan para que la riqueza cultural devengada sea más satisfactoria del interés general de la sociedad. La Planificación a la que está llamada la Contabilidad tiene que ir dirigida en el sentido de evaluar la manera en que los impactos que experimenta cotidianamente la Sociedad se constituyan en un horizonte no solamente del valor de cambio sino también de la productividad y su distribución.

La Contaduría Pública cumple una función social importante en el diseño de procesos de información, de control y de rendición de cuentas sobre la gestión del desarrollo; es además una práctica social de carácter público y debe velar por los asuntos concernientes a la comunidad, es decir, que la disciplina contable y el ejercicio profesional de los contadores deben estar en favor del beneficio social.

\section{Los hechos materia de información y control contable}

Un primer momento para la materialización de una Planificación Contable es hacer la identificación de los hechos que serán materia de información y control contable. Se requiere construir un plan 
macro de gestión nacional en el cual se tenga muy claro que es lo que se va a hacer en materia financiera, económica y social y que se defina qué es, lo que dentro de esa armonía, va a hacer la contabilidad. La Planificación Contable no se puede aislar de esas necesidades. Se requiere de su articulación,

en esa Planificación entran en juego la participación, las intenciones, la tecnología, las concepciones, entra también lo que se quiere en materia contable para la nación, en términos de desarrollo, no se puede seguir respondiendo a la coyuntura. (Quirós y Bustamante, 20II p.206)

Después de la Independencia, mientras España perdía el monopolio comercial con el que había sojuzgado a todas las colonias americanas, Gran Bretaña se convertía en el principal abastecedor de mercancías de importación, seguida en menor proporción por Francia, Alemania y Estados Unidos. representaba este último el más importante mercado de exportación de provisiones alimentarias (harina, carnes saladas, mantecas, etc.) y en menor proporción figuraban Francia, Gran Bretaña y Alemania (Bushnell, 1985, p.202).

La Nueva Granada tenía que ver sobre todo con los impuestos a los metales preciosos y en un principio solamente el oro amonedado podía ser sacado del país a una tasa del $3 \%$. La extracción presunta se aplicaba sobre todas aquellas importaciones que no eran directamente intercambiadas por exportaciones colombianas en cuyo caso se registraba una salida ilícita de oro el que entonces era gravado como si hubiese salido por las secciones de aduana. Una gran cantidad de las importaciones, hasta del $60 \%$ del comercio total de exportación como expresara en su informe Castillo y Rada (1827), llegaba a través de intermediarios de Kingston, Santo Tomás y de Panamá, como resultado del trueque de la extracción ilegal de metales preciosos, sin el pago del quinto o de los derechos de exportación (Bushnell, 1985, p.III).

No puede afirmarse que la generación fundadora de la Gran Colombia hubiera estado alineada ni con un proteccionismo a ultranza, ni con un librecambismo salvaje. Se adoptó un pragmático punto medio en el que el impuesto de aduana cumplía a la vez propósitos recaudatorios y fines de moderada protección para las industrias nacientes, sin cerrar el comercio de Colombia a los intercambios internacionales (Restrepo, 2010, p. 104).

En la pequeña producción agraria, la familia erigió básicamente su mano de obra, consumiendo parte de lo que producía e intercambiando el excedente por otros productos ya sea tanto para el consumo como para generar posibles ahorros. La actividad hacendal, aunque disminuida, se mantuvo como un ámbito de producción agrícola-ganadera muy cerrado, cimentado sobre relaciones de producción de esclavitud y de servidumbre. Los cultivos más frecuentes emprendidos bajo una óptica comercial tanto local como internacional, consistía en cultivos de algodón, caña de azúcar, añil y cacao, principalmente en los Santanderes, Antioquia, Caldas, Tolima y el altiplano cundiboyacense. Al mismo tiempo que sobreviviente, el sistema de producción hacendal seguía configurándose como un obstáculo para el desarrollo económico y social porque favorecía el interés de los propietarios en concentrar mayormente la propiedad y restringir la libre movilización de la mano de obra servil, la remunerada en dinero $y$ en especie, $y$ los esclavos (Jaramillo, Meisel, y Urrutia, 1977, p.32). 
Parte del sector propietario concebía la expansión exportadora como la única forma viable del desarrollo. Para estos, la función modernizadora del nacionalismo anticolonial se convirtió en una ideología que facilitaba la importación para un consumo de la élite y de las inversiones especulativas más que transformadoras. La otra parte de los propietarios buscaba en las formas de producciónespeculación la manera de reproducir sus capitales, siendo las actividades preferidas las haciendas, la compraventa de tierras, el comercio local, los valores de la deuda pública y el capital financiero. El inversionista especulador estaba dispuesto a establecerse donde encontrase posibilidades de obtener buenas ganancias. No tenía inconvenientes el empresario para emigrar a otros negocios sin importarle mucho la quiebra del negocio o las consecuencias para sus relacionados.

En la Colombia republicana no es que hubiera estado ausente la planificación, sino que fue inadecuada y reactiva, es decir, ciega... que se desarrolló sin una política contable que aportara una visión de cómo atender las necesidades informativas y de control de la nación en materia financiera, económica y social. La política contable como tal, nunca existió, lo que quiere decir que siempre se movió a través de improvisaciones y cuando no la hay no es posible construir conocimiento contable adaptado a las necesidades del país. (Machado Maro, Medellín, 20 de febrero de 2008, citado por Quirós y Bustamante, p. 188).

Para la época, la política y la administración formaban todo un ámbito monolítico. El tema de la administración no había sido planteado siquiera como una materia o disciplina de estudio. Lo que se decía y hacía se planteaba como alineación al liberalismo político o al realismo absolutista. El problema de lo contable de entonces en Colombia se ve agravado porque tampoco podía hablarse de la existencia de una comunidad contable, pues solamente habían "élites" $y$ desde estas apenas son unas cuantas personas las que investigan y se retroalimentan en sus mismas teorías, pero no se alimentan de otros nuevos campos de investigación.

La contabilidad pública nace en Colombia con el propósito de organizar la Hacienda Nacional de la República recién constituida, sumida en una ruinosa situación financiera. En el ámbito de la época republicana de la Gran Colombia el sistema contable que aparece con mayor frecuencia es el de cargo y data. Según reconoce Hernández Estévez (2007, p.223) no se ha encontrado un manual específico sobre este modelo y los documentos que se conocen mencionándolo son textos insertos en libros objetivos más amplios.

Al examinar la contabilidad desde una lógica del interés colectivo podemos descubrir que a ella corresponde ejercer la función social de control. El análisis contable consiste en visualizar las interacciones entre las lógicas sociales de la producción y la distribución, para poder evaluar la distribución del valor agregado sobre el equilibrio heredado y el que se le debe transmitir a las generaciones futuras. En tal sentido, es necesario que la contabilidad participe de propuestas de desarrollo social desde el interés público en un escenario ético donde quedan vinculados los procesos de rendición de cuentas y responsabilidad social de cada generación con las venideras. Realmente ello no estuvo previsto en las primeras reformas organizadoras de la Hacienda.

La cuenta de cargo representaba las cantidades que el funcionario había recibido para gastos de la empresa y estaba conformada por 
partidas o libros auxiliares que se complementaban como el libro de inventarios (expresan los activos fijos necesarios para la explotación) y la cuenta del producto de la empresa (expresan el costo de la producción). La cuenta de data indicaba las partidas que componían el descargo de lo recibido. Las tesorerías provinciales y las de administraciones de ingresos de ramos reciben cada mes visitas de control o "visitas de arca". Los depósitos de estas tesorerías se remiten a las tesorerías departamentales una vez se relacionan los descuentos por los sueldos de los funcionarios y los insumos $y$ gastos fijos de las oficinas.

La cuenta del administrador o director específico, conjugada con las contabilidades de partida simple en las que el control de la existencia física era lo importante como perspectiva de los derechos y obligaciones de la persona natural, se vinculaban con la producción y la contabilidad general a través de lo que le era entregado y recibido desde la tesorería general, requiriendo entonces el administrador dar cuenta y razón de cómo y en qué modo había sido consumido lo enviado por tesorería (jornales, víveres, materiales), lo que en los registros específicos venía a significar los consumos corrientes necesarios para lograr la producción de la empresa.

\section{Los objetivos y prioridades de información y control}

Un segundo momento consistirá en traducir esos inventarios de necesidades en objetivos y prioridades de información y control, entendidos como conjuntos de hechos o fenómenos sobre los que recaen las acciones técnicas de la gestión contable. Se puede definir el control como el conjunto de conceptos, acciones, instrumentos y procedimientos dirigidos a delimitar las actuaciones que afectan el interés público, lo cual en una perspectiva social demanda la teorización y aplicación de procesos socialmente compartidos.
El control social de la gestión del desarrollo solo puede hacerlo una sociedad informada, factor productivo necesario para mejorar el funcionamiento de los mercados, reducir las asimetrías y los costos de transacción, al tiempo que hace transparentes, participativos y eficientes los sistemas políticos y el funcionamiento de los gobiernos. Para hacer control social de la gestión del desarrollo se requiere de procesos de información que permitan rendir cuentas acerca de su cumplimiento, promoviendo la equidad social y la democracia.

Desde la Constitución de Cundinamarca de 1812, había estado presente la pretensión liberal de lograr una hegemonía ideológica a través de la importación de un modelo individualista o de liberalismo social encontrando la resistencia para ello de las castas existentes y la multiculturalidad característica neogranadina, lo que a la postre trajo consigo la mutación del liberalismo político desde sus tonos republicanistas a unos tonos monárquicos, y desde sus tonos económicos a unas movilidades entre castas y clases sociales, etc., mixturas estas que terminaron siendo nuestra forma de asimilar modelos foráneos.

En esa misma línea, desde el principio de la Constitución de I82I, los principios del liberalismo económico riñeron con los esquemas del liberalismo social no quedando más opción que la construcción, al mismo tiempo, de un Estado republicano que otorga una libertad restringida a las colectividades o grupos, destruye la unidad de clase social y se plantea una separación entre la vida pública y la vida privada, de modo que la primera se hace competencia exclusiva del Estado y la segunda de la Sociedad, con la de un Estado democrático, protector del menos favorecido, la propiedad del suelo colectivo y la prohibición del monopolio (Alarcón, 2013, p. 185). 
Por otra parte, el sistema de administración pública adoptado por la Constitución de 1821 marca el comienzo de una tensión entre los partidarios de un sistema de organización estatal unitaria centralizada, versus los partidarios de un sistema federal. Los centralistas afirmaban que Colombia no tenía "ni la ilustración ni las costumbres" necesarias para una federación. Los federalistas alegaban que los estados soberanos constituían una barrera contra la tiranía del Ejecutivo (Bushnell, 1985, p.33).

Se torna evidente la importancia que en la época y en el ámbito empresarial y de los negocios se le daba a la revisión de cuentas dadas las implicaciones pecuniarias y penales que conllevaba para los funcionarios y operarios violar los reglamentos; era tan crucial la revisión de cuentas que se efectuaba en tres niveles y tiempos: en el primero operaba el contador y el tesorero o administrador de todos los ramos de las rentas públicas del nivel provincial (tesorero y contador), en el segundo el contador $y$ el tesorero departamental (el contador y un propietario en el caso de lo privado), y en el tercero el Director General de Hacienda y probablemente el contador departamental (otro propietario y probablemente el contador).

La primera revisión en las oficinas y administraciones (empresas) diversas permite captar la importancia de la función tesorera, en la que el contador además de velar por el adecuado manejo del dinero oficia como revisor de las cuentas en las diversas oficinas $y$ administraciones. (en algunas empresas privadas pequeñas el tesorero además de ser responsable del adecuado manejo del dinero pudiera oficiar como contador sujeto a la rendición de cuentas ante el revisor de las cuentas en las diversas empresas de la compañía). El examen que el contador debe hacer de las cuentas del tesorero no se contraerá únicamente a las operaciones aritméticas, sino que también debe versar sobre lo formal y sustancial de las cuentas, considerar si los gastos hechos han sido o no corrientes y si están debidamente justificados debiendo deducir el alcance del responsable por los gastos indebidos, ya sea que se hayan hecho sin la autorización del caso, o contrariando las disposiciones del estatuto contable, o a que ello no esté debidamente comprobado. Efectuada la revisión el contador le comunicaba al tesorero, quién debía hacer los descargos o aceptar su responsabilidad, con lo que finiquitaba la primera revisión.

La segunda revisión se efectuaba por el contador departamental (un propietario designado para tal efecto) junto al contador, y recaía sobre todas las cuentas del primer finiquito, más los registros e informes efectuados por el Tesorero. En esta segunda revisión el contador departamental desempeñaba la parte esencial de una evaluación general sobre el manejo de la producción y registro de la misma. Esa evaluación básicamente tenía significación ante la Dirección General (al interior de la compañía) e indirectamente pudiera requerir apelaciones sobre los hallazgos, incidir para soportar sanciones luego de los descargos por anomalías o reclamos de la Dirección (la compañía) en los juicios y pleitos contra los involucrados en irregularidades.

Una tercera revisión podría ser solicitada por algún afectado y el contador tendría la obligación de glosar las cuentas. El Director General (consejo directivo) podría trasladar la solicitud a uno de los contadores departamentales (consejeros), no pudiendo recaer en quien la examinó anteriormente. Este tipo de dictamen no tenía apelación ante la Dirección General (al interior de la empresa). 
El proceso de liquidación o finiquito de cuentas se componía de cuatro fases:

a. Examen de justificantes de las operaciones,

b. Verificación de las cifras,

c. Pagos en efectivo,

d. Liquidación de la cuenta.

Si la primera y segunda fases no requirieren mayor explicación, en la tercera (prevenciones de alcances y faltantes en la caja) y la cuarta (redacción del informe de finiquito) se centra la sustancia del procedimiento, como lo es en el Derecho de Obligaciones donde el presentador de la cuenta es deudor del saldo, una deuda que resulta de su gestión, o acreedor del excedente de los cobros sobre los pagos. En síntesis: quien recibe, debe (Villaluenga, 2013, p. I28).

Al estar tan intervenido este modelo contable por el enfoque dominante, predominantemente liberal, la relación entre contabilidad y productividad no es clara pues el análisis contable se ha limitado a sus componentes financieros $y$ a las variaciones patrimoniales subsumidas en el capital, dejando de lado el análisis de los demás factores generadores de riquezas. Esta reducción de la contabilidad a unos informes financieros de la Tesorería General y de las Otras tesorerías de los ramos de la organización limita los procesos de $\mathrm{Pla}-$ nificación Contable a la búsqueda de soluciones tecnológicas limitadas a la organización, vista esta aisladamente, en su individualidad.

Desde siempre se ha sabido que la Contabilidad es la principal herramienta para el control de la información puesto que esta podría diseñar y proponer herramientas contables que de una $u$ otra manera ayuden a la gestión pública: los contadores públicos de todos los tiempos tienen la posibilidad de contribuir a aumentar la calidad de los sistemas de información para una adecuada toma de decisiones y así ayudar al mejoramiento de la información para el desarrollo social del país. En este sentido, en esos tiempos se requería con urgencia haber modificado sustancialmente la estructura de tal modelo contable que se fundamentaba en un concepto de mantenimiento del capital financiero, donde lo fundamental era el exceso o diferencia ente el patrimonio contable al final del período respecto al del comienzo, es decir, que las variaciones del patrimonio contenían resultados que no habían sido solamente fruto de la gestión de sus administradores $y$, más bien, migrar hacia concepciones más socioeconómicas que buscasen preferentemente un mantenimiento del capital operativo, consistente en contabilizaciones basadas en medidas de desempeño convergentes con el excedente de recursos o fondos que requieren la capacidad productiva física al final del período respecto al del comienzo, en razón a las características propias de la República con bajas posibilidades de desarrolllar un mercado especulativo de capitales y una infinidad de sectores primarios sin condiciones de financiarse para emerger al escenario de la competitividad.

En todos los tiempos, la identificación de necesidades, objetivos y prioridades de información y control está determinada por requerimientos prospectivos propios del desarrollo, así como por el seguimiento y fijación de metas fundamentales en el conocimiento de la productividad y también, el conocimiento, o a veces las indicaciones de los estudios existentes, sobre las interrelaciones de unidades de producción e intersectoriales en la determinación de costos económicos y sociales y de las variaciones de precios como política monetaria. 
La prospectiva propia de los funcionarios bien preparados o de las élites bien educadas, siempre estará presente en la delimitación de las condiciones estratégicas de la región o territorio a planificar (de inversión pública y privada, de cualificación de las fuerzas productivas y sociales en general, de aspectos de fomento empresarial de desarrollo económico, etc.) y, por ello, siempre resultaba posible marcar tendencias acerca de cuáles pueden ser los modelos contables más apropiados para sistematizar, informar y controlar la situación económica y social de una región o territorio concreto. Se llama contabilidad de la productividad a aquella práctica contable capaz de relacionar el problema de la eficiencia del capital en la producción con la eficacia en la distribución de los excedentes, lo que va más allá de la rentabilidad como centro del análisis de los modelos del mantenimiento financiero.

La Productividad se convierte entonces en categoría social atravesada por un componente económico y un componente político. Una Planificación Contable orientada desde la visión social de la productividad permite un análisis más profundo de ambos aspectos que la constituyen poniendo en contexto las mediciones que hacen de la productividad generada y la productividad distribuida, posibilitando un análisis del excedente de la productividad global de los factores. Es la revisión y enriquecimiento de categorías propias de los ámbitos de la Economía Política, de la Productividad, de la Prospectiva, del Desarrollo socioeconómico regional y/o nacional y de la misma contabilidad lo que configura un círculo virtuoso que permite reflexionar y repensar el papel de la contabilidad en la sociedad y que encuentra su punto de síntesis en la Planificación Contable.

Es la falta de dinámicas organizacionales de información y control lo que dificulta el desarrollo de los países, especialmente de los más vulnerables o "pobres" y no permite que estén informados para acceder, tomar decisiones, promover la participación y hacer control social de la riqueza. Idealmente, lo público debería visualizarse como la reivindicación de la dignidad colectiva que se materializa en políticas públicas acordes con los procesos de desarrollo humano dentro del territorio.

Por eso se ha dicho que la planificación es un proceso de resistencia que va en contravía de los intereses liberales que ignoran tanto las necesidades locales como la necesidad de articular las variables propias que pudieran generar alternativas de desarrollo con la dinámica internacional. Está visto que la articulación con lo global no es necesariamente un obstáculo para lo endógeno sino que quienes desean participar exitosamente deben partir desde el conocimiento de las necesidades de lo local y lo regional para poder confrontar las fortalezas de lo nacional con lo internacional. Es un camino en el que la planificación contable tiene mucho que decir, pero en el que va a encontrar muchísima resistencia porque hay una serie de grandes intereses aunados al poder político que prefieren el modo actual en el que están viviendo (Quirós y Bustamante, 20I I, p. 174).

\section{La regulación contable}

Por último, la Regulación Contable puede ser un instrumento poderoso para coadyuvar a la Planificación Contable del desarrollo económico y social, pero para ello requiere la unificación de reguladores y el respeto a los requerimientos regulativos nacionales conforme a la Constitución Política y demás legislación que contiene el reconocimiento de los derechos sociales y económicos de la población y aplicación de los procesos requeridos para su materialización.

Está visto que la corrupción también tiene lugar por fallas en los 
mecanismos de regulación social. Cuando un funcionario no está bien controlado por la institución, se corrompe fácilmente, porque tiene el camino libre para obtener un montón de beneficios con la tranquilidad de saberse impune. Los funcionarios corruptos, una vez que se afirman en sus cargos, harán lo posible por eliminar todos los controles que puedan poner límites a su acción.

La corrección de todos los males que condujeron a la Gran Colombia al fracaso solamente hubiese sido posible a partir de una Política Contable articulada desde los escenarios de decisión que permitiera la identificación de necesidades, intereses y actores que les correspondía intervenir en las agendas del desarrollo económico y social. Se trataba de asumir el compromiso de la institucionalización de la Planificación Contable, de tal manera que se hubieran podido construir sistemas de información, de control y de rendición de cuentas sobre los procesos de planificación del desarrollo económico y social de las regiones y de la misma Nación.

Esta nueva perspectiva requería, además del interés y del trabajo investigativo de los contables, de una voluntad política expresada en la formulación de política contable como una política pública, considerando que esta función estatal adquiere un carácter vinculante y contribuye a que el proceso de institucionalización se lleve a cabo en un menor tiempo.

En conclusión, es la política contable lo que permite definir qué se requiere hacer en materia contable para respaldar y lograr esa armonía, ese desarrollo económico y social, financiero, administrativo y político. La política contable representa el poder de decisión de una Nación con respecto a lo que quiere hacer con el conocimiento contable. Requiere preguntarle a la nación, a los diferentes agentes que participan en ella, qué es lo que se quiere en materia contable y obviamente esa pregunta puede ser resuelta cuando las autoridades encargadas de administrar la Nación hayan resuelto qué es lo que se quiere como Nación en materia financiera, económica, administrativa, social y política. La política contable es lo que nunca formularon los responsable de la administración de la Gran Colombia.

Desde estas ideas, la política contable requiere estar articulada a la política de Estado en materia de Desarrollo Económico y Social, que reconoce la existencia de múltiples intereses conflictivos que deben ser negociados y resueltos en un marco democrático. Este concepto permite pensar lo contable de forma articulada con los procesos sociales y económicos del desarrollo y por ello se habla aquí de política pública en materia contable, queriendo con esto decir que la contabilidad puede ser objeto de política pública y además ser un instrumento de información y control de la política pública en los diversos ámbitos en que ella opera, no solo en el de las organizaciones estatales como tradicionalmente se menciona. Para poderlo materializar, se hace necesario redimensionar los procesos de regulación contable de modo que la regulación no se limite solo a aspectos financieros que le han sido tradicionales, sino que oriente el cumplimiento de planes y estructuras del desarrollo nacional (Quirós y Bustamante, 20II, p. 178).

Es en el contexto internacional donde debe tomar más relevancia el fortalecimiento de las políticas nacionales para poder participar con relativas posibilidades de éxito en los procesos globalizadores, desarrollando primero capacidades y potencialidades hacia adentro. Comercio Internacional, Nación, Política Contable, Desarrollo Económico y Social, se van intersectando, ayudando a definir poco a poco el campo de la Planificación Contable. 


\section{Referencias Bibliográficas}

Acosta Saignet M. (1983). Acción y utopía del hombre de las dificultades. Caracas: Ediciones de la Universidad Central de Venezuela.

Alarcón Bernal, E. (2013). Las primeras constituciones democráticas en Colombia (I810-18/5). Bogotá: Universidad Nacional, Facultad de Derecho Ciencias Políticas y Sociales.

Ariza Buenaventura, E. D. (200I). El carácter de la empresa y la contabilidad en la Nueva Granada 1810-1890. Bogotá: Universidad Nacional, Sociología. Tesis.

Areválo, D. y Rodríguez, O. (200I). Gremios, reformas tributarias y administración de impuestos en Colombia. Bogotá: Universidad Externado de Colombia, p.447.

Barnola, P. P., Brice, Á. F., Briceño Peroso, M. Escalona Escalona, J.A., Iribarren Celis, L. Grases, P. Mendoza, C. Pérez Vila M. Pinto, M. (Comps), (1964). Escritos del Libertador, XIV tomos, Caracas: Sociedad Bolivariana de Venezuela.

Barret de Nazarís, E. Grases P., Pardo R., Pérez Vila, M., Pinto, M. (Comps). ( 196I). Decretos del Libertador, III tomos. Caracas: Sociedad Bolivariana de Venezuela.

Barriga del Diestro, F. (2010). Las finanzas en nuestra segunda independencia. Bogotá: Academia Colombiana de Historia.

Blanco, J. F.y Aspurúa, R. (1978). Documentos para la historia del Libertador, $X V$ tomos. Caracas: Ediciones de la Presidencia de la República de Venezuela.

Brito Figueroa, F. (1966). Historia económica y social de Venezuela. Caracas: Ediciones de la Universidad Central de Venezuela.

Bushnell, D. (1985). El régimen de Santander en la Gran Colombia. $3^{\mathrm{a}}$. 


\section{Ed. Bogotá: El Áncora Editores.}

Camacho Roldán S. (1976). Escritos Históricos y Políticos. Bogotá: Biblioteca Básica Colombiana. Citado por Restrepo.

Del Castillo y Rada (1826). Exposición del Secretario de Hacienda presentada ante el Congreso de 1826. Bogotá:Archivo General de la Nación.

Del Castillo y Rada (1827). Exposición del Secretario de Hacienda presentada ante el Congreso de 1827. Bogotá:Archivo General de la Nación.

García, M.V.y García Pérez, D. (2000). Decisiones financieras y fracaso empresarial. Madrid: Asociación Española de Contabilidad y Administración de Empresas (AECA).

Hernández Esteve, E. (2007). La contabilidad por cargo y data siglos XVI y XVII. Barcelona: Escuela universitaria de estudios empresariales.

Jaramillo U., Meisel A. y Urrutia M. (1997). Continuities and Discontinuties in the fiscal and monetary Institutions of New Granada 1783-1850. Borradores de Economía 74 CGN (1988) Contabilidad de la Nación: situación y reforma necesaria. Bogotá: Revista Económica Colombiana, Contraloria General de la Nación. Enero-Febrero.

Kalmanovitz, S. y López E. (2006). El PIB de la Nueva Granada en 1800: auge colonial, estancamiento repúblicano. Revista de Economía Institucional, 8(15), I6I-I83.

Lecuna,V. (comp.) (1947). Simón Bolivar Obras Completas, III tomos. La Habana: Ed. Lex.

López Garavito, L. F. (1992). Historia de la Hacienda y el Tesoro en Colombia I82 I-1900. Bogotá: Banco de la República.

Lynch, J. (2006). Simón Bolivar. Barcelona: Crítica.

Márquez, M. Franco, L. F. y Murillo, L. E. (2013). Los grandes hechos que hicieron una gran historia: Disolución de la Gran Colombia. Universidad de Celaya, Guanajuato. Consultado en: https://issuu. com/marthaavila6/docs/los_grandes_hechos_que_hicieron_una

Martínez Garnica, A. (2008). Colección Bicentenario: La agenda de Colombia 1819-1831. Bucaramanga: Universidad Industrial de Santander.

Mina, M. (1975). Esclavitud y libertad en el valle del Río Cauca. Bogotá: Publicaciones la Rosca.

Ocampo, J. A. (1984). Colombia y la economía mundial (I830-1910). Bogotá: Siglo XIX.

Ospina Vásquez, L. (1955). Industria y Protección en Colombia I8I01830. Medellín: Ed. ESF.

Pérez Herrero, P. (20 I I). Fiscalidad y política en Colombia (I82 I-I 830). Cádiz: XVI Congreso Internacional de Asociación de Historiadores Latinoamericanos Europeos (AHILA).

Pérez Vila, M. (Comp.) (1959). Cartas del Libertador, XII Tomos. Caracas: Fundación John Boulton.

Pinto Bernal, J.J. (2010). Finanzas públicas de Bogotá 1819-1830, Rev. UNal Bogotá:Anuario Colombiano de Historia Social y de la Cultura, 37(2), 87-109.

Pinto Bernal, J. J. (20I2). Las finanzas de la Gran Colombia. Alcalá: Instituto de Estudios Latinoamericanos.

Pinto Bernal, J. J. (20I3). Los orígenes del impuesto directo y progresivo en América Latina. Rev. UNal Medellín: Historia y Sociedad, 24(I), 53-77.

Purroy Turrillas, C. ( 1986). Los diezmos en Indias en el siglo XVIII. Santiago: Universidad de Chile. Derecho canónigo e instituciones. p. $16 \mathrm{I}$. Consultado en 30 de mayo de 2016. En: http://www.historiadelderecho.uchile.cl/index.php/RCHD/article/viewFile/24952/26303

Quirós Lizarazo, E. y Bustamante García, H. (20I I). Elementos de planificación contable. Medellín: UNAULA. pp.287.

Restrepo, J. C. (20I0). La hacienda pública en la Constitución de Cúcuta 
de 182I. Bogotá: Pontificia Universidad Javeriana, Facultad de Ciencias Jurídicas, Colección Monografías, 8.

Restrepo,V. (1952). Estudio sobre las minas de oro y plata de Colombia. Bogotá: Banco de la República.

Anexos

Revenga, J. R. (1984). La hacienda pública de Venezuela I828-I830. Caracas:Academia Nacional de la Historia.

Suárez Pineda, J. A. (2010). El campo contable en el proceso de la independencia de Colombia (1780-1830). Manizales: Universidad de Caldas, Rev. Lúmina I I ( I), 194-24I.

Tovar Pinzón, H. (1987). Los cambios en el terreno fiscal en la República. Bogotá: Revista Credencial.

Villaluenga de Gracia, S. (2013). La partida doble y el cargo y data como instrumentos de un sistema de información. Revista española de contabilidad, 16(2), I26-135.

Villaveces Niño, J. (2007). Formación de la deuda pública en Colombia (|82|-|873). Bogotá: Universidad del Rosario. Economía, Borradores de Investigación 84.

\section{ANEXO I: ELTRANSCURSO HISTÓRICO}

Ya desde la célebre Carta de Jamaica, dada en Kingston en 6 de septiembre de 1815, había entrevisto el Libertador Simón Bolívar la unión de Nueva Granada y Venezuela. Después de la Reconquista española ejercida por Morillo hasta mediados de 1816, solamente la provincia de Casanare había permanecido independiente. Las guerriIlas Ilaneras ganadas por José Antonio Páez fueron reforzadas por la llegada de refugiados, entre ellos el talentoso organizador granadino Francisco de Paula Santander y luego, procedente de las Antillas, el líder natural de la causa patriota, Simón Bolívar. No podía demorarse más la estructuración del Estado de este proyecto republicano, porque era necesario usar del crédito para poder obtener todo lo indispensable para la guerra. Casanare bajo el mando de Santander, había aceptado la subordinación al gobierno provisional venezolano, establecido por Bolívar en el Congreso de Angostura (Bushnell, 1985, p. 27).

Durante el breve lapso del "restablecimiento del Gobierno liberal de la Primera República", esto es entre el II de agosto y el 3 de octubre de 1819, las tareas del Poder Ejecutivo fueron diseñadas por consenso entre el Libertador y el general Santander. La circunstancia de la guerra había impuesto la conformación de una doble gobernación en cada uno de los territorios: un gobernador militar que ejercería además del mando de las armas, la alta policía y todas las funciones gubernativas, $y$ otro gobernador político encargado ini- 
cialmente de la parte contenciosa como jueces de primera instancia y la baja policía, quienes poco después, fueron también encargados de los asuntos de hacienda o justicia. La meta del Libertador era asegurar las provincias que se fueran liberando mediante el establecimiento de "una forma de gobierno central que fuese enérgico, activo y vigoroso, que concentrase los recursos y fuese capaz de evitar nuevas desgracias" (Martínez, 2008, p.37).

\section{Período centralista por la campaña libertadora (1819-1824)}

EI 2 I de septiembre de 1819 comenzó la primera administración del general Santander, inicialmente de las provincias Libres de la Nueva Granada y desde la Ley Fundamental de la República de Colombia (17 de diciembre de 1819), surgida entre las deliberaciones del Congreso de Angostura, del nuevo departamento de Cundinamarca. La Ley Fundamental también mandó a convocar el Primer Congreso General de la República de Colombia, el cual pudo ser instalado el 6 de mayo de I82I en la Villa del Rosario de Cúcuta.

En medio de candentes debates, la Constituyente de Cúcuta decidió una fórmula de organización centralista para el Estado de la naciente Republica de Colombia (la Gran Colombia). La Constitución de la República de Colombia (30 de agosto de 182I) adoptó un gobierno republicano, popular, con división de poderes (ejecutivo, legislativo y judicial) (Restrepo, 2010, p. 52). El 3 de octubre de I82I, se posesionan Bolívar como Presidente y Santander como Vicepresidente de la República de Colombia,

El Congreso de Cúcuta fue mucho más allá que el estatuto de unión de Angostura que había mantenido los tres territorios de Venezuela,
Nueva Granada y, eventualmente Quito, como entidades separadas, bajo el mando inmediato de vicepresidentes regionales. El primero de los departamentos fue ahora dividido en las provincias de Orinoco, Venezuela y Zulia y, el segundo, en Boyacá, Cundinamarca, Cauca y Magdalena. Las provincias estaban conformadas por cantones y estos por parroquias, todas sujetas a las autoridades centrales.

El engranaje básico del gobierno regional lo ejercería el nuevo mecanismo de los Intendentes encargados de los distintos departamentos, quienes eran nombrados por el Presidente de la República con la aprobación del Senado. El mando de los departamentos recayó en los intendentes, casi todos militares, y la función judicial fue ejercida por abogados profesionales para garantizar la división de poderes. Los intendentes de los departamentos y los gobernadores de las provincias estuvieron acompañados por un juez de Hacienda, un secretario y algunos oficiales auxiliares para administrar la Hacienda pública. Los cantones (hoy municipios) quedaron sin rentas propias, por lo que dependían de los servicios ofrecidos por los intendentes.

Pero no necesariamente la separación republicana de los tres poderes se aplicaba hasta los niveles inferiores del gobierno. Los intendentes y gobernadores provinciales tenían algunas funciones judiciales y también fue dado que las funciones civiles y militares podían ser desempeñadas por una misma persona. Se considera que estas disposiciones eran una consecuencia de los tiempos de guerra, pero que dieron lugar a más de un conflicto respecto a los principios republicanos (Bushnell, 1985, p.38).

En el centro del gobierno, el poder estaba distribuido entre el Presidente, dos cámaras legislativas y una Alta Corte. El control que 
ejercía el Presidente sobre la administración central y departamental le hacía aparecer en supremacía teórica del poder. Ello debió parecer innegable cuando ante cualquier situación de emergencia las Cámaras hacían uso del procedimiento de las facultades extraordinarias consagradas en el artículo 128 de la nueva Constitución. Es dentro de los límites de este artículo que la Ley del 9 de octubre de I82I concedió indefinidamente facultades al Libertador para "organizar el país según que se vayan liberando nuevos territorios del modo que lo crea conveniente" (Bushnell, 1985, p.35).

La Constitución de la República de Colombia expedida en agosto de I82I, ordenaba en la Sección II sobre atribuciones especiales del Congreso, que esa rama del poder público debía desarrollar las siguientes tareas:

I. Fijar los gastos públicos anuales

2. Decretar la administración y enajenación de los bienes nacionales

3. Decretar los impuestos y contribuciones

4. Autorizar las deudas públicas de la República

5. Establecer un Banco Nacional

6. Fijar la moneda nacional

7. Fijar y uniformar pesas y medidas

8. Crear las Cortes de Justicia y los juzgados inferiores de la República

9. Decretar la creación o supresión de los empleos públicos, señalarles sueldos, disminuirlos o aumentarlos

10. Establecer reglas de naturalización

II. Conceder premios y recompensas personales a los que hayan hecho grandes servicios a Colombia

12. Decretar honores públicos a la memoria de los grandes hombres.
Cuando finalmente ganó Bogotá para ser capital de la República, al Congreso le quedaba la tarea de elegir miembros para el primer Senado y la primera Cámara. Los senadores tenían un período de ocho años y debían ser elegidos en forma parcial en cada elección. Con el objeto de tener la nómina completa para la primera reunión, los diputados de Cúcuta decidieron conveniente elegir ellos mismos los miembros de toda la corporación. La Cámara fue provista desde el principio mediante elección popular indirecta. Bolívar por su parte completó esta administración nombrando formalmente el gabinete de secretarios, antes de traspasar a Santander el control ejecutivo: secretario del Interior a José Manuel Restrepo, antioqueño, y como secretario de Hacienda a José María del Castillo y Rada, cartagenero. A los venezolanos Pedro Gual como Secretario de Relaciones Exteriores y Pedro Briceño Méndez como Secretario de Guerra, quienes fueron posteriormente cambiados por sus compatriotas José Rafael Revenga y Carlos Soublette (Bushnell, 1985, p.40).

La Carta Magna de I82I dispuso que todos los ciudadanos estaban obligados a contribuir a los gastos del Estado (art. 5) y señaló que era responsabilidad del Congreso fijar anualmente los ingresos y gastos de la República, así como establecer los mecanismos precisos para su adecuada gestión (art. 55). Lo más novedoso de esta carta fue sin duda alguna la presentación de un presupuesto de gastos ex-ante para aprobación previa del Legislativo, y la posibilidad, en todo tiempo, de la reforma de los tributos nacionales (López, 1992, p.35I). Sin embargo, nada explícito se dijo sobre la manera de establecer los ingresos, ni el modo de distribuir los recursos públicos del Estado entre los respectivos departamentos, provincias, cantones y parroquias. 
La Ley $8^{a}$ de octubre de 1821 autorizó al Ejecutivo para que organizara las diferentes oficinas de la Hacienda de la naciente República. El I 2 de diciembre de 182 I, el general Francisco de Paula Santander, Vicepresidente encargado del Ejecutivo, expidió el decreto que organizó la Tesorería General de la Republica para que desempeñara las funciones de recaudar y custodiar los fondos públicos de la República. Del Secretario de Hacienda el señor José María Castillo y Rada quedaron dependiendo el ministro tesorero Juan de Dios Olano, el ministro contador Luis Carbonell y un Oficial Mayor que tenía a su cargo un expendedor de papel sellado, dos escribientes, un escribano, siete oficiales y un portero. El mismo día en que se estableció la oficina del Tesoro Público en Bogotá, por sendo decreto el Vicepresidente organizó la Contabilidad General de la República, encargando de esta labor a cinco contadores generales, uno como decano y los otros dependientes (López, 1992, p.23).

La Ley del 12 de octubre estableció tres distritos judiciales correspondientes a las tres comprensiones judicial y militar en que fue dividido el país con el fin de administrar justicia de una manera más eficaz en todo el país: el del Norte en Caracas y el del centro en Bogotá, quedando pendiente el del Sur en Quito, lo cual significaba una innovación que permitía tramitar las apelaciones locales con mayor facilidad. La administración de justicia recaía sobre una Alta Corte que incluía algunas de las mejores inteligencias de la República. Los tres primeros Magistrados de la Alta Corte fueron los colombianos: doctor Félix Restrepo y doctor Jerónimo Torres, y el venezolano doctor Miguel Peña. Los dos primeros fiscales fueron el colombiano doctorVicente Azuero y al venezolano doctor Leandro Egea. A pesar de algunas excentricidades lamentables del Distrito del Centro, el de Caracas tuvo cierta influencia estabilizadora sobre la sección más turbulenta del país. Si bien los magistrados republicanos estaban obligados a respetar las leyes y los derechos de los ciudadanos, no por ello la calidad de la justicia significaba la realización de la utopía republicana en mayor medida que en cualquier otro aspecto de la vida nacional.

De todos modos, la construcción del poder judicial implicaba un esfuerzo muy grande debido al choque cultural entre la anterior justicia indiana (un sistema jurídico autoritario-represivo) en manos de los agentes del poder ejecutivo y la nueva del régimen republicano (basado en los medios técnicos de la burocracia judicial) en la que para el común, sus funciones separadas del Ejecutivo hacían del juez un miembro inferior (Martínez, 2008, p.l I5). Por su parte, el ejercicio de la justicia se iba haciendo más complicado por cuanto la cesación paulatina de la guerra, iba dejando una legión de vagabundos desertores y veteranos desadaptados junto a hordas de nuevos funcionarios, diplomáticos extranjeros y aventureros de todas clases (Bushnell, 1985, p.7I).

En materia hacendal, desde un comienzo los legisladores tuvieron la intención de expandir los impuestos directos sobre las rentas y ganancias de los ciudadanos, siguiendo las directrices de la teoría liberal, para la cual los impuestos directos son la base de una ciudadanía responsable, consciente de sus derechos y obligaciones con el Estado.

Debe reconocerse que la Ley 30 de I82I era una excelente demostración de manejo fiscal relativamente innovador pues las reducciones o eliminaciones de tributos indirectos se hicieron sobre la base de que se buscaría una compensación a través del establecimiento 
de un impuesto directo sobre las rentas y los capitales. Mas este novedoso impuesto directo, a la postre apenas tuvo una vida efímera y de poco rendimiento fiscal (Restrepo, 2010, p.81).

En efecto, este primer impuesto a la renta que existió en Colombia consistió en una tributación del $10 \%$ anual sobre los ingresos producidos por la tierra ( $12,5 \%$ si la tierra no era enajenable) y el capital, y del 2 al $3 \%$ sobre los ingresos personales como los salarios gubernamentales, según su monto (Restrepo, 2010, p.82), gravamen del cual quedaban exentos los propietarios cuyos bienes no excedieran de $\$ 100$. Cada contribuyente debía presentar una declaración pública del patrimonio, sujeta a la revisión de un comité de ciudadanos respetables, en la que la renta presuntiva del capital invertido en la minería o en las manufacturas era del $5 \%$, la del capital comercial el $6 \%$ y la de los bienes inmuebles el $5 \%$ (es decir que el impuesto por la renta de los inmuebles ascendería al medio por ciento).

Por la época en que se clausuraron las sesiones del Congreso de Cúcuta en octubre de 182I, Quito permanecía en manos de los españoles pero ya Guayaquil gozaba de gobierno independiente. La tarea pendiente era complicada por cuanto estos territorios habían sido incluidos en la República de Colombia sin el consentimiento de sus representantes. En noviembre de I82I, mientras Bolívar estaba preparando una campaña sobre el istmo, los panameños depusieron a los españoles y solicitaron unirse a Colombia si se les concedían la conservación de todos los militares y funcionarios civiles en sus actuales cargos y el reconocimiento de las deudas que había asumido la Junta patriótica como resultado del golpe.

Ya desde el 8 de enero de 1822, agobiado el Ejecutivo por la impo- sibilidad de atender sus compromisos de pago a los militares y funcionarios públicos, había dictado el decreto que establecía rebajas de salarios y permite, que incluso tierras de la Nación, cedidas en arriendo por término indefinido a terceros, se aplicaran al pago de las deudas pendientes con el ejército del Libertador. Sobre este respecto vale la pena señalar, que así de manera muy temprana, iniciaba la política de subasta de terrenos baldíos y ocupados pertenecientes a la Nación, como único activo disponible para aliviar las presiones sobre las arcas débiles del Tesoro.

En esa misma fecha y como resultado de las preocupaciones del Secretario de Hacienda por la fuerte malversación y la defraudación de los fondos públicos, atribuida a la desarticulación administrativa de las pagadurías regionales y por los escasos soportes de rendición de cuentas, se dicta el decreto mediante el cual se organizan las tesorerías departamentales dependientes de la Tesorería General y las tesorerías subalternas provinciales dependientes de las tesorerías departamentales (López, 1992, p.24).

El funcionamiento básico de esta estructura inicial de manejo del Tesoro Público a nivel regional, se puede resumir en las siguientes tareas:

\section{Tesorerías Departamentales}

- Girar los gastos ordinarios en su jurisdicción, que hayan sido decretados por Ley o por el Gobierno.

- Girar los gastos extraordinarios ordenados por los intendentes avalados por la Secretaría del Despacho de Hacienda.

- Girar los fondos librados por la Tesorería General.

- Remitir cada cuatrimestre un estado de todos los ingresos y egresos, clasificado por gastos ordinarios y extraordinarios, 
con destino a la Tesorería General, expresando además, las cuentas pendientes por cobrar y su naturaleza.

- Entregar estados contables al cierre cada año, para revisión del Intendente Departamental.

2. Tesorerías Provinciales o foráneas

- Girar los gastos ordinarios decretados por Ley o por el Gobierno.

- Girar los gastos extraordinarios ordenados por los intendentes, previa aprobación de la Secretaria del Despacho de Hacienda.

- Cada mes presentar a las Tesorerías Departamentales, un estado circunstanciado de las entradas y salidas de fondos, expresando el ramo y tipo de gasto.

- Entregar al cierre de cada año, estados contables para revisión de los gobernadores de provincia.

Con esta organización descentralizada, la Tesorería General y las Tesorerías de la Administración de los otros ramos que también manejaban fondos públicos, rendían mensualmente cuenta ante la oficina de Contabilidad General, recibiendo cada treinta días visitas de control que se denominaron para la época "visita de arcas". Los ingresos de estas tesorerías se alimentaron específicamente de rentas de aduanas, tabacos y correos, fondos que, una vez percibidos sin ningún tipo de retenciones, se transferían a las oficinas de manejo. Particularmente, las rentas provenientes de los monopolios de aduanas y tabacos se consignaban en las tesorerías una vez se ejercía sobre ellas los descuentos por concepto de compra del producto o género, los sueldos de los funcionarios, y por último, los gastos fijos de las oficinas correspondientes (López, 1992, p.26).

Es interesante observar cómo los delegados de Cúcuta tomaron el buen cuidado de consignar que solicitarle al ejecutivo información sobre el estado de las finanzas no era ninguna muestra de censura. Estas solicitudes constituyeron la primera incursión práctica en la vida parlamentaria de lo que hoy es una prerrogativa indiscutible de los congresos, a saber, poder recabar del ejecutivo todas las informaciones que sean relevantes en materia de finanzas públicas, sin que ello se interprete desde luego, como una censura. (Restrepo, 2010, p.55)

Allí también fue acordado que la Gran Colombia asumiría la totalidad de la deuda contraída por Venezuela y Nueva Granada, creando para ello un fondo de amortización alimentado por ciertas rentas nacionales con el fin de que la nueva república readquiriera el crédito internacional (Restrepo, 2010, p.57).

Entre los respetables encargos del Libertador Presidente y del Congreso de Angostura, estuvo el que la Constituyente de Cúcuta tomara en consideración los medios de extinguir la esclavitud. La liberación de los esclavos que decreta la Convención de Cúcuta es como se sabe, parcial. Es solamente hasta mediados del siglo cuando tiene lugar la liberación total. Los principales logros consisten en: haber decretado la libertad de partos previo mecanismo de compensación a los amos, la prohibición de la venta de esclavos por fuera de la provincia en que han sido separados de los padres, la prohibición de introducir esclavos de cualquier manera que fuere $y$, la reglamentación de los mecanismos de liberaciones que cobijaría a aquellos esclavos que se enrolaran en las huestes libertadoras (Restrepo, 2010, p.6I).

Desde los días de la Primera República, el panorama sombrío de 
quiebra fiscal y de corrupción era insostenible. El régimen de Santander se vio obligado a tomar medidas drásticas, lo cual puede evidenciarse con la promulgación de la Ley principal Anticorrupción de octubre 23 de 1819 donde establecía la pena de muerte para los empleados de Hacienda Nacional comprometidos en fraude 0 malversación de intereses públicos. El Decreto del $2 \mathrm{I}$ de febrero de 1822 suspende la ejecución sumarial y la sustituye por las siguientes penas:

I. La ineptitud en el cargo castigada con destitución del empleo.

2. La negligencia en los deberes con destitución e inhabilidad.

3. El encubrimiento o la cohonestación con un defraudador castigada con 10 años de presidio.

4. El fraude con castigo de 10 años de presidio, más pérdida del $100 \%$ de sus bienes o una tercera parte de ellos si los tuviere.

En una política de freno a la inmoralidad, la administración comenzó a dar importancia a la necesidad de aumentar los salarios de los empleados públicos, pero cuando el Congreso lo autorizó finalmente, Santander vetó la ley argumentando que carecía de fondos para cumplirla (Bushnell, 1985, p. I 12).

El fin del gobierno español en Ecuador tiene lugar en mayo de 1822 lo que señala la adhesión de Quito a Colombia y el posterior despliegue de fuerza para obtener el voto de Guayaquil para la unión con Colombia. El interés de Bolívar se traslada entonces al Perú (Bushnell, 1985, p.42).

En las Memorias que presentó al Congreso en 5 de mayo de 1823, el Secretario de Hacienda, José María del Castillo y Rada, reseñaba que el presupuesto público para ese año ascendía a 5 millones de pesos y que los créditos externos solo aseguraban un millón de pesos. Las enormes necesidades surgidas de la guerra de emancipación y el sostenimiento de un ejército superior a los 10 mil hombres representaban entre el 60 y $70 \%$ de los gastos públicos de la época (López, 1992, p.30).

El último ejército regular español permaneció en Puerto Cabello hasta fines de 1823. Desde los otros territorios recién liberados era algunas veces necesario hacer frente a continuos desórdenes fomentados por agentes españoles, por grupos locales y por ocasionales guerrillas realistas. Coincidente con el avance de la revolución liberal española, muchos defensores de la Corona y la Realeza prefirieron transformarse en aliados de los patriotas. El primer congreso ordinario de 1823 autorizó la inmediata deportación de todos los sospechosos realistas y desafectos del gobierno en todas partes de Colombia

\section{La Revolución Liberal Española de 1820}

Con el pronunciamiento de la Revolución Española de 1820 por parte de los militares liberales españoles inicia el llamado Trienio Constitucional o Liberal (1820-1823). Aunque pueden detectarse alteraciones anteriores, este movimiento revolucionario suscitó el contagio y en varios casos la imitación explícita configurando la primera de las llamadas oleadas o ciclos revolucionarios que sacudieron Europa con posterioridad a las Guerras Napoleónicas y que se repitieron sucesivamente en las de 1830 y las de 1848 .

Las primeras revueltas surgieron como reacción a la Restauración que se produjo como consecuencia de la derrota de la Francia revolucionaria, y que suponía el restablecimiento del Antiguo 
Régimen y la aplicación de los principios legitimistas del Congreso deViena de 1815 , confiados a la fuerza y determinación intervencionista de la Santa Alianza, como fue denominada la mancomunidad de las monarquías absolutas. Estas revoluciones fueron protagonizadas por la burguesía surgente con el desarrollo del capitalismo, cuya clase social controlaba la nueva situación económica pero se hallaba relegada de la política en la Europa de la Restauración. Trataba entonces de acceder al poder político mediante la acción revolucionaria para suplantar la aristocracia, buscando el apoyo de las clases populares urbanas, deseosas de mejorar sus pobres condiciones de vida y trabajo, empeoradas a causa de las crisis. Los ejes ideológicos de estas revoluciones fueron el liberalismo político y el nacionalismo. Los liberales defendían los derechos del individuo a la libertad y la igualdad jurídica, un estado de derecho garantizado por una Constitución o norma fundamental, que limitara la autoridad del rey, con separación de poderes (ejecutivo, legislativo y judicial) y sufragio. La Santa Alianza, finalmente consiguió en 1823 sofocar los levantamientos españoles y la generalización del contagio revolucionario.

El pronunciamiento del coronel Rafael de Riego, puesto al frente de las tropas acantonadas en Las Cabezas de San Juan (localidad de la provincia de Sevilla, el I de enero de 1820, desencadena el triunfo de la revolución liberal en España, que impera durante el trienio liberal (1820-1823). Unas nuevas Cortes retomaron la obra legislativa gaditana, con el claro propósito de acabar con las bases económicas, sociales y políticas del Antiguo Régimen (desamortización, supresión de señoríos y mayorazgos, de la Inquisición, etc.) y además, la proclamación en 1820 de la Constitución de Cádiz de 1812 , traía consigo un nuevo centralismo: todo el poder en "la Nación" o Estado monolítico.
Ante los riesgos de falta de apoyo por parte del resto del ejército $y$ de las ciudades más importantes, entre las formas de lucha de los revolucionarios de 1820, predominó la conspirativa a través de sociedades secretas, similares a la masonería, como los carbonarios. Estos revolucionarios españoles también buscaban apaciguar la insurrección de América y hacer innecesaria la guerra de la que así se librarían los soldados, lo que directa o indirectamente contribuiría a incrementar la insurrección en América. A su vez, para los jóvenes revolucionarios, en el caso de triunfar, el separatismo vendría a significar la consolidación del poder de la oligarquía criolla.

A comienzos de marzo, mientras se iban dispersando las tropas de Riego y Quiroga, estalló una insurrección liberal en Galicia que se expandió por todo el país, lo que a la postre se convirtió en una verdadera revolución. Una muchedumbre rodeó el Palacio Real de Madrid el día 7 de marzo, y Fernando VIl, viéndose acorralado, esa misma noche firmó un decreto por el que se sometía a la voluntad general del pueblo, y tres días más tarde juró finalmente la Constitución de Cádiz, incluyendo la famosa frase: Marchemos francamente, y yo el primero, por la senda constitucional.

En contrario, surge la sublevación de los realistas, defensores de la realeza, la cual cristaliza en 1822 dando lugar a una guerra civil. Los realistas eran de ideas tradicionales que parten de la idea de que la libertad y la justicia solo se pueden conseguir si se basan en la religión, en la Iglesia Católica; por ello los liberales optaron por llamarles absolutistas. Al tiempo, la Santa Alianza se reunía en el Congreso de Verona en 1822 y decidió que Francia invadiese España para ayudar a Fernando VIl y restaurar el absolutismo. Francia envió el 7 de abril de 1823 un cuerpo expedicionario que los liberales denominaron 
los Cien Mil Hijos de San Luis, al mando del Duque de Angulema. Ese ejército, al que se unen los realistas cuando pasa la frontera en 1823, propició el acorralamiento de las cada vez menos numerosas fuerzas leales al gobierno liberal quienes se fueron retirando hacia el sur llevándose como rehén a Fernando VII, hasta que, tras la batalla de Trocadero ( 31 de agosto), acaba la última resistencia liberal habiendo soportado el bombardeo de Cádiz durante varios días y liberado el rey antes de huir al exilio. El rey se apresura a anular toda la legislación del Trienio Constitucional, empezando por la Constitución de Cádiz de 1812 alegando que al aceptarla había obrado por la fuerza y que por lo tanto eran nulos todos sus actos.

\section{La independencia del Perú}

Para llevar adelante la independencia del Perú, se firmó el 5 de febrero de 1819 un tratado entre Argentina y Chile. Se organizó una fuerza militar anfibia que en un principio sería financiada conjuntamente por los gobiernos de Argentina y de Chile, pero debido a la situación de anarquía en las provincias rioplatenses, el gobierno de Buenos Aires se desentendió de los presupuestos, siendo la casi totalidad de los costos asumidos por el gobierno de Chile dirigido por Bernardo O'Higgins. Se determinó que el mando del ejército fuera para José de San Martín y de la escuadra para el almirante Thomas Alexander Cochrane. El general José de San Martín creía que la independencia de las Provincias Unidas del Río de la Plata no estaría totalmente segura mientras el Perú fuera un importante bastión de las fuerzas realistas.

En abril de 182I, el virrey La Serna, mal de su grado, pero obligado por las instrucciones traídas desde España por el comisionado Abreu, en el sentido de llegar a un acuerdo pacífico con los patriotas, invitó oficialmente a San Martín a entrar en negociaciones, lo que el general argentino aceptó. Los delegados patriotas fueron instruidos para que se abstuviesen de llegar a algún acuerdo en tanto que no fuese reconocida la independencia de las Provincias Unidas de Río de la Plata, Chile y Perú. Como ya había ocurrido en las anteriores conferencias de Miraflores, los españoles se mantuvieron inflexibles en no reconocer la independencia, lo que hacía que ambas partes se enquistaran en posiciones insalvables. Se decidió solo un armisticio de 20 días y se programó una entrevista personal entre los jefes adversarios, es decir entre La Serna y San Martín.

La entrevista entre La Serna y San Martín se realizó el 2 de junio. Acompañaban al virrey, el general José de la Mar y los brigadieres José de Canterac y Juan Antonio Monet. Por su parte, San Martín estaba acompañado por el general Gregorio de las Heras, Mariano Necochea y Diego Paroissien. Según testimonio del comisionado Abreu, el plan que San Martín expuso al Virrey consistía esencialmente en lo siguiente: que se instalaría una regencia, de la que La Serna sería Presidente y que estaría, además, integrada por un vocal nombrado por el Virrey, y otro nombrado por San Martín. Los dos ejércitos beligerantes deberían unificarse y se declararía la independencia. Luego, San Martín en persona viajaría a Madrid para solicitar de las Cortes que escogieran a un infante de España, un príncipe Borbón, que debía ser proclamado Rey del Perú. En un primer momento, a La Serna no le pareció inaceptable este plan y consideró incluso la voluntad de San Martín de ir a España como un gesto de buena voluntad. Al parecer, esa también fue la primera impresión de sus oficiales, que departieron con los delegados patriotas en medio de brindis y chanzas. El Virrey pidió dos días para consultar a todos sus oficiales $y$, según parece, se impuso entonces el criterio de sus 
dos oficiales más importantes, Canterac y Valdés, que vieron en el plan de San Martín solo un pérfido ardid para ganar tiempo. La Serna se abstuvo de dar una respuesta a San Martín, aduciendo que no tenía instrucciones para decidir en asuntos tan trascendentes.

El día 28 de junio de $|82|$, el general rioplatense José de San Martín, jefe de la Expedición Libertadora proclamó la independencia del Perú en Lima, la capital del hasta entonces Virreinato del Perú. Tras proclamar la independencia del Perú, San Martín asumió el mando político y militar de los departamentos libres del Perú, bajo el título de Protector, según Decreto del 3 de agosto de I82I. El 27 de diciembre de 1821 , San Martín convocó por primera vez a la ciudadanía con el fin de que eligiera libremente un Congreso Constituyente, el cual se instaló en I de mayo de 1822, con la misión de establecer la forma de gobierno que en adelante regiría al Perú, así como una Constitución Política adecuada.

El 9 de octubre de 1820 estalló un movimiento independentista en Guayaquil que instaló una Junta de Gobierno independiente y proclamó su independencia, declarándose integrante del Perú. Mientras tanto, el Libertador Simón Bolívar emprendía viaje a Popayán, en diciembre de 182I, para acabar con la resistencia pastusa.

Para intentar la conquista de Quito las fuerzas grancolombianas tendrían que plantearse dos batallas: una contra los propios patriotas, que siendo partidarios de la independencia veían con reticencia su integración en Colombia y otra contra los realistas. El general Antonio José de Sucre fue enviado por Bolívar, junto con un millar de hombres, para en primera instancia apoyar la revolución contra las fuerzas realistas bajo el mando del general Aymerich, y poste- riormente convencer a los patriotas de la conveniencia de unirse a Colombia, lo que aceptaron al fin como una solución provisional. En Quito, Sucre se vio atrapado en un laberinto político, estorbado no solo por los realistas que le cerraban el camino a la capital, sino por las distintas facciones que peleaban dentro de Guayaquil, dividida como estaba entre quienes querían la independencia tanto respecto de Colombia como de España, y los que pedían la unión con el Perú. Pero Sucre necesitaba de los insurgentes de Guayaquil y estos necesitaban de Sucre y de Colombia. Así, sin mencionar el estatuto de Guayaquil se firmó una alianza en mayo de 1821. Sucre podía defender la costa de modo efectivo, pero continuaba sin tener el poder para pasar por las tierras altas hasta Quito, $y$ en ese frente quedó encantado de aceptar un armisticio en noviembre de I82I. Protegida por la cordillera por el Oeste, Quito era también inexpugnable desde el Norte, donde los enclaves realistas cerraban los pasos de montaña a la revolución. Desde Guayaquil, el grancolombiano Antonio José de Sucre solicitó la ayuda de José de San Martín, que puso entonces en marcha la Expedición Auxiliar de Santa Cruz a Quito desde Piura el 15 de enero de 1822.

Las tropas del general San Martín acantonadas en Guayaquil se organizaron para abatir los últimos baluartes del poderío español. El día 22 de abril de 1822, al mando de las argentinas y chilenas, el general bonaerense Lavalle expulsa a los realistas de Riobamba. Las tropas restantes, unidas a los guayaquileños y a los patriotas del interior, al mando del futuro mariscal de Ayacucho logran el armisticio de Babahoyo y, desde Santa Rosa, barren los últimos retazos del dominio español en las provincias de Loja y Cuenca. Finalmente Sucre, tras atravesar las alturas de la cordillera en abril de 1822, en vez de atacar por el Sur como se esperaba, avanzó desde el Norte, 
y el 24 de mayo dio la gran batalla del Pichincha, con su extinguido volcán cubierto de nieves eternas, que fue un gran triunfo patriota y supuso la liberación del territorio que luego sería ecuatoriano. Sucre entraba victorioso en Quito y aceptaba la rendición del gobernador Aymerich.

Tras arduos combates logró entrar en Pasto en junio de 1822. Posteriormente se produjo la Entrevista de Guayaquil, el 26 de julio de 1822, y los dos libertadores discutieron sobre el destino de la Provincia Libre de Guayaquil (si debía pertenecer a la Gran Colombia o al Perú), la ayuda que debía prestar la Gran Colombia a la independencia del Perú y sobre el sistema político que se instalaría en el Perú: Monárquico independiente como deseaba San Martín o Republicano como quería Bolívar. Pero el General bonaerense no podía esperar una fácil solución ya que la asociación con el Libertador planteaba más problemas que los solucionables: puso a discusión la base entera de la colaboración militar, exacerbó el asunto de la monarquía frente al republicanismo, e introdujo el problema del conflicto de intereses por Guayaquil. Esta era una importante base naval, un centro de construcción de buques y un puerto importante que estratégica y comercialmente era indispensable para la revolución y de gran importancia para los intereses de la República de Colombia que representaba Bolívar.

Tras el golpe de mano de Sucre y su victoria en Pichincha, Bolívar era el que proponía y el que disponía. La entrevista se saldó favorablemente para Bolívar que ratificó la anexión de Guayaquil a la Gran Colombia. Los dos generales querían contar con este estratégico centro neurálgico: San Martín lo quería para Perú, aunque reconocía su derecho a decidir su propio futuro político; Bolívar, por su parte, sostenía que debía unirse a Colombia sobre la base de que la presidencia de Quito, en donde se incluía la provincia de Guayaquil, había pertenecido al virreinato de Nueva Granada y lo consideraba como materia no negociable.

Lo tratado lo conocemos por la correspondencia posterior entre ambos personajes y por fuentes indirectas. San Martín le pidió ayuda militar a Bolívar y se ofreció, como posibilidad, a estar bajo sus órdenes en la campaña del Perú. Entre lo primero, Bolívar ofreció una fuerza auxiliar grancolombiana de 2000 hombres, lo cual se había concretado con el envío de tropas al mando de Juan Paz del Castillo, que San Martín consideró insuficiente y en cuanto a lo segundo, Bolívar se negó a aceptarle como subordinado, ofreciéndole poco más de mil hombres. Quito aceptó integrarse a Colombia, pero Guayaquil siguió defendiendo su independencia, por lo que el Libertador tuvo que ir personalmente a dicha ciudad a recibir la declaración de la anexión de la ciudad de Santiago de Guayaquil a Colombia, en 31 de julio de 1822. San Martín interpretó que su presencia era un obstáculo para la liberación del Perú que pensó emprendería Bolívar en cuanto desapareciera y decidió salir de la campaña en septiembre de 1822.

Las relaciones del Perú con la Gran Colombia entraron en su punto más crítico debido a la anexión de Guayaquil a territorio grancolombiano. A ello se sumó el hecho de que el oficial colombiano Juan Paz del Castillo recibiera instrucciones de su gobierno de no comprometer a sus fuerzas sino solamente en caso de que el éxito estuviera garantizado y únicamente en el norte peruano, por lo que entró en conflicto con los intereses del Perú, que se enfocaban en atacar a los realistas del centro y del sur. 
En septiembre de ese año, Bolívar ofreció a la Junta Gubernativa Provisional presidida por el general José de la Mar, otros 4.000 soldados más, pero esta Junta solamente aceptó la recepción de 4.000 fusiles. Paz del Castillo retornó a su patria, en enero de 1823, disgustado al no lograr imponer sus condiciones. Las relaciones con la Gran Colombia se enfriaron entonces, en los precisos instantes en que se libraba la llamada Primera Campaña de Intermedios. Bolívar, tras acabar con la resistencia de los pastusos en la batalla de Ibarra, embarcó un ejército de buen tamaño con rumbo al Callao, con anterioridad a su propia partida en agosto de 1823 , y haciendo su entrada a Lima el I de septiembre de 1823. El I0 de septiembre el Congreso peruano decidió entonces solicitar la intervención del Libertador Simón Bolívar.

Tras los reveses de los patriotas en la segunda campaña de puertos intermedios surgió una pugna entre el presidente Riva Agüero y el Congreso. En Lima, en 12 de noviembre de 1823, el Congreso nombró en reemplazo de Riva Agüero a Torre Tagle (el mismo que proclamara la independencia de Trujillo), que se convirtió así en el segundo Presidente del Perú. El día 14 de noviembre el Congreso de Lima confirmó a Bolívar la suprema autoridad militar en toda la República. Para entonces, ya Bolívar había enviado antes al general Antonio José de Sucre, quien mantuvo la autonomía de las agrupaciones militares de Colombia, sin comprometerlas en las campañas de intermedios.

El único obstáculo para Bolívar era Riva Agüero, quien dominaba el norte del Perú, con capital en Trujillo. Riva Agüero no dio señal de querer llegar a un acuerdo que posibilitara la unificación de todas las fuerzas patriotas del Norte bajo el mando del Libertador,y más bien quiso entenderse con los realistas. El mismo Bolívar abrió campaña contra Riva Agüero, marchando al norte. Pero antes de que se desatara la guerra civil, Riva Agüero fue apresado por sus propios oficiales encabezados por el coronel Antonio Gutiérrez de la Fuente, quien, desobedeciendo la orden de fusilarlo, lo desterró a Guayaquil ( 25 de noviembre de 1823). Bolívar entró a Trujillo en diciembre de 1823 y quedó así dominando la escena política y militar del Perú.

A finales de 1823 pedía Bolívar 12.000 hombres más, incluyendo 1.000 llaneros. En febrero del año siguiente, el número se elevó a 16.000 en cuya petición incluía un grupo de oficiales navales completamente equipados. Después de 1823, cuando comenzaron en Colombia los procesos legislativos normales, muchas de las más amplias concesiones de poder caducaron, pero el control discrecional sobre las fuerzas armadas fue prolongado provisionalmente y abundantes tareas heterogéneas le fueron asignadas al Ejecutivo. Según informe del presidente Santander a la Cámara de Representantes en 23 de abril de 1824, decía carecer de autorización legal para enviar tropas y abastecimientos fuera del país, a lo que en poco más de un mes de la reanudación de sesiones, el Congreso en 6 de mayo de 1824 autorizó al Vicepresidente para que Bolívar recibiera unos 12.000 hombres.

No hay pruebas de que Santander hubiese dudado en algún momento de la importancia que tenía para Colombia la terminación de la guerra con el Perú, pero en un segundo mensaje de Santander al Congreso el 17 de mayo de 1824 preguntaba I) Si Bolívar en el Perú, conservaba legalmente las facultades extraordinarias que le había otorgado el Congreso de Cúcuta; 2) Si esas facultades podían ser ejercidas en el Ecuador por Bartolomé Salom, a quien Bolívar las 
había delegado antes de partir para el Perú; 3) Si Bolívar podía dar órdenes a los oficiales que estuvieran en el Ecuador y en Colombia, y 4) Si los ascensos que había concedido en las tropas colombianas en el Perú serían válidas cuando las tropas regresaran al país.

De acuerdo con este alegato, el Congreso decidió, en 18 de junio, retirar la concesión de facultades extraordinarias otorgadas a Bolívar en Cúcuta, reemplazándola por otra ley más cuidadosa que quitaba las provincias recién liberadas de la lista de zonas en donde podía utilizarse las facultades extraordinarias y permitía la declaración del estado de sitio en las provincias que presentaban una amenaza de invasión o revolución. Los poderes de Bolívar fueron anulados en lo que concernía a los primeros tres puntos, por lo que el Vicepresidente asumiría la responsabilidad administrativa en su totalidad, exceptuando aquellas regiones donde Bolívar estuviera dirigiendo la guerra (Bushnell, 1985, p.52).

Santander quiso atribuir toda la responsabilidad por la elaboración de la ley al Congreso achacándole principalmente cierto disgusto por las promociones militares concedidas en virtud de los poderes de emergencia, por Bolívar, o por él mismo. Bolívar en cambio, se ofendió inmediatamente con la ley sobre todo al ver que era despojado de su poder sin recibir siquiera una palabra de agradecimiento, y más bien con una desatinada declaración en el preámbulo acerca de los inconvenientes de las facultades extraordinarias.

Mientras tanto, la Restauración absolutista en España causó la división en las filas realistas, lo que se hizo evidente con la sublevación del 22 de enero de 1824 del general Pedro Antonio de Olañeta en el Alto Perú. Aprovechando esta coyuntura, Bolívar abrió campaña contra el ejército realista más cercano, que era el de José de Canterac, el cual estaba acantonado entre Jauja y Huancayo. Al amanecer del 6 de agosto, ambos adversarios -Canterac y Bolívar- convergían al extremo sur del lago sobre la ciudad de Reyes (hoy Junín). La batalla duró unos 45 minutos; fue un combate cuerpo a cuerpo, con arma blanca (lanzas y sables), sin que se utilizaran armas de fuego. Murieron 254 realistas y 143 insurgentes. 80 realistas fueron tomados prisioneros. Bolívar, que había dado por segura la derrota y se había alejado del campo, recibió de pronto el parte enviado por Guillermo Miller en que se anunciaba la victoria.

Tras la victoria de Junín, Bolívar regresó a Lima para recibir otro ejército de refuerzo, delegando al general Antonio José de Sucre el mando del excelente ejército patriota de 8.500 veteranos americanos y voluntarios extranjeros, y ordenándole, en caso de peligro, replegarse desde la línea del río Apurimac, obtenida en el avance patriota desde Junín. El 7 de diciembre de 1824, dos días antes de la batalla de Ayacucho, como jefe de Estado de Perú, Simón Bolívar dirige una convocatoria a los gobiernos de Colombia, México, el Río La Plata, Chile y Guatemala, para instalar una Asamblea de Plenipotenciarios en Panamá, para crear una confederación de los pueblos iberoamericanos. Salvo Cuba y Puerto Rico, toda la América hispana era finalmente libre, luego de décadas de sangrientas guerras contra el poder colonial.

El 9 de diciembre de 1824 se libró la batalla de Ayacucho, que fue el encuentro final por la Independencia del Perú. El ejército patriota estaba dividido en tres divisiones: una peruana, al mando de José de la Mar (que incluía la Legión Peruana); y dos divisiones colombianas, al mando respectivamente de Jacinto Lara y José María Córdova. La 
victoria de Ayacucho determinó el final del virreinato del Perú, que se concretó con la firma de la capitulación de Ayacucho.

\section{Período de ordenación fiscal federalista (1824-1826)}

Las cinco legislaturas constitucionales que se sucedieron durante el tiempo colombiano (1823 a 1827), mantuvieron la mayoría de los impuestos indirectos, muchos heredados de tiempos indianos (Pérez Herrero, 20I I, p.5).

\section{Las reformas fiscales entre 1824 y 1826}

Una vez que las regiones del Ecuador fueron libres, el Gobierno se vio en la necesidad de reglamentar el territorio nacional. La Ley de División Territorial del 25 de junio de 1824 establece 12 departamentos definiendo las capitales y cantones pertenecientes a cada uno.

La primera ley orgánica de la República de una lista enorme de reformas encaminadas al desarrollo de las instituciones gubernamentales es la Ley 197 dictada el 3 de agosto de 1824 mediante la cual el Congreso suprimió la Contaduría y la Tesorería General de Hacienda reemplazándolas por la Dirección General de Hacienda y Rentas Nacionales. $A$ esta se le asignó la misión de reunir la normatividad referente al manejo de la Hacienda Pública y, para tal fin, se estipuló que se debería unificar la manera de llevar los libros de cuenta y razón y el fenecimiento de las cuentas. También se crearon las contralorías departamentales, asignándoles las funciones de remitir a la Dirección General, en los primeros días del mes de octubre, la relación de las cuentas glosadas, sentenciadas y fenecidas, así como también los resultados de cada juicio y se les asignó la competencia para ejecutar por la jurisdicción coactiva las cuentas fenecidas.
Hay que resaltar que estas dos primeras leyes se redactan en una época en que la situación fiscal de la Gran Colombia era bastante dramática debido al endeudamiento causado por la Independencia. Adicionalmente, el manejo de la Hacienda Pública no era muy eficiente, lo que motivó a que el general Santander prescribiera que los empleados que estuvieran inmersos en actividades de corrupción pudieran ser destituidos con la sola sospecha, regulación que fue ratificada por el Congreso en 1826, pero que no tuvo mucha eficacia, ya que muy pocos funcionarios fueron sancionados.

Los siguientes son los puntos más importantes de la Reforma (López, 1992, p.30).

I. Se crea la Dirección General de Hacienda y Rentas Nacionales dependientes de la Secretaría de Hacienda, apoyada por cinco directores especializados.

2. Se crean las Administraciones de Hacienda en cada departamento regidas por un intendente, para dirigir los procesos de recaudación y distribución de las rentas públicas en cada región.

3. Se crea en cada departamento una contaduría departamental para que examine, glose y fenezca las cuentas de las tesorerías principales y subalternas.

4. Se crea en cada departamento una tesorería departamental coordinadora de las tesorerías foráneas o de provincia. Los colectores de rentas dependían de estos despachos y su sueldo era a destajo, como un porcentaje de su esfuerzo de recaudo que no podía exceder un $6 \%$ del producto recolectado.

5. Se establecieron las Juntas de Hacienda, integradas por el intendente, con contador y tesorero departamentales para que en forma especial aprobaran gastos extraordinarios que por su urgencia no dieran tiempo a ser consultados con el poder ejecutivo central. 
6. Se ordenó crear las oficinas de Aduanas en los puertos que se juzgaran procedentes, como oficinas independientes de las tesorerías. Estas se conformaban por una planta mínima de personal que contaba con un administrador, un contador $y$ un guarda almacén.

7. Se crearon los resguardos en los puertos, con un comandante y un número de ayudantes proporcional a la extensión del puerto y la costa.

8. Ordenaba el funcionamiento de las Administraciones de Rentas del Tabaco en cada departamento coordinando las factorías y los estanquillos de distribución.

9. Reordenó los tres distritos de correos, creando en cada departamento una administración independiente.

10. Mantuvo las casas de moneda existentes como dependientes de la Dirección General adscrita a la Secretaría de Hacienda y ordenó recuperar del deterioro las máquinas de acuñación para facilitar sus labores.

El principal problema que encontró esta estructura hacendal de corte descentralizado era hallar edificaciones acordes para el desarrollo de las diferentes dependencias departamentales, por cuyo motivo el II de agosto de 1824 el Senado y la Cámara de Representantes aprobaron una norma autorizando la adquisición de casas para instalar los despachos de las tesorerías y contadurías generales.

A raíz del constante embate de guerrillas realistas y por el reinante temor ante una supuesta "Santa Alianza" entre Francia y España para recuperar las colonias americanas, el 31 de agosto de 1824 el Ejecutivo decretó un alistamiento general de todos los ciudadanos entre los 16 y los 50 años en el país, exigiéndole al departamento de Venezuela un contingente de 50.000 hombres para ser enviados a Bogotá. El general José Antonio Páez, Comandante General del Ejército en Venezuela demoró la ejecución del decreto por casi un año, temeroso no solamente de un motín general sino para así demostrar su desagrado ante las decisiones del Gobierno Central (Márquez, Franco y Murillo, 2013, p.7).

La Ley del 2 de mayo de 1825 aclaró que el primer período constitucional de la administración del poder público de Colombia se extiende desde el 2 de enero de 1823, día en que según la Constitución el Congreso debe declarar las personas nombradas en los empleos de Presidente y Vicepresidente y el mediodía del 2 de enero de 1827. De este modo, el período transcurrido desde el 3 de octubre de $I 82 \mid$ y el 2 de enero de 1823 fue considerado extraordinario.

La legislación que se elaboró en la Ley Orgánica del II de mayo de 1825 trató de asegurar tanto la separación formal de los poderes Ejecutivo y Judicial ordenando la existencia de una Alta Corte en la capital y la creación de Cortes Superiores de Justicia en cada uno de los departamentos. Los asuntos judiciales de los intendentes y gobernadores distritales fueron transferidos a estos nuevos magistrados denominados jueces letrados de hacienda. En el nivel municipal, al lado del juez letrado de primera instancia estaba el agente del Ejecutivo nacional ahora con el nombre de Jefe Político y el comandante de plaza si la ciudad tenía guarnición militar. Un cálculo del Secretario del Interior mostró que el número de estos en toda la República ascendía a 200, lo cual crearía un problema fiscal si se decidía asignarles salario, dada la inexistencia de rentas propias en buena parte de los cantones (Martínez 2008, p. 143). 
Desafortunadamente, en los gobiernos locales los alcaldes retenían todavía el conocimiento de los casos de menor importancia e intentaban rivalizar con los jueces letrados. También, la prolongación de la guerra había hecho difícil encontrar reemplazos capaces para tales cargos. La escasez de buenos candidatos para los empleos no hacía posible llevar a cabo en todas partes una reforma como la de instituir los jueces letrados, aunque hubiesen estado disponibles los fondos necesarios. Además, los salarios eran pocas veces halagadores y debido a los gastos militares, solamente en ocasiones podían pagarse completamente. De hecho, los bajos sueldos no permitían mantener un alto nivel de eficacia y honestidad en el servicio público.

Los liberales convencidos pujaban para que fuesen creadas Cortes Superiores para cada departamento y situar un juez letrado de hacienda o de primera instancia en cada cantón con el fin de librar a la Nación del crimen. Otros clamaban por modificar la justicia por medio de audiencias sumarias y penas más severas. Al final el Congreso trató de satisfacer ambas posiciones creando los cargos $y$, por falta de fondos y de abogados, el Gobierno ni siquiera intentó establecer las Cortes Superiores legalmente autorizadas en tres de los doce departamentos y no todas las demás fueron abiertas.

Entre estas reformas también se dio por terminado el sistema de unir en una persona los mandos civil y militar, salvo en forma transitoria y en caso de extrema urgencia. La necesidad de obtener la confirmación del Senado para poder nombrar oficiales del ejército en cargos civiles restringió los poderes del Ejecutivo para nombrar demasiados militares. Sin embargo, entre los mandos civil y admi- nistrativo el índice de la falta de empleados calificados lo medía la práctica común de una sola persona ocupando dos cargos. Algunos de los elegidos al Congreso estaban desde antes en otras ramas del gobierno y un número mayor de ellos obtuvo empleos ejecutivos y judiciales después de su elección y, generalmente, el único requisito constitucional era el de suspender cualquier otra ocupación mientras el Congreso estuviera en sesión. Aunque tener más de un cargo no siempre era de agrado para un empleado puesto que no podía devengar simultáneamente dos sueldos completos, en muchos casos, como en el Congreso, se requería una causa legítima para poder dirimirse, o en los del recaudador de impuestos y otros puestos municipales, el servicio público era obligatorio (Bushnell, 1985, p.58).

La escasez de personal calificado y la irregularidad en el pago a los funcionarios del Gobierno afectaba naturalmente tanto al poder Judicial como al Ejecutivo. Se suponía la existencia de una corrupción muy extendida entre los funcionarios de los niveles más bajos y los relatos de los visitantes extranjeros están llenos de anotaciones acerca de la disposición de las autoridades a ejercer poderes arbitrarios. La peor corrupción se encontraba en el servicio de las rentas públicas, donde las tentaciones eran particularmente grandes $y$, en las fuerzas armadas, que no estaban siempre sujetas al control del Vicepresidente (Bushnell, 1985, p.65).

El primer censo de la Nación colombiana, organizado por los 12 lntendentes en el año de 1825, arrojó un total de 2.414.655 habitantes, distribuidos en las 1.274 viceparroquias, I.246 parroquias, I I I villas, 96 ciudades, 230 cantones y 37 provincias de los 12 departamentos. 
Cuadro 10

Censo de 1825

\begin{tabular}{|c|c|c|c|c|c|}
\hline Provincias & Habitantes & Provincias & Habitantes & Provincias & Habitantes \\
\hline Casanare & 19.080 & Margarita & 14.690 & Pichincha & 151.111 \\
\hline Pamplona & 66.126 & Cumaná & 35.174 & Imbabura & 56.818 \\
\hline Socorro & |35.08| & Barcelona & 36.147 & Chimborazo & 123.272 \\
\hline Tunja & 189.682 & Guayana & 16.310 & Cuenca & 76.423 \\
\hline Bogotá & 188.695 & Apure & 22.333 & Loja & 34.471 \\
\hline Neiva & 47.157 & Barinas & 87.179 & Manabí & 17.450 \\
\hline Mariquita & 51.339 & Caracas & 166.966 & Guayaquil & 56.038 \\
\hline Antioquia & 104.253 & Carabobo & 159.874 & & \\
\hline Cartagena & 90.426 & Maracaibo & 25.044 & & \\
\hline Santa Marta & 44.395 & Coro & 21.678 & & \\
\hline Riohacha & 11.925 & Trujillo & 32.551 & & \\
\hline Mompós & 40.180 & Mérida & 41.687 & & \\
\hline Chocó & 17.250 & & & & \\
\hline Popayán & 87.994 & & & & \\
\hline $\begin{array}{l}\text { Buenaventu- } \\
\text { ra }\end{array}$ & 18.336 & & & & \\
\hline Pasto & 27.435 & & & & \\
\hline Panamá & 66.119 & & & & \\
\hline Veraguas & 33.966 & & & & \\
\hline TOTALES & 1.239 .439 & & 659.633 & & 515.583 \\
\hline
\end{tabular}

El número de esclavos fue calculado en 103.892 y el de indígenas errantes en los bosques y montañas en 103.835. Hasta la fecha habían sido expedidas 193 cartas de naturalización a extranjeros. El grupo eclesiástico secular estaba compuesto por dos obispos en ejercicio, 94 prebendados, 60 capellanes de coro, 892 curas propietarios, 67 sacristanes mayores, 363 capellanes sueltos o curas interinos y 216 clérigos de órdenes menores. El clero regular, dependiente de los vicarios de Madrid, de las órdenes de franciscanos, dominicos, agustinos calzados y descalzos, mercedarios, hospitalarios de San Juan de Dios y bethlemitas, eran 9.456 religiosos sacerdotes y 432 novi- cios y legos que habitaban en 5 I conventos. Las monjas habitaban 33 conventos en los que fueron contadas 750 religiosas profesas $y$ I.436 novicias, educandas y sirvientas.

Hasta entonces no se mostraba inclinación alguna hacia la descentralización, pues el único compromiso con los federalistas fue la creación en 1825 de las Juntas provinciales o Asambleas cuyos miembros salían de los colegios electorales y que deberían reunirse una vez al año para proponer la legislación necesaria e informar a las autoridades acerca de la situación en la provincia (Bushnell, 1985, p.49).

Las primeras elecciones constitucionales se realizaron el sábado I de octubre de 1825. La polémica sobre el modo como se había contratado y distribuido el empréstito de 1824 desempeñó en estos resultados un importante papel. Al mismo tiempo, se había despertado en ciertos sectores del centro-occidente de Venezuela un sentimiento de frustración por verse gobernados desde Bogotá, en tanto que entre los funcionarios civiles y los intelectuales de Nueva Granada se veía con aprensión la posición preponderante que en las Fuerzas Armadas habían alcanzado muchos venezolanos. En el Ecuador, que permanecía más tranquilo, existía descontento entre los dueños de obrajes, cuyos tejidos sufrían la competencia en precio y calidad que les hacían los importados de Inglaterra, y un malestar económico generalizado debido a que aquella región había costeado en una alta proporción los gastos del ejército grancolombiano libertador del Perú. En el ámbito político, muy pocos eran los nativos del Ecuador que ocupasen posiciones de alguna importancia en el Gobierno central.

El general Bolívar obtuvo una votación unánime en 31 de las 36 
asambleas electorales de las provincias, sumando 582 votos de los 608 emitidos entre todas las Asambleas Electorales. El Libertador fue reelegido Presidente al haber obtenido más de las dos terceras partes de la votación. Solamente en Margarita y Veragua no obtuvo voto alguno. El general José Antonio Páez consiguió I I votos en la provincias de Margarita (7) y Carabobo (4). El general Santander obtuvo todos los 10 votos de la provincia de Veraguas, el general Antonio José de Sucre consiguió 4 votos en la isla de Margarita y en Barinas y el general Rafael Urdaneta un voto en su provincia natal de Maracaibo.

La elección del Vicepresidente fue más reñida. De los 612 votos emitidos en las 36 Asambleas Electorales de provincias, el general Santander obtuvo 286, Pedro Briceño Méndez 78, José María del Castillo y Rada 57, Luis A. Baralt 50, Antonio José de Sucre 38 y los otros candidatos 105 votos. Según el artículo 73 de la Constitución establecía que si ninguno de los tres primeros candidatos obtenía las dos terceras partes, correspondía al Congreso proceder a la escogencia. El artículo 74 decía que si ninguno de los tres obtenía las dos terceras partes se repetiría la elección con los dos de mayor votación. De este modo fue elegido Vicepresidente el general Francisco de Paula Santander con 70 votos, seguido del doctor Castillo y Rada con 22 y el doctor Briceño Méndez con 6.

La crisis política generada por el pronunciamiento de Valencia del 30 de abril de 1826 impidió el quorum requerido en la sesión que daría posesión al Ejecutivo recién elegido. Para poder reunir el quorum, tuvo el Congreso que reunirse en Tunja donde permanecía el senador enfermo con el que se completarían los 25 necesarios para dar posesión al Presidente y Vicepresidente y dar así por instalada la legislatura el 2 de mayo de 1826.

\section{Período de afirmación de la autonomía regional 1826-1830}

Ya desde los primeros meses de 1826, el decaimiento de los ingresos de aduana podría atribuirse al estado del comercio exterior. El 18 de abril de 1826 se efectúa la segunda reforma fiscal. Los ajustes centrales se resumen en la creación de las Direcciones de Tesorería, Tabacos y Aduanas. Proponía ante el Senado el Secretario de Hacienda en ese mismo año modificar el sistema de recaudo a través de los llamados "colectores" de impuestos a los que sin titubeos acusó como negligentes ante la verdadera magnitud de corrupción y fraude al Tesoro público.

La Ley autorizó a los directores de Casas de Moneda imponer arrestos hasta por tres días si sus funcionarios no prestaban un buen servicio. El celo por el cumplimiento de la jornada laboral, llevó a que la ley ordenara a los jefes de las oficinas de hacienda, imponer a los empleados incumplidos jornadas adicionales de trabajo para compensar las horas no laboradas o el descuento de este tiempo en sus salarios (López Garavito, 1992, p.41).

También se promulga una nueva ley con el propósito de agilizar los procedimientos legales para castigar a los ladrones, la que realmente, tampoco puso fin a los robos. El mismo secretario Restrepo se quejó del escaso número de penas capitales que resultaron de esta ley, sin embargo, tal acción representó un factor aparente que ayudó a controlar la criminalidad de la posguerra (Bushnell, 1985, p.72).

Pero para colmo de males surge la exorbitancia de los costos por la Campaña del Perú, la rebelión separatista del 30 de abril de 1826 comandada por el general Páez en las municipalidades venezolanas

Samuel Leónidas Pérez Grau 
de Valencia y Caracas, que pasó a la historia con el nombre de La Cosiata (cosa sin importancia) y, la depresión financiera europea de 1825-1826 de la cual se desprende el colapso en ese mismo año de la firma Goldschmidt, a la sazón el principal prestamista de Colombia.

Entre el 22 de junio y el 15 de julio de 1826, se reunió en Panamá el Congreso Anfictiónico, el cual fue, a la vez, la culminación del máximo sueño de Bolívar y el comienzo de su fracaso. Esta magna asamblea debía fundamentar una gran Nación que, por extensión, población y riquezas naturales jugaría un papel de primer orden en el mundo, puso al descubierto todas nuestras debilidades. Frente a la gran capacidad visionaria del Libertador, sin duda el hispanoamericano más preclaro de su tiempo, se opuso la cortedad de miras de los grandes latifundistas y comerciantes que buscaban mantener sus derechos y privilegios alcanzados.

La idea de la confederación no implicaba para Bolívar el desconocimiento de las particularidades regionales, las dificultades geográficas y las diferencias económicas. Más bien tenía en mente una Liga o Alianza que fuera política, económica y militar, sin que ello significara la disolución de los gobiernos y repúblicas que le conformaran. Sus gobiernos deberían ser centralistas, a criterio de Bolívar, ya que para él, el federalismo a ultranza fue la causa de la división y fracaso de las primeras repúblicas proclamadas hacia 1810 . Eso sí, el Libertador rechaza tajantemente la idea de sujetarlas bajo un régimen monárquico. Siempre se mantuvo ferozmente republicano, aunque fuera bajo un régimen con libertades recortadas, por temor a la anarquía.

El Congreso de Panamá marcó distancias entre los dos viejos amigos y colaboradores $y$ alrededor de ellos se agruparon los principales dirigentes colombianos. En el discurso del Congreso de Angostura, Bolívar pedía formar una liga de países hispanoamericanos bajo la protección de Gran Bretaña, un senado hereditario que nos salvara de la anarquía de las olas populares y se opusiera a las invasiones contra la jurisdicción y la autoridad de los magistrados. Santander prefería un eventual apoyo de los Estados Unidos, más liberales y democráticos que de la monárquica Inglaterra e invitó a ese país a Panamá, en contra de la opinión de Bolívar. Para finales de 1826, el abismo se volvió insalvable. La Constitución de Bolivia declaraba un presidente que nombrara a su sucesor, con un senado hereditario que evitara los riesgos del sufragio popular, centralista $y$, en la que el Ejecutivo tuviera una clara preponderancia. Por su parte, Santander convirtió la defensa de la Constitución de 182I en la piedra de toque del republicanismo liberal.

\section{El pronunciamiento de Valencia}

Presumiblemente, el provincionalismo innato del denominado Club de Caracas, un grupo de letrados, mercaderes y políticos civiles, haya inspirado la idea de que mientras Bolívar estuviese en el Perú la Presidencia debía ser dada a alguien que pudiera ocuparla en forma efectiva, ya que de lo contrario el Gobierno recaería de nuevo en manos del vicepresidente Santander. Además, con tantos elementos de descontento a la mano, no es raro que el Orinoco se convirtiera en el escenario de actividades de bandidaje intermitentes, de desórdenes raciales y de conspiraciones menores, todo lo cual alcanzó su punto álgido desde el año de 1824, gracias a la impopularidad de la conscripción militar para las etapas finales de la guerra con el Perú. Pero los disturbios más graves tuvieron lugar en Margarita, donde desde entonces se quedó a la espera de otro momento oportuno para una acción directa al tiempo, que apoyando a Páez para la pre- 
sidencia y a Carabaño para la vicepresidencia, en las elecciones de 1825-1826, les significaba un paliativo a sus sentimientos federalistas.

Los caraqueños habían continuado oponiendo resistencia al decreto de reclutamiento de Santander y tras una serie de sucesos, entre ellos varios alzamientos populares, el general José Antonio Páez se declaró en desobediencia el 30 de abril de 1826, asumiendo el gobierno de Venezuela y comprometiéndose a no obedecer órdenes del Gobierno central. En Bogotá, la Cámara de Representantes decidió 38 votos contra 16 que Páez debería ser juzgado ante el Senado por su conducta arbitraria y el Senado con un margen similar aceptó la acusación y decidió proceder a un juicio formal (Bushnel, 1985, p.382).

El ataque realizado contra Páez no se fundaba en su poca clara actividad monarquista, aunque ella no eran un secreto en Bogotá, sino que era más bien un resultado directo de los últimos desarrollos de la controversia sobre las milicias iniciadas en Caracas en 1824 . Santander se apresuró a reemplazar a Páez por el general Escalona, aunque provisionalmente, tras su venida a Bogotá. El Concejo de Valencia expresó su indignación por la separación de Páez del servicio a la vez que se generaron algunos desórdenes en inmediaciones del municipio, cuyo movimiento se extendió rápidamente a las provincias centrales de Venezuela. A partir del mes de mayo un número creciente de concejos municipales y de órganos de opinión de Venezuela comenzaron a declararse en favor de un sistema federalista de gobierno.

Pero la reacción de Bolívar no correspondió por completo a las expectativas de Santander. Bolívar desaprobaba parcialmente el nombramiento de Escalona y lo consideraba como una causa decisiva de la revuelta $y$ en una carta enviada a Sucre le manifiesta que el problema venezolano solamente podría ser resuelto por alguna forma de "transacción amistosa". Bolívar adhería por lo menos en principio a las más importantes teorías liberales en boga, pero igualmente estaba convencido de que el pueblo colombiano no estaba suficientemente preparado para gozar verdaderamente de las instituciones liberales.

A la sazón, Bolívar había aconsejado al Congreso de la Guayana la creación de un Senado vitalicio y consideraba que la Constitución de Cúcuta era realmente demasiado liberal. Bolívar miraba a Páez como una víctima del exceso de liberalismo existente en la América española y en la carta que regañaba a Páez por su rebelión contiene la interesante declaración de que los militares habían sufrido menos a manos de los españoles que a causa de las ingratitudes de los civiles que trataban de "destruir a sus libertadores". Al mismo tiempo en el Ecuador los generales Murgueitio, Juan José Flórez y todos los demás líderes prestaron su apoyo en favor de reformas pero se oponían al verdadero federalismo, pues como el coronel Torres, la primera lealtad de todos ellos era para con Bolívar y eran todos actuales o potenciales defensores de la Constitución Boliviana de 1826. 


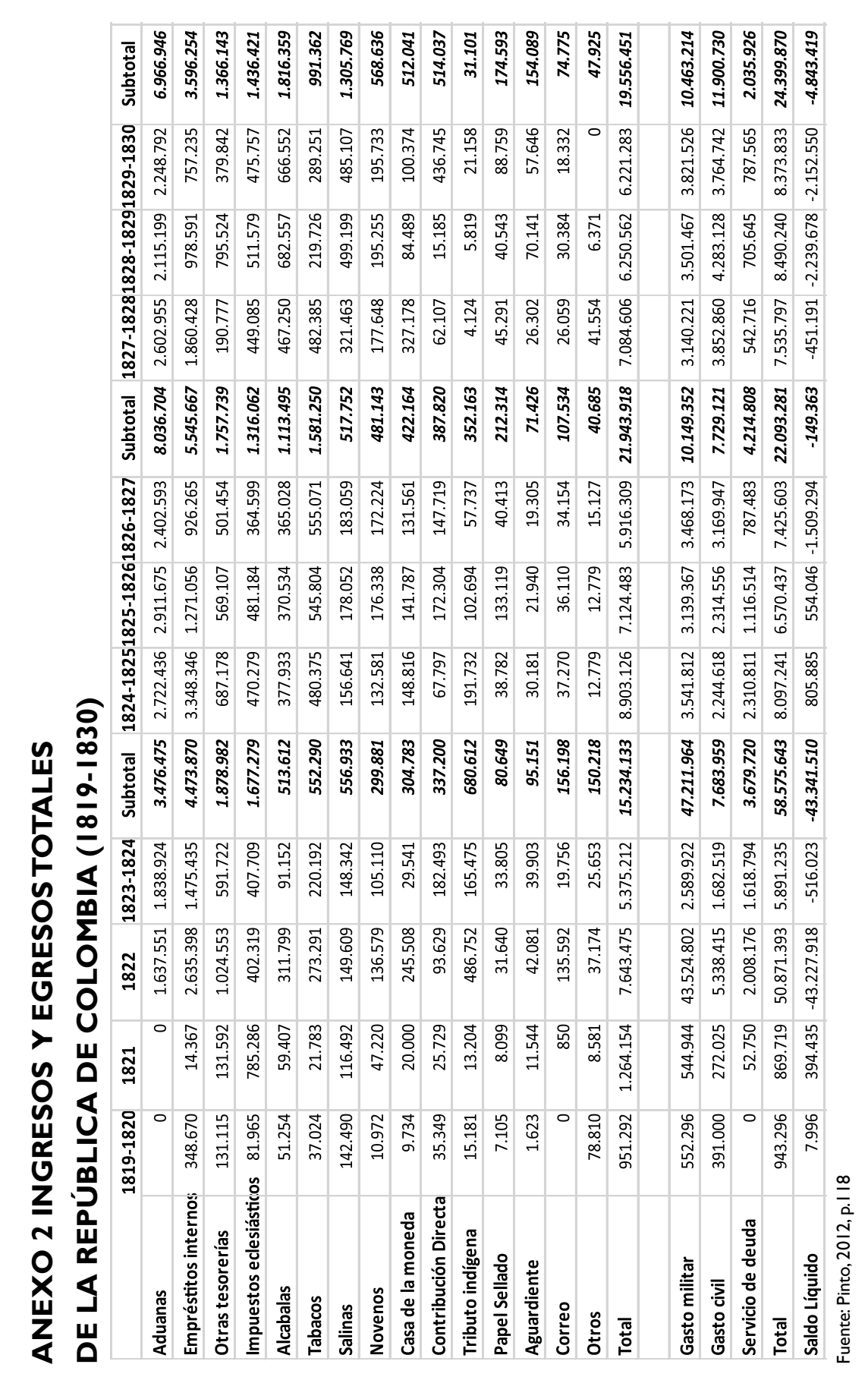

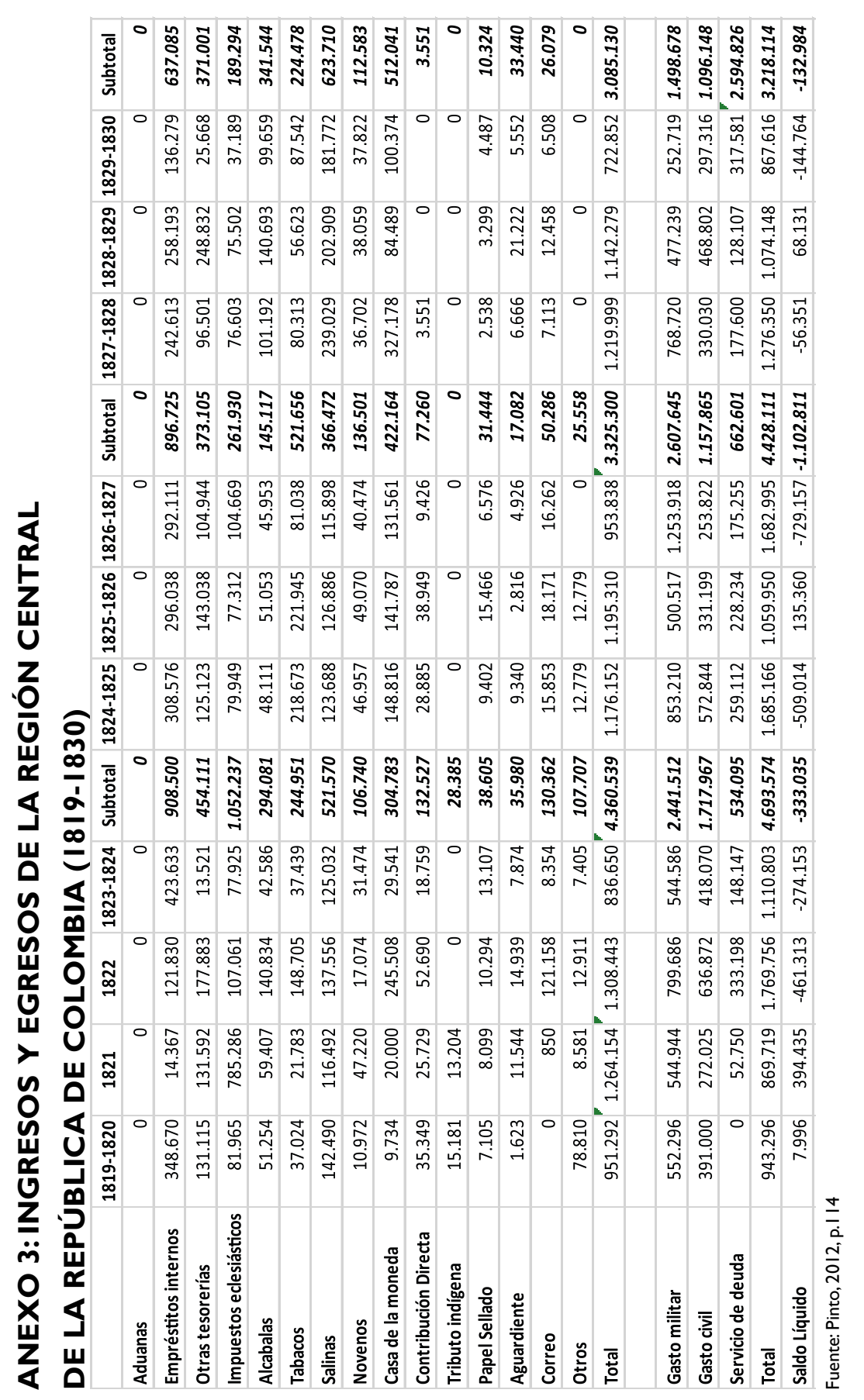




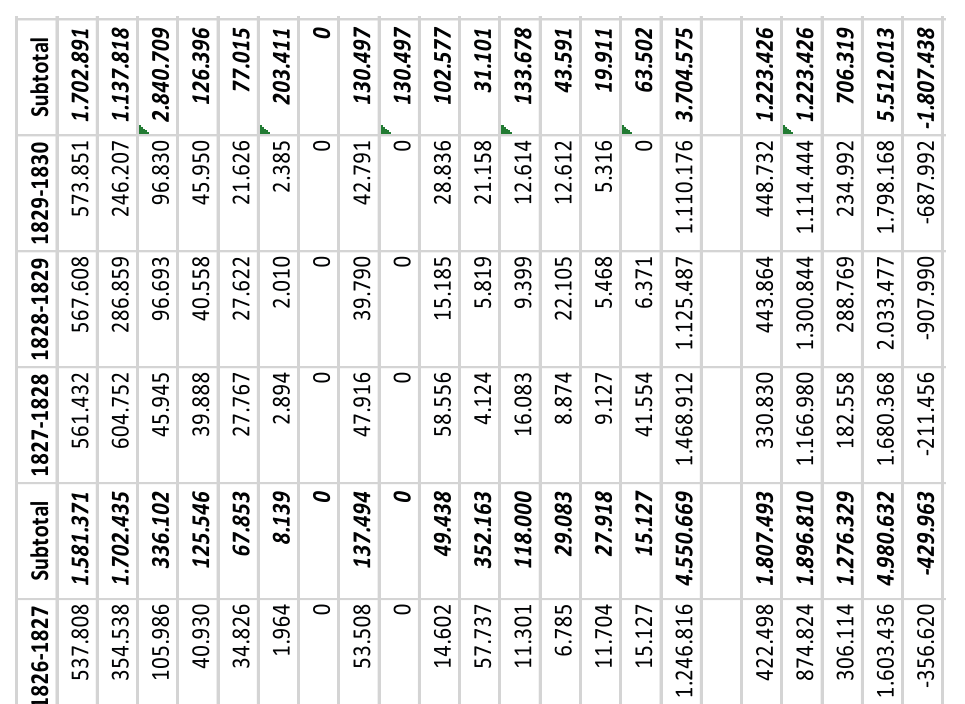

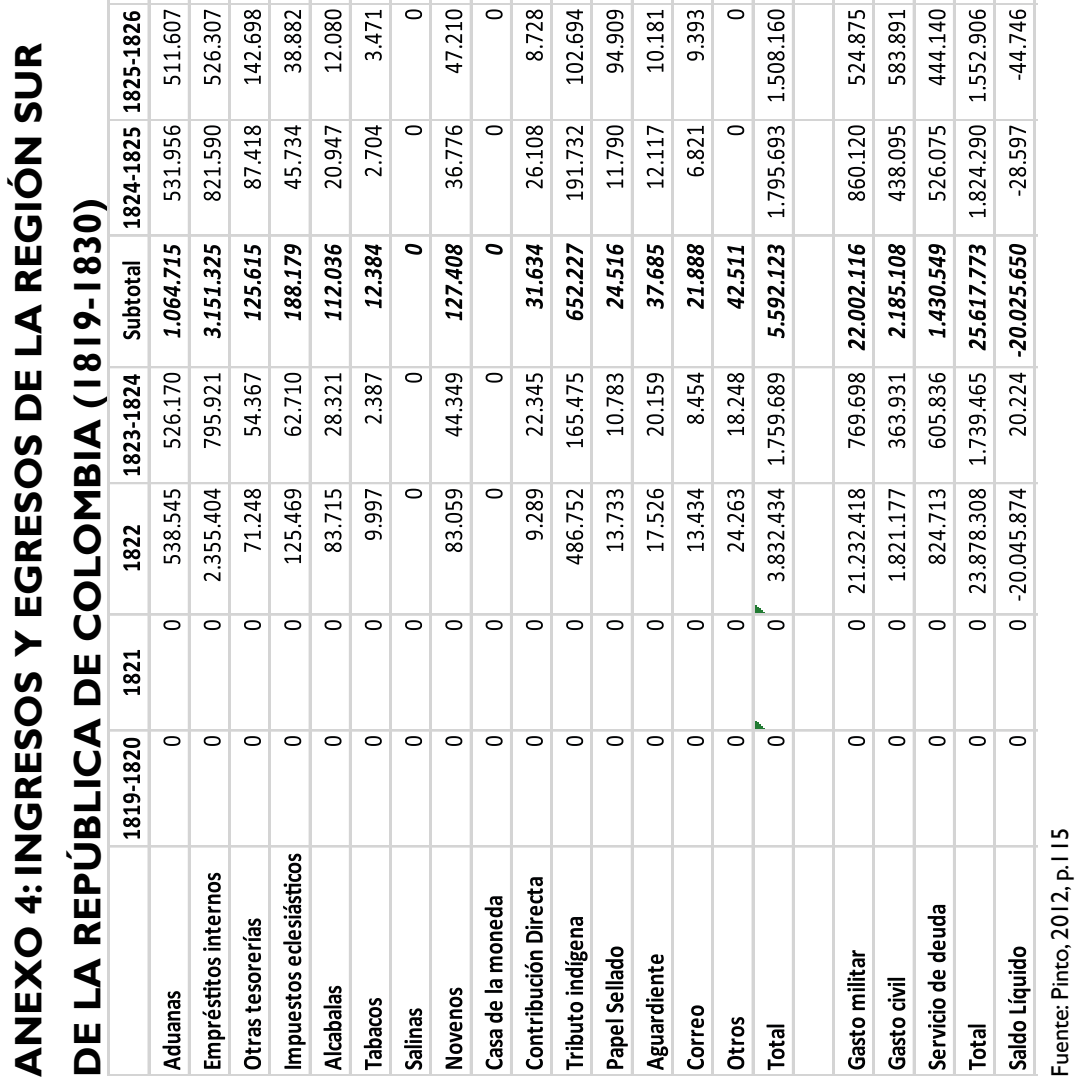

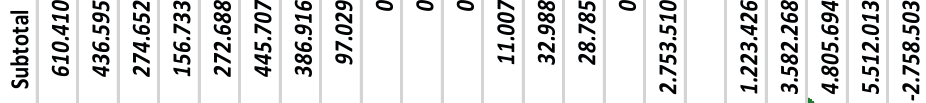

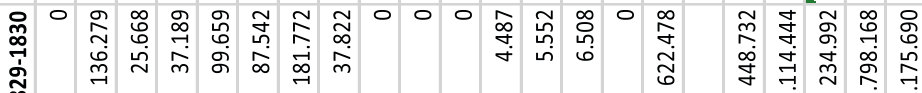

帘

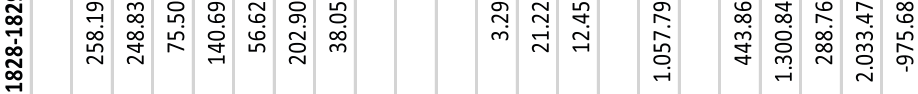

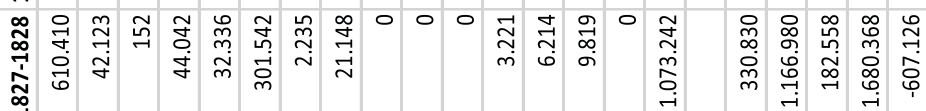

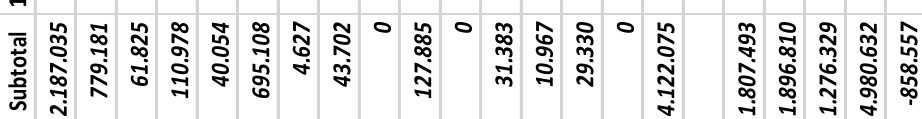

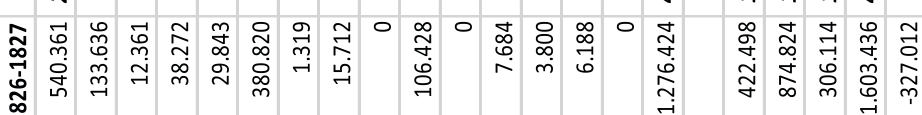

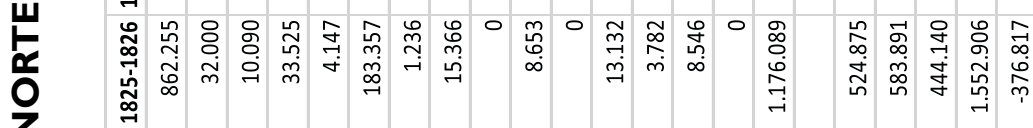

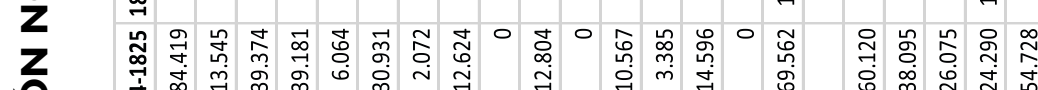

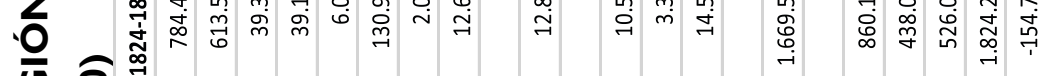

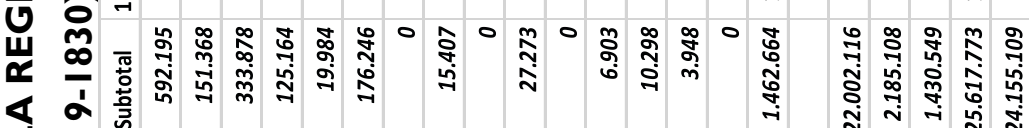

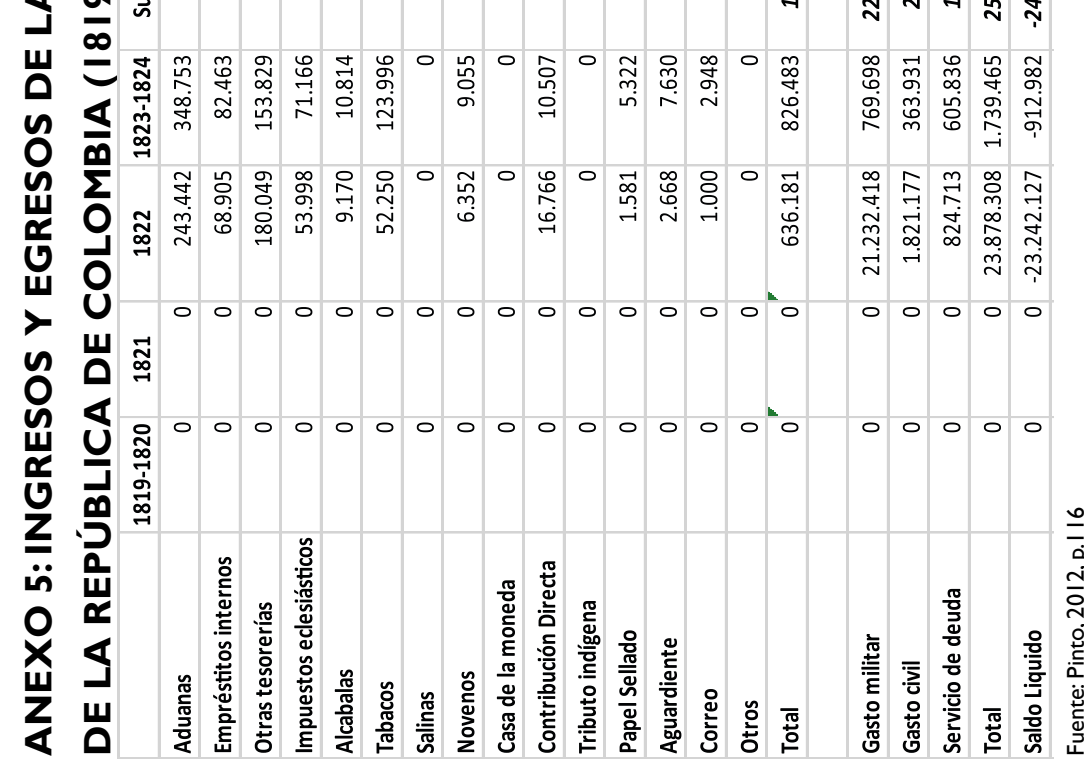




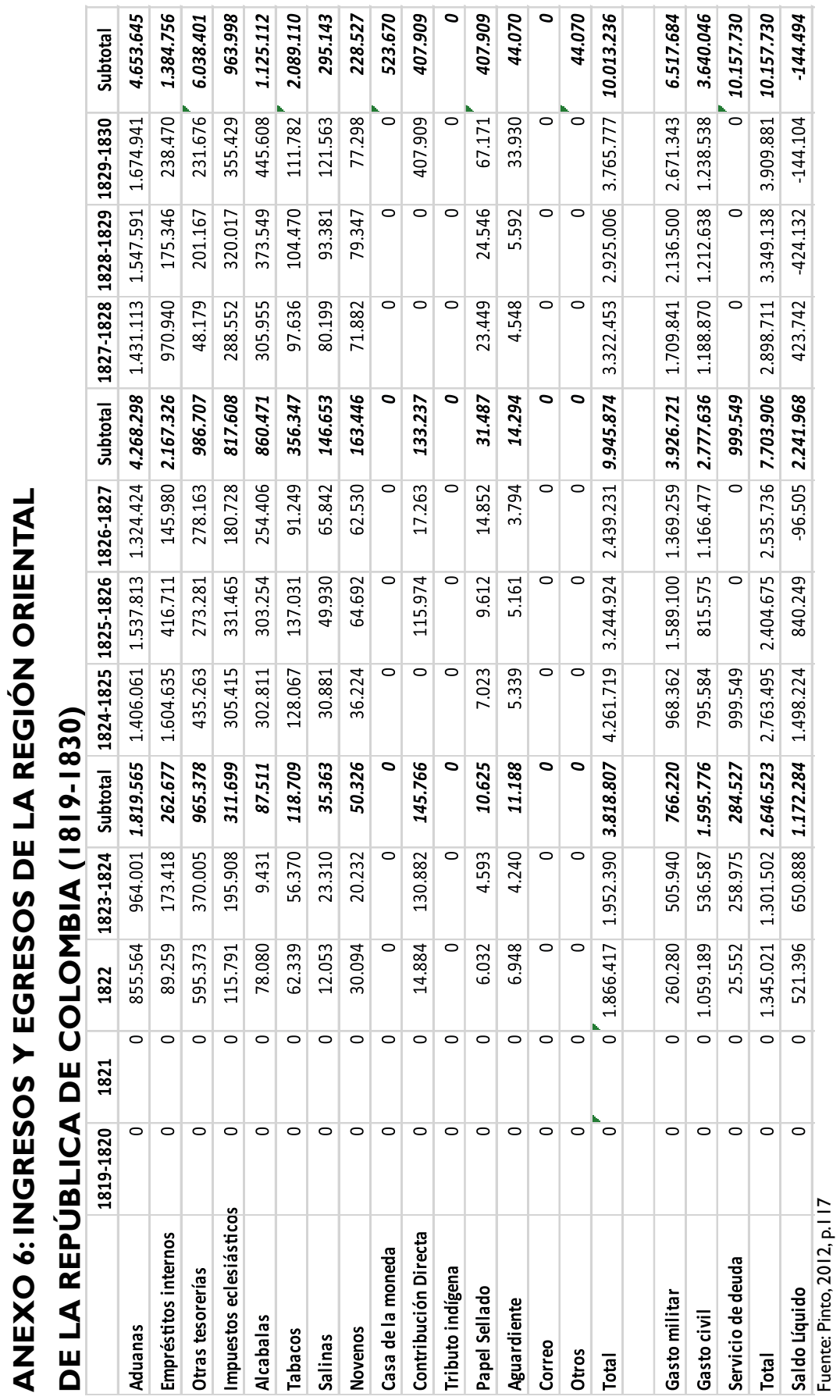

